Review

\title{
A Systematic Review of Campylobacter jejuni Vaccine Candidates for Chickens
}

\author{
Pongthorn Pumtang-on ${ }^{1}\left(\mathbb{D}\right.$, Timothy J. Mahony ${ }^{2} \mathbb{D}$, Rodney A. Hill $^{1} \mathbb{D}$ and Thiru Vanniasinkam ${ }^{1, *}$ \\ 1 School of Biomedical Sciences, Charles Sturt University, Wagga Wagga, NSW 2650, Australia; \\ pongthornp7@gmail.com (P.P.-o.); rhill@csu.edu.au (R.A.H.) \\ 2 Centre for Animal Science, Queensland Alliance for Agriculture and Food Innovation, \\ The University of Queensland, Brisbane, QLD 4072, Australia; t.mahony@uq.edu.au \\ * Correspondence: tvanniasinkam@csu.edu.au; Tel.: +61-2-6933-2669
}

Citation: Pumtang-on, P.; Mahony,

T.J.; Hill, R.A.; Vanniasinkam, T.

A Systematic Review of Campylobacter jejuni Vaccine Candidates for

Chickens. Microorganisms 2021, 9, 397. https://doi.org/10.3390/

microorganisms 9020397

Academic Editor: Nicolae Corcionivoschi

Received: 1 February 2021

Accepted: 11 February 2021

Published: 15 February 2021

Publisher's Note: MDPI stays neutral with regard to jurisdictional claims in published maps and institutional affiliations.

Copyright: (c) 2021 by the authors. Licensee MDPI, Basel, Switzerland. This article is an open access article distributed under the terms and conditions of the Creative Commons Attribution (CC BY) license (https:// creativecommons.org/licenses/by/ $4.0 /)$.

\begin{abstract}
Campylobacter jejuni infection linked to the consumption of contaminated poultry products is one of the leading causes of human enteric illness worldwide. Vaccination of chickens is one of the potential strategies that could be used to control C. jejuni colonization. To date, various C. jejuni vaccines using potential antigens have been evaluated, but a challenge in identifying the most effective formulation is the wide variability in vaccine efficacies reported. A systematic review was undertaken to compare C. jejuni vaccine studies. Based upon specific selection criteria eligible papers were identified and included in the analysis. Vaccine efficacy reported from different $C$. jejuni antigens, vaccine types, and vaccination regimens reported in these papers were reviewed. Our analysis shows that total outer membrane proteins and cysteine $\mathrm{ABC}$ transporter substrate-binding protein were among the most efficacious vaccine antigen candidates reported. This review also highlights the importance of the need for increased consistency in the way $C$. jejuni vaccine studies in poultry are designed and reported in order to be able to undertake a robust comparison of $C$. jejuni vaccine candidates.
\end{abstract}

Keywords: Campylobacter jejuni; vaccination; poultry; chickens; systematic review

\section{Introduction}

Campylobacter jejuni is considered an important zoonotic pathogen causing enteric illness in humans globally [1-3]. Outbreaks are commonly linked to the consumption of contaminated poultry products [4-6]. Poultry is considered a reservoir host of C. jejuni because this pathogen commensally colonizes the intestines where it can be present in large bacterial loads [7]. Based on quantitative risk assessment and regression models in previous studies, a low C. jejuni prevalence (a percentage/proportion of colonized chickens in a flock) between chicken flocks or a 1 to $2 \log 10$ reduction of $C$. jejuni loads in broiler intestines could lead to a decrease in public health risk [8-10]. Thus, both the reduction in C. jejuni concentration and prevention of campylobacter colonization of chickens on farms are the most effective approaches to reduce the risk of campylobacter contamination of chicken meat [9]. To date, researchers have endeavored to develop and evaluate several interventions in primary broiler production including biosecurity monitoring [11], use of feed additives [12-14], drinking water sanitation [15], use of bacteriophage [16], probiotics [17,18], and bacteriocins [19]. Although some of these interventions have led to significant reductions in C. jejuni loads in the intestines of chickens, none of them have eliminated or prevented C. jejuni colonization of poultry.

Vaccination has been considered a potentially effective intervention for controlling C. jejuni colonization of chickens. In recent decades, C. jejuni has been extensively studied, with various prototype vaccines containing potential C. jejuni antigens being evaluated [20-30]. While these studies have typically reported that the prototype vaccines have elicited strong immunogen specific immune responses, they have concurrently reported variable outcomes 
with respect to vaccine efficacy. Typically, these vaccine efficacies would be insufficient in reducing C. jejuni concentration in gut samples and/or preventing colonization. As a consequence, vaccines to prevent $C$. jejuni colonization of chickens are yet to become commercially available.

This review aimed to summarize published studies on vaccines to prevent C. jejuni colonization in chickens using a systematic review approach and identify vaccine antigens most suitable for further development.

\section{Materials and Methods}

A systemic review was carried out according to the guidelines of the Preferred Reporting Items for Systematic Reviews and Meta-Analyzes (PRISMA) [31]. The following research questions were considered in this review.

Key research questions:

1. What antigens have been identified for use in potential vaccine candidates to prevent C. jejuni colonization in chickens?

2. What are the most efficacious $C$. jejuni vaccine candidates in chickens identified?

\subsection{Search Strategy (Literature Search Strategies/Identifying Data Source)}

2.1.1. Databases Searched

Three electronic databases, PubMed Central, Scopus, and Elsevier ScienceDirect, were searched to identify relevant studies for this review.

\subsubsection{Keywords Used in the Search}

The search was performed on January 4, 2021, using the following terms: "Campylobacter" AND "Vaccine" AND "Chicken" (Table 1). All research articles were restricted to English language only, all fields, and were previously published until 2020 (31 December).

Table 1. The algorithm of systematic search terminology.

\begin{tabular}{cc}
\hline Database & Term Search Outcome \\
\hline PubMed Central & “Campylobacter”[All Fields] AND “Vaccine”[All Fields] AND “Chicken”[All Fields] AND \\
$($ “1970/01/01”[PDat]: “2020/12/31”[PDat]) \\
\hline Elsevier ScienceDirect & “Campylobacter” AND “Vaccine” AND “Chicken” \\
\hline TITLE-ABS-KEY (“Campylobacter” AND “Vaccine” AND “Chicken”) AND (LIMIT-TO \\
(PUBYEAR, 2020) OR LIMIT-TO (PUBYEAR, 2019) OR LIMIT-TO (PUBYEAR, 2018) OR \\
LIMIT-TO (PUBYEAR, 2017) OR LIMIT-TO (PUBYEAR, 2016) OR LIMIT-TO (PUBYEAR, 2015) \\
OR LIMIT-TO (PUBYEAR, 2014) OR LIMIT-TO (PUBYEAR, 2013) OR LIMIT-TO (PUBYEAR, \\
2012) OR LIMIT-TO (PUBYEAR, 2010) OR LIMIT-TO (PUBYEAR, 2009) OR LIMIT-TO \\
(PUBYEAR, 2008) OR LIMIT-TO (PUBYEAR, 2007) OR LIMIT-TO (PUBYEAR, 2006) OR \\
LIMIT-TO (PUBYEAR, 2005) OR LIMIT-TO (PUBYEAR, 2004) OR LIMIT-TO (PUBYEAR, 2003) \\
OR LIMIT-TO (PUBYEAR, 2002) OR LIMIT-TO (PUBYEAR, 2001) OR LIMIT-TO (PUBYEAR, \\
2000) OR LIMIT-TO (PUBYEAR, 1999) OR LIMIT-TO (PUBYEAR, 1998) OR LIMIT-TO \\
(PUBYEAR, 1997) OR LIMIT-TO (PUBYEAR, 1996) OR LIMIT-TO (PUBYEAR, 1995) OR \\
LIMIT-TO (PUBYEAR, 1994) OR LIMIT-TO (PUBYEAR, 1993) OR LIMIT-TO (PUBYEAR, 1992) \\
OR LIMIT-TO (PUBYEAR, 1991) OR LIMIT-TO (PUBYEAR, 1990) OR LIMIT-TO (PUBYEAR, \\
1989) OR LIMIT-TO (PUBYEAR, 1988) OR LIMIT-TO (PUBYEAR, 1987) OR LIMIT-TO \\
(PUBYEAR, 1986) OR LIMIT-TO (PUBYEAR, 1985) OR LIMIT-TO (PUBYEAR, 1984) OR \\
LIMIT-TO (PUBYEAR, 1983) OR LIMIT-TO (PUBYEAR, 1982) OR LIMIT-TO (PUBYEAR, 1981) \\
OR LIMIT-TO (PUBYEAR, 1980) OR LIMIT-TO (PUBYEAR, 1979) OR LIMIT-TO (PUBYEAR, \\
1978) OR LIMIT-TO (PUBYEAR, 1977) OR LIMIT-TO (PUBYEAR, 1976) OR LIMIT-TO \\
(PUBYEAR, 1975) OR LIMIT-TO (PUBYEAR, 1974) OR LIMIT-TO (PUBYEAR, 1973) OR \\
LIMIT-TO (PUBYEAR, 1972) OR LIMIT-TO (PUBYEAR, 1971) OR LIMIT-TO (PUBYEAR, 1970)) \\
\hline
\end{tabular}

\subsection{Selection Criteria}

Eligibility of studies for inclusion in this review was determined using a two-step process (primary and secondary inclusion/exclusion criteria) (Table 2). 
Table 2. Inclusion and exclusion criteria in this study.

\begin{tabular}{|c|c|c|}
\hline Process & Inclusion Criteria & Exclusion Criteria \\
\hline Screening & $\begin{array}{c}\text { Primary: } \\
\text { 1. Vaccine studies conducted in chickens } \\
\text { 2. Primary research studies containing vaccinated } \\
\text { and unvaccinated groups } 1 \\
\text { 3. Information of vaccines and vaccination protocols } \\
\text { provided (vaccine formulas, antigen candidate, } \\
\text { vaccine dosage, number of vaccination, route of } \\
\text { vaccine administration, age of chickens or } \\
\text { embryonic eggs when vaccination, challenge strain, } \\
\text { age of chickens at the challenge, sample size, and } \\
\text { chicken breed) } \\
\text { 4. Evaluation and data of vaccine efficacy provided } \\
\text { 5. English language }\end{array}$ & $\begin{array}{c}\text { Primary: } \\
\text { 1. Review articles and guidelines } \\
\text { 2. Non-vaccine studies, non-challenge studies, or } \\
\text { in vitro studies } \\
\text { 3. Non-chicken model studies } \\
\text { 4. Non-Campylobacter vaccine studies } \\
\text { 5. Non-English language } \\
\text { 6. No author name provided } \\
\text { 7. Unable to access the full text of papers }\end{array}$ \\
\hline
\end{tabular}

1. Vaccines conducted in layer chickens

Secondary:

1. Vaccine studies conducted in broiler chickens 2. Studies described the levels of $C$. jejuni loads in Eligibility cecal contents (log10 CFU/gram or CFU/gram) and/or numbers of the individual (colonized ${ }^{2}$ and non-colonized ${ }^{3}$ ) broiler chickens after vaccinations and challenge
2. Co-administration studies other than vaccine studies

2. Studies evaluated immune response alone without an effect of C. jejuni colonization after challenge

3. Studies evaluated the adjuvant efficacy alone or non-C. jejuni antigens

4. Studies evaluated vaccine efficacy using samples other than ceca (i.e., ileum and cloaca)

5. Studies conducted in some challenged chickens after vaccination (defined as a seeder-bird colonization model)

6. Studies that were unable to estimate C. jejuni loads and/or the number of colonized broilers from figures

\begin{abstract}
1 The non-vaccinated (control) groups were defined as the groups of chickens that were conducted in the same vaccine regimen, compared with the vaccinated groups, but administrated with placebo, adjuvants only, parent vectored vaccines, or parent plasmids (without any inserts) ${ }^{2}$ Colonized chickens in this study were defined by detecting or enumerating C. jejuni from cecal samples collected using assays in the original studies. ${ }^{3}$ Non-colonized chickens were defined when the C. jejuni was unculturable or below the detection level of the assays in study samples.
\end{abstract}

Vaccine trials using layers were excluded in this review due to reported differences in C. jejuni colonization and immune responses between layer and broiler chicken breeds [32,33] and an expectation of reducing the public health risk [9,34]. If more than one sample type (i.e., ceca and cloaca) were evaluated in a single study, the result for the cecal sample was selected for the purposes of this study [30]. In applying this, we have not differentiated trials using conventional (bacterial culture) and/or molecular techniques (i.e., qPCR) to determine the colonization status of chickens at the end of vaccination studies [35,36]. Previous studies reported that both bacterial culture and qPCR methods had a high correlation (>99\%) for enumerating C. jejuni in intestinal samples [22] and no significant difference in the detection of Campylobacter in chicken faecal samples [37]. Studies where the required details for the vaccine efficacy data were not provided in a usable format, the author (P.P.) contacted the study corresponding author of the original articles requesting the missing data via email two times. None of the corresponding authors responded to these requests.

Defining Vaccine Efficacy for Selecting Eligible Studies for This Review

The effectiveness of various C. jejuni controlling interventions at broiler farms is commonly evaluated using reduction levels in the prevalence of colonized chickens in a flock and/or reductions of C. jejuni loads in the broiler intestine at slaughterhouse [9]. Previous studies, EFSA [9] and Rosenquist et al. [34] have reported that a decrease in the prevalence of $C$. jejuni between and within broiler flocks could reduce bacterial loads in carcasses at slaughter and consequently reduce the incidence of human campylobacteriosis. Moreover, Nauta et al. [10] reported that a 1-2 log reduction in C. jejuni loads in gut 
contents had an impact on the human health risk of campylobacteriosis with a relative risk reduction by at least $44 \%$ based on regression and risk assessment models. Therefore, articles reporting vaccine efficacy based upon prevalence or proportion of "diseased" (i.e., colonized) chickens in a flock or group [38] and/or the reduction levels of C. jejuni colonization in vaccinated and unvaccinated chicken groups after $C$. jejuni challenge, were included in this review.

\subsection{Data Extraction}

All research articles identified from the three databases were entered in Microsoft Excel datasheets and duplicate studies were removed by one author (P.P.). One author (P.P.) initially inspected the titles and abstracts from the individual articles to select articles for inclusion in the review. If those titles and abstracts fitted the selection criteria, the full text of each potential article was further examined for the final determinations of eligible studies. At this stage, the full text was reviewed to classify the eligible studies and trials based on the vaccine-controlled efficacy trials described and to extract the relevant information. Subsequently, another independent reviewer (T.V.) validated the data and results. For any disagreements, all conflicts were resolved by consensus, and a third author (T.J.M. or R.A.H.) was asked to confirm whether the articles should be included or excluded. The final lists of the eligible article were imported to the EndnoteX9 program for storage, and consolidation (P.P.).

The extracted information of the individual eligible studies included article identification (authors and publication year), the title of each article, study type, information of animal models (poultry species), vaccine types, vaccine regimen (dosages of vaccine and adjuvants, ages of chickens, antigen candidates, frequency of vaccination, and bacterial challenge strains), samples collected, isolation test and outcome measurements of vaccine efficacy between the vaccinated and unvaccinated groups at the end of study. The concentration of C. jejuni loads in cecal contents and/or reduction levels of C. jejuni colonization reported in text and tabulation and/or estimated from figures provided in the original papers were included in this review. For multiple trials reported in each paper, each trial was considered as a separate trial unless the trials using the same vaccine protocols and evaluation methods. If only one control group was used to compare with more than one type of vaccine in the same experiment, this control group was used for each comparison. If two control groups were used in the DNA vaccine study, one control group with the parent plasmids (no insertion of an antigen of interest) was used as the control group [39]. The extracted information was summarized in Microsoft Excel datasheets.

\subsection{Data Analysis}

The extracted data were analysed with the aim of conducting a systematic review and/or meta-analysis. Based on the data extracted using a definition of prevalence detected in vaccinated broilers, six eligible articles (18 trials) reporting different C. jejuni antigens, vaccine types, and vaccine protocols were identified. Consequently, it was possible to undertake a systematic review, but the data were insufficient to conduct a meta-analysis. The outcomes of individual vaccine trials of the eligible studies were extracted, analysed, and reported as a percentage (proportion) of colonized broilers and relative risk (RR) with $95 \%$ confidence interval (CI). Trials with $R R<1.00$ were further analysed with respect to vaccine efficacy as it indicates that the exposed (vaccinated) group could reduce a ratio of the risk or possibility of disease (C. jejuni) occurrence, compared to the unexposed (non-vaccinated) group [40]. While trials with $R R$ is $\geq 1.00$ were reported as having no effect in this review. The efficacy of vaccine was calculated as $(1-R R)$ and reported as a percentage $[39,41,42]$. The R software program (Version 1.3.1056, the R Foundation, Vienna, Austria) was used for calculating these estimates [43].

Trials demonstrating a $\log 10$ reduction of $C$. jejuni loads between vaccinated and non-vaccinated broilers and reporting this as a geometric or arithmetic mean or median 
of $\log 10$ (CFU/gram) loads of each treatment group were included. Extracted data from 62 trials reported in 16 papers were included for this review.

\section{Results}

\subsection{Search Results}

A total of 1556 articles were retrieved from the three electronic databases (PubMed Central, Scopus, and Elsevier ScienceDirect). Of these, 1488 articles (95.6\%) were assessed using the text of the title and abstract after the removal of duplicates. The selection process used in the current study is shown in Figure 1.

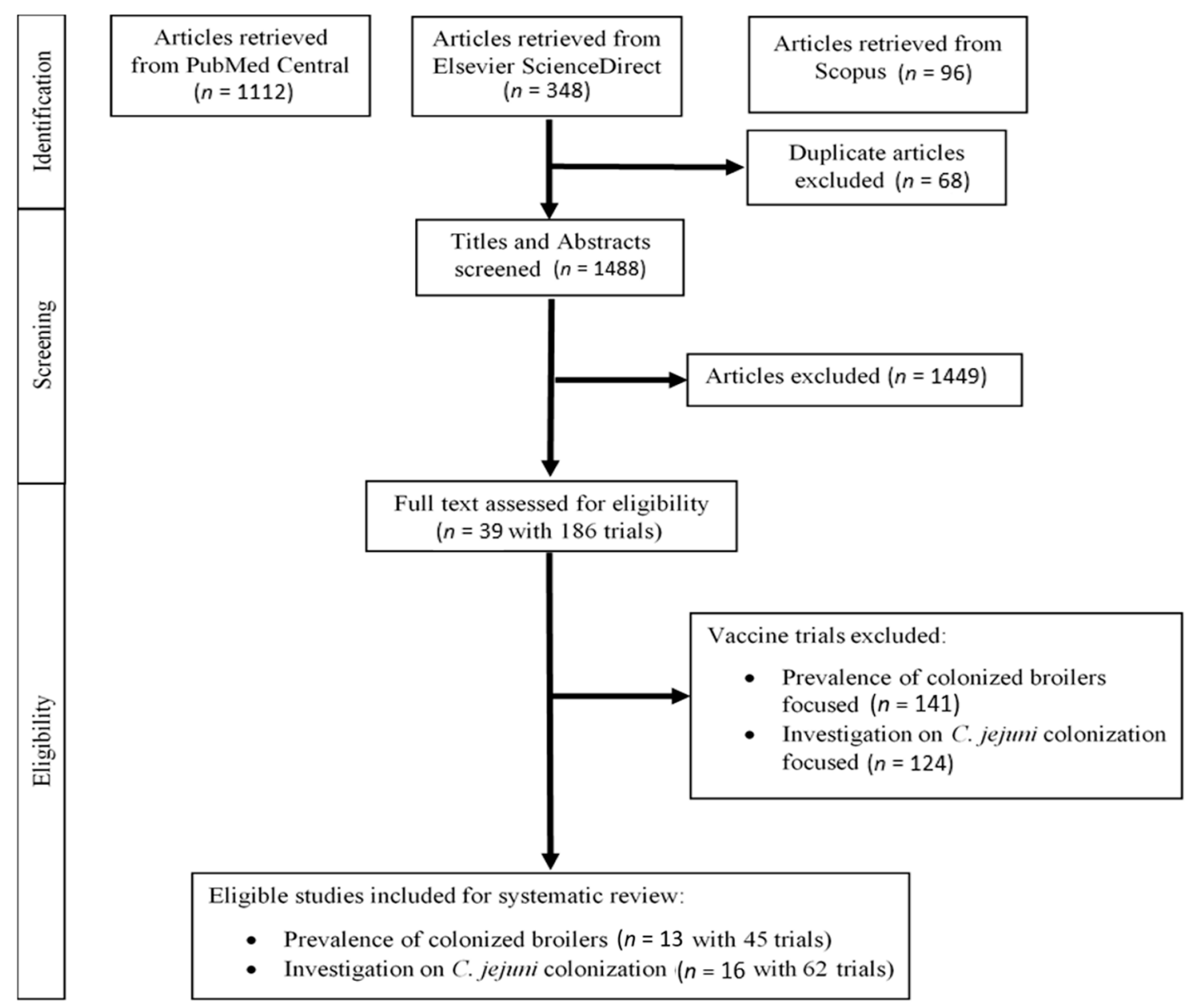

Figure 1. Flow diagram of the selection process to identify articles to be included in the systematic review.

\subsubsection{Screening Process}

Following the screening of titles and abstracts, 1449 articles were excluded (Figure 1). Of the excluded articles, 557 were review articles: 122 (Campylobacter biology, pathogenesis, genes, control and prevention, and vaccines), 95 (human infectious diseases and communicable disease), 78 (antimicrobials and probiotics), 67 (micro-organism: microbial, virus, bacteriophages protozoa and parasites), 49 (bacteria other than Campylobacter), 47 (immunity and antigens), 35 (zoonosis, plant-based, and dietary), 21 (foodborne, waterborne, and food safety), 16 (genetic controls, guidelines of prevention and diagnosis, internal organs, and toxins), 13 (methods and biotechnologies), seven (birds, turkey, ferret, ruminant, and rabbit), six (cancers, chicken gastrointestinal tract, poultry management, taxonomy, and wastewater), and one (no author name provided). A total of 877 primary research studies did not meet the selection criteria: 538 (non-Campylobacter studies), 237 (Campylobacter studies but not vaccines), 85 (non-Campylobacter vaccine studies), and 17 (Campylobacter 
vaccines conducted in non-poultry animals, immunogenicity experiments, and unable to obtain full-text). In addition, 12 and three excluded articles were proceeding abstracts and non-English language, respectively.

\subsubsection{Eligibility}

The remaining 39 articles fulfilled the initial selection criteria for further assessing the full text for eligibility and were published within the search period. From the 37 articles, 186 trials were identified, and these trials involved the evaluation of $C$. jejuni vaccines conducted in chickens (layers and broilers). Of the 186 trials, 66 trials conducted in layer chickens were excluded. Thus, 120 trials conducted in broilers were included for further review using two different focuses of vaccine efficacy (the prevalence of colonized broilers and significant $\log 10$ reduction levels) reported in text/tabulations of the original papers.

Based on the full-text evaluation using the investigation on the $C$. jejuni loads in cecal contents, 58 of 120 vaccine trials in broilers were excluded as they were a seeder colonization challenge model $(n=22)$, immunogenicity studies $(n=18)$, vaccine efficacy evaluated from ileum and cloaca $(n=15)$, trials using co-administration of vaccine and probiotics $(n=2)$, vaccine efficacy reported as prevalence $(n=1)$. Consequently, 62 vaccine trials fulfilled the selection criteria of this review. A summary of the details of these studies is shown in Table 3.

Based on the full-text evaluation using the prevalence of colonized chickens, 75 of 120 trials $(85.0 \%)$ were excluded. The majority of the excluded trials were vaccine trials using a seeder colonization challenge model $(n=22)$, followed by data of number of individual colonized broiler not reported or unable to estimate from figures $(n=18)$, immune responses reported $(n=18)$, vaccine efficacy evaluated from ileum and cloaca ( $n=15 ; 4$ articles) $[22,28,44,45]$, and trials using co-administration of vaccine and probiotics ( $n=2 ; 1$ article) [46]. The remaining 45 trials (10.1\%) from 13 articles fulfilled the selection criteria and were included in the systematic review. 
Table 3. Summary of Campylobacter jejuni vaccine trials in broilers evaluated based on isolation of Campylobacter jejuni from cecal contents.

\begin{tabular}{|c|c|c|c|c|c|c|c|}
\hline \multirow[t]{2}{*}{ Trial No. } & \multirow[t]{2}{*}{$\begin{array}{l}\text { Vaccine Formulations, } \\
\text { Antigens, and Regimens }\end{array}$} & \multirow{2}{*}{$\begin{array}{l}\text { Bacterial Challenge } \\
\text { Strain (Dose (log10 } \\
\text { CFU)) and Day of } \\
\text { Challenge }\end{array}$} & \multirow[t]{2}{*}{$\begin{array}{l}\text { Age of Chickens at } \\
\text { the End of Study } \\
\text { (Days) }\end{array}$} & \multicolumn{2}{|c|}{$\begin{array}{c}\text { Levels of Campylobacter jejuni } \\
\text { Colonization (Mean log10 CFU/gram } 1 \\
\text { and/or } \pm \text { Standard Error of Mean) } \\
\text { Following Challenge }\end{array}$} & \multirow{2}{*}{$\begin{array}{c}\text { Reduction in Levels } \\
\text { (Mean log10 } \\
\text { CFU/gram) of } \\
\text { C. jejuni Coloniza- } \\
\text { tion Reported }^{2}\end{array}$} & \multirow[t]{2}{*}{ Reference } \\
\hline & & & & Vaccinated Broilers & $\begin{array}{l}\text { Non-Vaccinated } \\
\text { Broilers }\end{array}$ & & \\
\hline 1 & $\begin{array}{l}\text { Crude cell lysate vaccine } \\
\text { with } 125 \mu \mathrm{g} \text { of total outer } \\
\text { membrane proteins (OMP) } \\
\text { encapsulated with poly } \\
\text { lactide-co-glycolide } \\
\text { nanoparticles (OMP-NP), } \\
\text { orally with booster }\end{array}$ & $\begin{array}{l}\text { C. jejuni 81-176 (8.0) } \\
\quad \text { and Day } 35\end{array}$ & 42 & $6.3^{3}$ & $6.7^{3}$ & $\begin{array}{l}\text { Non-significant } 0.4 \\
\log 10 \text { reduction }\end{array}$ & Annamalai et al. [47] \\
\hline 2 & $\begin{array}{l}\text { Crude cell lysate vaccine } \\
\text { with } 125 \mu \mathrm{g} \text { of OMP, orally } \\
\text { with booster }\end{array}$ & $\begin{array}{l}\text { C. jejuni 81-176 (8.0) } \\
\text { and Day } 35\end{array}$ & 42 & $5.9^{3}$ & $6.7^{3}$ & $\begin{array}{l}\text { Non-significant } 0.8 \\
\log 10 \text { reduction } 4\end{array}$ & Annamalai et al. [47] \\
\hline 3 & $\begin{array}{c}\text { Crude cell lysate vaccine } \\
\text { with } 125 \mu \mathrm{g} \text { of OMPs-NP, } \\
\text { subcutaneously with booster }\end{array}$ & $\begin{array}{l}\text { C. jejuni 81-176 (8.0) } \\
\quad \text { and Day } 35\end{array}$ & 42 & $\begin{array}{c}<1.00 \text { (below } \\
\text { detection limit) }\end{array}$ & $6.7^{3}$ & $\begin{array}{l}\text { Significant } 5.7 \log 10 \\
\text { reductions }\end{array}$ & Annamalai et al. [47] \\
\hline 4 & $\begin{array}{l}\text { Crude cell lysate vaccine } \\
\text { with } 125 \mu \mathrm{g} \text { of OMP, orally } \\
\text { with booster }\end{array}$ & $\begin{array}{l}\text { C. jejuni } 81-176(8.0) \\
\text { and Day } 35\end{array}$ & 42 & $\begin{array}{c}<1.00 \text { (below } \\
\text { detection limit) }\end{array}$ & $6.7^{3}$ & $\begin{array}{l}\text { Significant } 5.7 \log 10 \\
\text { reductions } \\
4\end{array}$ & Annamalai et al. [47] \\
\hline 5 & $\begin{array}{l}\text { Crude cell lysate vaccine } \\
\text { with } 25 \mu \mathrm{g} \text { of OMP-NP, } \\
\text { subcutaneously with booster }\end{array}$ & $\begin{array}{l}\text { C. jejuni 81-176 (8.0) } \\
\quad \text { and Day } 35\end{array}$ & 42 & $5.5^{3}$ & $6.7^{3}$ & $\begin{array}{l}\text { Non-significant } 1.2 \\
\log 10 \text { reductions }\end{array}$ & Annamalai et al. [47] \\
\hline 6 & $\begin{array}{l}\text { Crude cell lysate vaccine } \\
\text { with } 250 \mu \mathrm{g} \text { of OMP-NP, } \\
\text { orally with booster }\end{array}$ & $\begin{array}{l}\text { C. jejuni } 81-176(8.0) \\
\text { and Day } 35\end{array}$ & 42 & $5.8^{3}$ & $6.7^{3}$ & $\begin{array}{l}\text { Non-significant } 0.9 \\
\log 10 \text { reductions }\end{array}$ & Annamalai et al. [47] \\
\hline 7 & $\begin{array}{l}\text { Crude cell lysate vaccine } \\
\text { with } 25 \mu \mathrm{g} \text { of OMP, orally } \\
\text { with booster }\end{array}$ & $\begin{array}{l}\text { C. jejuni 81-176 (8.0) } \\
\quad \text { and Day } 35\end{array}$ & 42 & $5.1^{3}$ & $6.7^{3}$ & $\begin{array}{l}\text { Non-significant } 1.6 \\
\log 10 \text { reductions } 4\end{array}$ & Annamalai et al. [47] \\
\hline
\end{tabular}


Table 3. Cont.

\begin{tabular}{|c|c|c|c|c|c|c|c|}
\hline Trial No. & $\begin{array}{l}\text { Vaccine Formulations, } \\
\text { Antigens, and Regimens }\end{array}$ & $\begin{array}{l}\text { Bacterial Challenge } \\
\text { Strain (Dose (log10 } \\
\text { CFU)) and Day of } \\
\text { Challenge }\end{array}$ & $\begin{array}{l}\text { Age of Chickens at } \\
\text { the End of Study } \\
\text { (Days) }\end{array}$ & \multicolumn{2}{|c|}{$\begin{array}{c}\text { Levels of Campylobacter jejuni } \\
\text { Colonization (Mean log10 CFU/gram } 1 \\
\text { and/or } \pm \text { Standard Error of Mean) } \\
\text { Following Challenge }\end{array}$} & $\begin{array}{l}\text { Reduction in Levels } \\
\text { (Mean log10 } \\
\text { CFU/gram) of } \\
\text { C. jejuni Coloniza- } \\
\text { tion Reported }^{2}\end{array}$ & Reference \\
\hline 8 & $\begin{array}{l}\text { Crude cell lysate vaccine } \\
\text { with } 250 \mu \mathrm{g} \text { of OMP, orally } \\
\text { with booster }\end{array}$ & $\begin{array}{l}\text { C. jejuni 81-176 (8.0) } \\
\quad \text { and Day } 35\end{array}$ & 42 & $5.7^{3}$ & $6.7^{3}$ & $\begin{array}{l}\text { Non-significant } 1.0 \\
\log 10 \text { reduction }\end{array}$ & Annamalai et al. [47] \\
\hline 9 & $\begin{array}{c}10^{9} \text { CFU of } L \text {. lactis NZ9000 } \\
\text { strain vectored vaccine } \\
\text { expressing C. jejuni } \\
\text { surface-exposed lipoprotein } \\
\text { A (JlpA), intragastrically } \\
\text { with booster }\end{array}$ & $\begin{array}{l}\text { C. jejuni } \mathrm{BCH} 71(9.0) \\
\text { and Day } 28\end{array}$ & 35 & $\begin{array}{c}6.43 \pm 0.107 \text { in } \\
\text { Trial\#1 } \\
8.06 \pm 0.05 \text { in Trial\#2 } \\
9.078 \pm 0.052 \text { in } \\
\text { Trial\#3 }\end{array}$ & $\begin{array}{l}7.22 \pm 0.106 \text { in } \\
\text { Trial\#1 } \\
8.53 \pm 0.089 \text { in } \\
\text { Trial\#2 } \\
9.56 \pm 0.075 \text { in } \\
\text { Trial\#3 } \\
\end{array}$ & $\begin{array}{c}\text { Significant } 0.79 \log 10 \\
\text { reduction in Trial\#1 } \\
\text { Significant } 0.47 \log 10 \\
\text { reduction in \#2 } \\
\text { Significant } 0.482 \\
\log 10 \text { reduction in \#3 }\end{array}$ & Gorain et al. [48] \\
\hline 10 & $\begin{array}{l}\text { Subunit vaccine with } 50 \mu \mathrm{g} \\
\text { of recombinant JlpA } \\
\text { emulsified in Freund's } \\
\text { incomplete adjuvant, } \\
\text { subcutaneously with booster }\end{array}$ & $\begin{array}{l}\text { C. jejuni BCH71 (9.0) } \\
\text { and Day } 28\end{array}$ & 35 & $\begin{array}{c}6.89 \pm 0.091 \text { in } \\
\text { Trial\#1 } \\
7.90 \pm 0.05 \text { in Trial\#2 } \\
9.15 \pm 0.080 \text { in } \\
\text { Trial\#3 }\end{array}$ & $\begin{array}{l}7.00 \pm 0.107 \text { in } \\
\text { Trial\#1 } \\
8.59 \pm 0.069 \text { in } \\
\text { Trial\#2 } \\
9.64 \pm 0.037 \text { in } \\
\text { Trial\#3 } \\
\end{array}$ & $\begin{array}{c}\text { Non-significant } 0.11 \\
\log 10 \text { in Trial\#1 } \\
\text { Significant } 0.69 \log 10 \\
\text { in Trial\#2 } \\
\text { Significant } 0.49 \log 10 \\
\text { in Trial\#3 }\end{array}$ & Gorain et al. [48] \\
\hline 11 & $\begin{array}{c}25 \mu \mathrm{g} \text { of Capsular } \\
\text { polysaccharide conjugated } \\
\text { with diphtheria toxoid of } \\
\text { Corynebacterium diphtheriae } \\
\text { vaccine (CPSconj) mixed } \\
\text { with } 10 \mu \mathrm{g} \text { of CpG ODN } \\
\text { 2007, subcutaneously } \\
\text { with booster }\end{array}$ & $\begin{array}{c}\text { C. jejuni 81-176 (7.3) } \\
\text { and Day } 28\end{array}$ & 38 & $7.55 \pm 0.15$ & $8.11 \pm 0.15$ & $\begin{array}{l}\text { Significant } 0.56 \log 10 \\
\text { reduction }\end{array}$ & Hodgins et al. [49] \\
\hline 12 & $\begin{array}{c}25 \mu g \text { of CPSconj mixed with } \\
100 \mu \mathrm{L} \text { of Addavax, } \\
\text { subcutaneously with booster }\end{array}$ & $\begin{array}{l}\text { C. jejuni 81-176 (7.3) } \\
\text { and Day } 28\end{array}$ & 38 & $7.47 \pm 0.14$ & $8.11 \pm 0.15$ & $\begin{array}{l}\text { Significant } 0.64 \log 10 \\
\text { redcution } 5\end{array}$ & Hodgins et al. [49] \\
\hline
\end{tabular}


Table 3. Cont.

\begin{tabular}{|c|c|c|c|c|c|c|c|}
\hline Trial No. & $\begin{array}{l}\text { Vaccine Formulations, } \\
\text { Antigens, and Regimens }\end{array}$ & $\begin{array}{l}\text { Bacterial Challenge } \\
\text { Strain (Dose (log10 } \\
\text { CFU)) and Day of } \\
\text { Challenge }\end{array}$ & $\begin{array}{l}\text { Age of Chickens at } \\
\text { the End of Study } \\
\text { (Days) }\end{array}$ & \multicolumn{2}{|c|}{$\begin{array}{c}\text { Levels of Campylobacter jejuni } \\
\text { Colonization (Mean log10 CFU/gram } 1 \\
\text { and/or } \pm \text { Standard Error of Mean) } \\
\text { Following Challenge }\end{array}$} & $\begin{array}{c}\text { Reduction in Levels } \\
\text { (Mean log10 } \\
\text { CFU/gram) of } \\
\text { C. jejuni Coloniza- } \\
\text { tion Reported }{ }^{2}\end{array}$ & Reference \\
\hline 13 & $\begin{array}{c}25 \mu \mathrm{g} \text { of CPSconj, } \\
\text { subcutaneously with booster }\end{array}$ & $\begin{array}{l}\text { C. jejuni } 81-176(7.3) \\
\text { and Day } 28\end{array}$ & 38 & $7.38 \pm 0.15$ & $8.11 \pm 0.15$ & $\begin{array}{l}\text { Significant } 0.73 \log 10 \\
\text { reduction }\end{array}$ & Hodgins et al. [49] \\
\hline 14 & $\begin{array}{l}\text { DNA vaccine (prime) with } \\
300 \mu \mathrm{g} \text { of purified DNA of } \\
\text { Campylobacter hemolysin } \\
\text { activation/secretion protein } \\
\text { (YP_001000437.1) cloned into } \\
\text { pcDNA3 plasmids mixed } \\
\text { with } 50 \mu \mathrm{g} \text { of CpG ODN2007 } \\
\text { and subunit vaccine (boost) } \\
\text { with } 100 \mu \mathrm{g} \text { of recombinant } \\
\text { YP_001000437.1 protein } \\
\text { emulsified with } \\
\text { MONTANIDE } \\
\text { intramuscularly with booster }\end{array}$ & $\begin{array}{l}\text { C. jejuni } \\
\text { C97Anses640 (5.0) } \\
\text { and Day } 19\end{array}$ & 42 & $4.41 \pm 2.15$ & $8.02 \pm 1.19$ & $\begin{array}{l}\text { Significant } 3.61 \log 10 \\
\text { reductions upon } \\
\text { heterologous } \\
\text { challenge }\end{array}$ & Meunier et al. [50] \\
\hline 15 & $\begin{array}{l}\text { DNA vaccine (prime) with } \\
300 \mu \mathrm{g} \text { of purified DNA of } \\
\text { YP_001000437.1 cloned into } \\
\text { pcDNA3 plasmids mixed } \\
\text { with } 50 \mu \mathrm{g} \text { of CpG ODN2007 } \\
\text { and subunit vaccine (boost) } \\
\text { with } 100 \mu \mathrm{g} \text { of recombinant } \\
\text { YP_001000437.1 protein } \\
\text { emulsified with } \\
\text { MONTANIDE } \\
\text { intramuscularly with booster }\end{array}$ & $\begin{array}{l}\text { C. jejuni } \\
\text { C97Anses640 (5.0) } \\
\text { and Day } 19\end{array}$ & 42 & $\begin{array}{l}3.53 \pm 1.86 \\
(\mathrm{GenEq} / \mathrm{g})\end{array}$ & $\begin{array}{l}5.45 \pm 2.61 \\
(\mathrm{GenEq} / \mathrm{g})\end{array}$ & $\begin{array}{l}\text { Non-significant } 1.92 \\
\log 10 \text { GenEq/g } \\
\text { reductions upon } \\
\text { heterologous } \\
\text { challenge }\end{array}$ & Meunier et al. [50] \\
\hline
\end{tabular}


Table 3. Cont

\begin{tabular}{|c|c|c|c|c|c|c|c|}
\hline Trial No. & $\begin{array}{l}\text { Vaccine Formulations, } \\
\text { Antigens, and Regimens }\end{array}$ & $\begin{array}{l}\text { Bacterial Challenge } \\
\text { Strain (Dose (log10 } \\
\text { CFU)) and Day of } \\
\text { Challenge }\end{array}$ & $\begin{array}{l}\text { Age of Chickens at } \\
\text { the End of Study } \\
\text { (Days) }\end{array}$ & \multicolumn{2}{|c|}{$\begin{array}{l}\text { Levels of Campylobacter jejuni } \\
\text { Colonization (Mean log10 CFU/gram } 1 \\
\text { and/or } \pm \text { Standard Error of Mean) } \\
\text { Following Challenge }\end{array}$} & $\begin{array}{l}\text { Reduction in Levels } \\
\text { (Mean log10 } \\
\text { CFU/gram) of } \\
\text { C. jejuni Coloniza- } \\
\text { tion Reported }^{2}\end{array}$ & Reference \\
\hline 16 & $\begin{array}{l}\text { DNA vaccine (prime) with } \\
300 \mu \mathrm{g} \text { of purified DNA of } \\
\text { flagellin protein family } \\
\text { (FlgL) cloned into pcDNA3 } \\
\text { plasmids mixed with } 50 \mu \mathrm{g} \\
\text { of CpG ODN2007 and } \\
\text { subunit vaccine (boost) with } \\
100 \mu \mathrm{g} \text { of recombinant FlgL } \\
\text { emulsified with } \\
\text { MONTANIDETM ISA70 VG, } \\
\text { intramuscularly with booster }\end{array}$ & $\begin{array}{c}\text { C. jejuni } \\
\text { C97Anses640 (5.0) } \\
\text { and Day } 19\end{array}$ & 42 & $5.99 \pm 1.48$ & $8.02 \pm 1.19$ & $\begin{array}{l}\text { Significant } 2.03 \log 10 \\
\text { reductions upon } \\
\text { heterologous } \\
\text { challenge }\end{array}$ & Meunier et al. [50] \\
\hline 17 & $\begin{array}{l}\text { DNA vaccine (prime) with } \\
300 \mu \mathrm{g} \text { of purified DNA of } \\
\text { FlgL cloned into pcDNA3 } \\
\text { plasmids mixed with } 50 \mu \mathrm{g} \\
\text { of CpG ODN2007 and } \\
\text { subunit vaccine (boost) with } \\
100 \mu \mathrm{g} \text { of recombinant FlgL } \\
\text { emulsified with } \\
\text { MONTANIDETM ISA70 VG, } \\
\text { intramuscularly with booster }\end{array}$ & $\begin{array}{l}\text { C. jejuni } \\
\text { C97Anses640 (5.0) } \\
\text { and Day } 19\end{array}$ & 42 & $\begin{array}{l}4.39 \pm 2.37 \\
(\mathrm{GenEq} / \mathrm{g})\end{array}$ & $\begin{array}{l}5.45 \pm 2.61 \\
(\mathrm{GenEq} / \mathrm{g})\end{array}$ & $\begin{array}{l}\text { Non-significant } 1.06 \\
\log 10 \text { GenEq/g } \\
\text { reductions upon } \\
\text { heterologous } \\
\text { challenge }\end{array}$ & Meunier et al. [50] \\
\hline 18 & $\begin{array}{l}\text { DNA vaccine (prime) with } \\
300 \mu \mathrm{g} \text { of purified DNA of } \\
\text { hypothetical protein } \\
\text { (YP99838.1) cloned into } \\
\text { pcDNA3 plasmids mixed } \\
\text { with } 50 \mu \mathrm{g} \text { of CpG ODN2007 } \\
\text { and subunit vaccine (boost) } \\
\text { with } 100 \mu \mathrm{g} \text { of recombinant } \\
\text { YP99838.1 emulsified with } \\
\text { MONTANIDETM ISA70 VG, } \\
\text { intramuscularly with booster }\end{array}$ & $\begin{array}{l}\text { C. jejuni } \\
\text { C97Anses640 (5.0) } \\
\text { and Day } 19\end{array}$ & 42 & $5.94 \pm 1.48$ & $8.02 \pm 1.19$ & $\begin{array}{l}\text { Significant } 2.08 \log 10 \\
\text { reductions upon } \\
\text { heterologous } \\
\text { challenge }\end{array}$ & Meunier et al. [50] \\
\hline
\end{tabular}


Table 3. Cont.

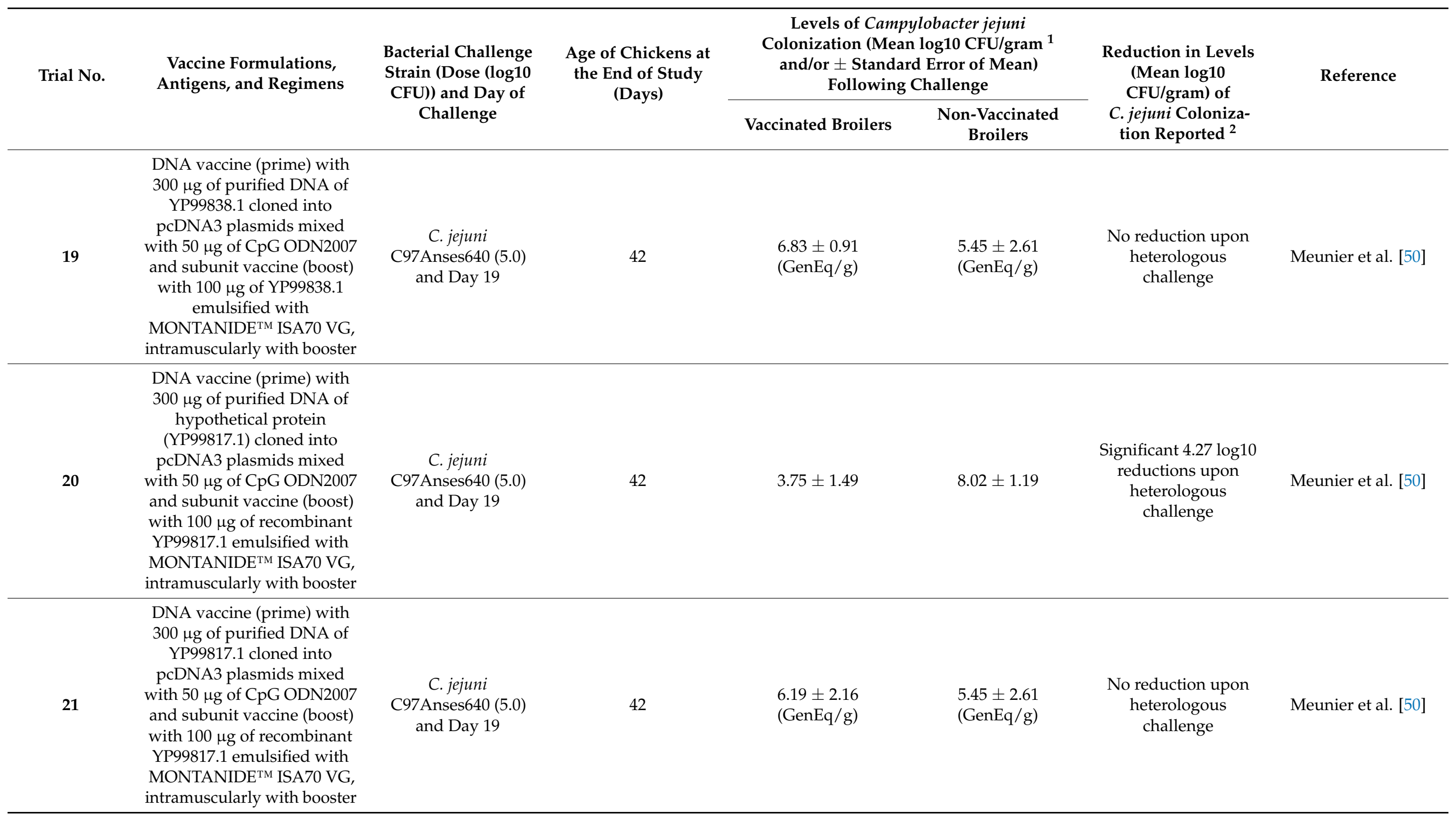


Table 3. Cont

\begin{tabular}{|c|c|c|c|c|c|c|c|}
\hline Trial No. & $\begin{array}{l}\text { Vaccine Formulations, } \\
\text { Antigens, and Regimens }\end{array}$ & $\begin{array}{l}\text { Bacterial Challenge } \\
\text { Strain (Dose (log10 } \\
\text { CFU)) and Day of } \\
\text { Challenge }\end{array}$ & $\begin{array}{l}\text { Age of Chickens at } \\
\text { the End of Study } \\
\text { (Days) }\end{array}$ & \multicolumn{2}{|c|}{$\begin{array}{l}\text { Levels of Campylobacter jejuni } \\
\text { Colonization (Mean log10 CFU/gram } 1 \\
\text { and/or } \pm \text { Standard Error of Mean) } \\
\text { Following Challenge }\end{array}$} & $\begin{array}{l}\text { Reduction in Levels } \\
\text { (Mean log10 } \\
\text { CFU/gram) of } \\
\text { C. jejuni Coloniza- } \\
\text { tion Reported }^{2} \\
\end{array}$ & Reference \\
\hline 22 & $\begin{array}{l}\text { DNA vaccine with } 300 \mu \mathrm{g} \text { of } \\
\text { purified DNA of YP99817.1 } \\
\text { cloned into pcDNA3 } \\
\text { plasmids mixed with } 50 \mu \mathrm{g} \\
\text { of CpG ODN2007, } \\
\text { intramuscularly with booster }\end{array}$ & $\begin{array}{l}\text { C. jejuni } \\
\text { C97Anses640 (5.0) } \\
\text { and Day } 19\end{array}$ & 42 & 7.04 & $6.2^{3}$ & $\begin{array}{l}\text { No reduction upon } \\
\text { heterologous } \\
\text { challenge }\end{array}$ & Meunier et al. [50] \\
\hline 23 & $\begin{array}{l}\text { Subunit vaccine with } 100 \mu \mathrm{g} \\
\text { of recombinant YP99817.1 } \\
\text { emulsified with } \\
\text { MONTANIDETM ISA70 VG, } \\
\text { intramuscularly with booster }\end{array}$ & $\begin{array}{l}\text { C. jejuni } \\
\text { C97Anses640 (5.0) } \\
\text { and Day } 19\end{array}$ & 42 & 7.87 & 7.03 & $\begin{array}{l}\text { No reduction upon } \\
\text { heterologous } \\
\text { challenge }\end{array}$ & Meunier et al. [50] \\
\hline 24 & $\begin{array}{l}\text { DNA vaccine (prime) with } \\
300 \mu g \text { of purified DNA of } \\
\text { flagellar hook-basal body } \\
\text { complex protein (FlgE-1) } \\
\text { cloned into pcDNA3 } \\
\text { plasmids mixed with } 50 \mu \mathrm{g} \\
\text { of CpG ODN2007 and } \\
\text { subunit vaccine (boost) with } \\
100 \mu \mathrm{g} \text { of recombinant FlgE-1 } \\
\text { emulsified with } \\
\text { MONTANIDETM ISA70 VG, } \\
\text { intramuscularly with booster }\end{array}$ & $\begin{array}{l}\text { C. jejuni } \\
\text { C97Anses640 (5.0) } \\
\text { and Day } 19\end{array}$ & 42 & $5.8^{3}$ & $8.02 \pm 1.19$ & $\begin{array}{l}\text { Non-significant } 2.20 \\
\text { log10 reductions } \\
\text { (a wide range of } \\
\text { individual colonized } \\
\text { broilers was } \\
\text { observed in the work } \\
\text { of Meunier et al.) } \\
\text { upon heterologous } \\
\text { challenge }\end{array}$ & Meunier et al. [50] \\
\hline
\end{tabular}


Table 3. Cont

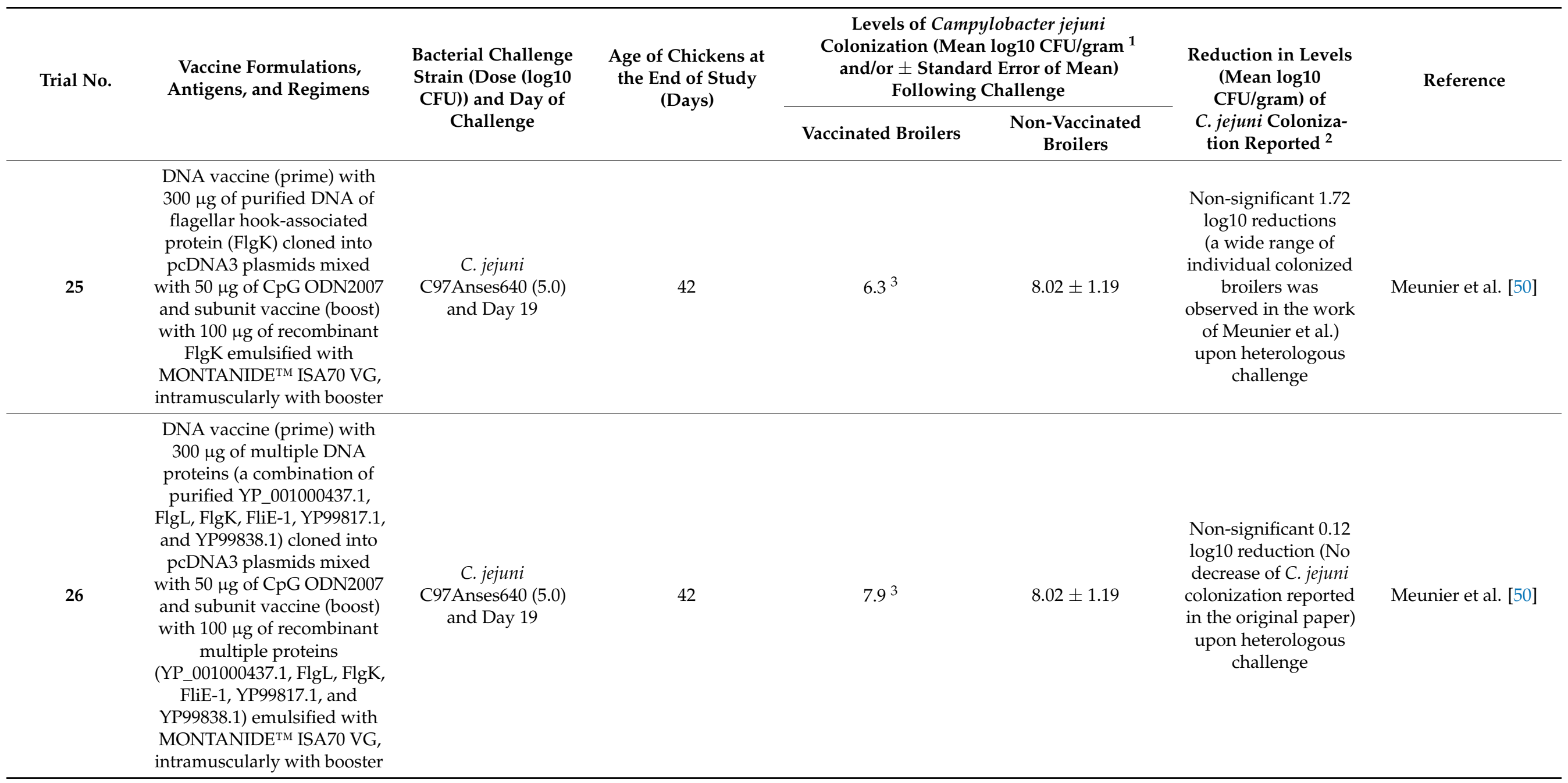


Table 3. Cont.

\begin{tabular}{|c|c|c|c|c|c|c|c|}
\hline Trial No. & $\begin{array}{l}\text { Vaccine Formulations, } \\
\text { Antigens, and Regimens }\end{array}$ & $\begin{array}{l}\text { Bacterial Challenge } \\
\text { Strain (Dose (log10 } \\
\text { CFU)) and Day of } \\
\text { Challenge }\end{array}$ & $\begin{array}{l}\text { Age of Chickens at } \\
\text { the End of Study } \\
\text { (Days) }\end{array}$ & \multicolumn{2}{|c|}{$\begin{array}{c}\text { Levels of Campylobacter jejuni } \\
\text { Colonization (Mean log10 CFU/gram } 1 \\
\text { and/or } \pm \text { Standard Error of Mean) } \\
\text { Following Challenge }\end{array}$} & $\begin{array}{l}\text { Reduction in Levels } \\
\text { (Mean log10 } \\
\text { CFU/gram) of } \\
\text { C. jejuni Coloniza- } \\
\text { tion Reported }^{2}\end{array}$ & Reference \\
\hline 27 & $\begin{array}{l}\text { DNA vaccine with } 100 \mu \mathrm{g} \text { of } \\
\text { purified DNA of flagellin A } \\
\text { protein (FlaA) cloned into } \\
\text { pcDNA3 plasmid mixed } \\
\text { with } 25 \mu \mathrm{g} \text { of CpG ODN2007, } \\
\text { subcutaneously with booster }\end{array}$ & $\begin{array}{l}\text { C. jejuni 81-176 (5.0) } \\
\text { and Day } 21\end{array}$ & 42 & $\begin{array}{c}7.7^{3} \\
\text { (geometric mean) }\end{array}$ & $\begin{array}{l}7.8^{3} \text { (geometric } \\
\text { mean) }\end{array}$ & $\begin{array}{l}\text { Non-significant } \\
0.1 \text { geometric mean } \\
\log 10 \text { reduction }\end{array}$ & Meunier et al. [51] \\
\hline 28 & $\begin{array}{l}\text { DNA vaccine with } 100 \mu \mathrm{g} \text { of } \\
\text { purified DNA of FlaA cloned } \\
\text { into pcDNA3 plasmid mixed } \\
\text { with } 25 \mu \mathrm{g} \text { of CpG ODN2007, } \\
\text { intramuscularly with booster }\end{array}$ & $\begin{array}{l}\text { C. jejuni 81-176 (5.0) } \\
\text { and Day } 21\end{array}$ & 42 & $\begin{array}{c}5.0^{3} \\
\text { (geometric mean) }\end{array}$ & $\begin{array}{l}5.2^{3} \text { (geometric } \\
\text { mean) }\end{array}$ & $\begin{array}{l}\text { Non-significant } \\
0.2 \text { median } \log 10 \\
\text { reductions }\end{array}$ & Meunier et al. [51] \\
\hline 29 & $\begin{array}{l}\text { DNA vaccine (prime) with } \\
150 \mu \mathrm{g} \text { of purified DNA of } \\
\text { FlaA into pcDNA3 plasmid } \\
\text { mixed with } 25 \mu \mathrm{g} \text { of CpG } \\
\text { ODN2007 and subunit } \\
\text { vaccine (boost) with } 100 \mu \mathrm{g} \\
\text { of recombinant FlaA } \\
\text { emulsified with } \\
\text { MONTANIDE } \\
\text { intramuscularly with booster }\end{array}$ & $\begin{array}{l}\text { C. jejuni 81-176 (5.0) } \\
\text { and Day } 21\end{array}$ & 42 & $\begin{array}{c}5.3^{3} \\
\text { (geometric mean) }\end{array}$ & $\begin{array}{l}5.2^{3} \text { (geometric } \\
\text { mean) }\end{array}$ & No reduction & Meunier et al. [51] \\
\hline 30 & $\begin{array}{l}\text { Subunit vaccine with } 240 \mu \mathrm{g} \\
\text { of recombinant } \\
\text { Campylobacter adhesion } \\
\text { protein to fibronectin } \\
\text { (CadF) }^{6} \text { mixed with } \\
\text { MONTANIDE }{ }^{\mathrm{TM}} \text { ISA } 70 \mathrm{VG} \text {, } \\
\text { intramuscularly with booster }\end{array}$ & $\begin{array}{l}\text { C. jejuni F38011 (8.3) } \\
\text { and Day } 20\end{array}$ & 27 & 6.04 (median) & 7.76 (median) & $\begin{array}{l}1.71 \text { median } \log 10 \\
\text { reductions } 5\end{array}$ & $\begin{array}{l}\text { Neal-McKinney et al. } \\
\text { [25] }\end{array}$ \\
\hline
\end{tabular}


Table 3. Cont.

\begin{tabular}{|c|c|c|c|c|c|c|c|}
\hline Trial No. & $\begin{array}{l}\text { Vaccine Formulations, } \\
\text { Antigens, and Regimens }\end{array}$ & $\begin{array}{l}\text { Bacterial Challenge } \\
\text { Strain (Dose (log10 } \\
\text { CFU)) and Day of } \\
\text { Challenge }\end{array}$ & $\begin{array}{l}\text { Age of Chickens at } \\
\text { the End of Study } \\
\text { (Days) }\end{array}$ & \multicolumn{2}{|c|}{$\begin{array}{c}\text { Levels of Campylobacter jejuni } \\
\text { Colonization (Mean log10 CFU/gram } 1 \\
\text { and/or } \pm \text { Standard Error of Mean) } \\
\text { Following Challenge }\end{array}$} & $\begin{array}{l}\text { Reduction in Levels } \\
\text { (Mean log10 } \\
\text { CFU/gram) of } \\
\text { C. jejuni Coloniza- } \\
\text { tion Reported }^{2}\end{array}$ & Reference \\
\hline 31 & $\begin{array}{l}\text { Subunit vaccine with } 240 \mu \mathrm{g} \\
\text { recombinant FlaA } 6 \text { mixed } \\
\text { with MONTANIDE }{ }^{\mathrm{TM}} \text { ISA } 70 \\
\text { VG, intramuscularly with } \\
\text { booster }\end{array}$ & $\begin{array}{l}\text { C. jejuni F38011 (8.3) } \\
\text { and Day } 20\end{array}$ & 27 & 4.41 (median) & 7.76 (median) & $\begin{array}{l}3.35 \text { median } \log 10 \\
\text { reductions } 5\end{array}$ & $\begin{array}{l}\text { Neal-McKinney et al. } \\
{[25]}\end{array}$ \\
\hline 32 & $\begin{array}{c}\text { Subunit vaccine with } 240 \mu \mathrm{g} \\
\text { recombinant fibronectin-like } \\
\text { protein A (FlpA) }{ }^{6} \text { mixed } \\
\text { with MONTANIDE } \\
\text { VG, intramuscularly with } \\
\text { booster }\end{array}$ & $\begin{array}{l}\text { C. jejuni F38011 (8.3) } \\
\text { and Day } 20\end{array}$ & 27 & 4.65 (median) & 7.76 (median) & $\begin{array}{l}3.11 \text { median } \log 10 \\
\text { reductions } 5\end{array}$ & $\begin{array}{l}\text { Neal-McKinney et al. } \\
{[25]}\end{array}$ \\
\hline 33 & $\begin{array}{l}\text { Subunit vaccine with } 240 \mu \mathrm{g} \\
\text { recombinant a component of } \\
\text { multidrug efflux pump } \\
(\mathrm{CmeC})^{6} \text { mixed with } \\
\text { MONTANIDE } \\
\text { intramuscularly with booster }\end{array}$ & $\begin{array}{l}\text { C. jejuni F38011 (8.3) } \\
\text { and Day } 20\end{array}$ & 27 & 6.39 (median) & 7.76 (median) & $\begin{array}{l}\text { No effect of } \\
\text { reduction due to the } \\
\text { widest range in the } \\
\text { level of colonization } \\
\text { observed by the } \\
\text { authors from the } \\
\text { original paper (even } \\
1.37 \text { median log10 } \\
\text { reduction calculated } \\
\text { from the supplement } \\
\text { table provided }{ }^{5} \text { ) }\end{array}$ & $\begin{array}{l}\text { Neal-McKinney et al. } \\
{[25]}\end{array}$ \\
\hline 34 & $\begin{array}{l}\text { Subunit vaccine of } 240 \mu \mathrm{g} \mathrm{a} \\
\text { fusion protein of } \\
\text { recombinant } \\
\text { CadF-FlaA-FlpA }^{7} \text { mixed } \\
\text { with MONTANIDETM ISA } 70 \\
\text { VG, intramuscularly } \\
\text { with booster }\end{array}$ & $\begin{array}{l}\text { C. jejuni F38011 (8.3) } \\
\text { and Day } 20\end{array}$ & 27 & 4.6 (median) & 7.76 (median) & $\begin{array}{l}3.16 \text { median } \log 10 \\
\text { reductions } 5\end{array}$ & $\begin{array}{l}\text { Neal-McKinney et al. } \\
{[25]}\end{array}$ \\
\hline
\end{tabular}


Table 3. Cont.

\begin{tabular}{|c|c|c|c|c|c|c|c|}
\hline Trial No. & $\begin{array}{l}\text { Vaccine Formulations, } \\
\text { Antigens, and Regimens }\end{array}$ & $\begin{array}{l}\text { Bacterial Challenge } \\
\text { Strain (Dose (log10 } \\
\text { CFU)) and Day of } \\
\text { Challenge }\end{array}$ & $\begin{array}{l}\text { Age of Chickens at } \\
\text { the End of Study } \\
\text { (Days) }\end{array}$ & \multicolumn{2}{|c|}{$\begin{array}{c}\text { Levels of Campylobacter jejuni } \\
\text { Colonization (Mean log10 CFU/gram } 1 \\
\text { and/or } \pm \text { Standard Error of Mean) } \\
\text { Following Challenge }\end{array}$} & $\begin{array}{l}\text { Reduction in Levels } \\
\text { (Mean log10 } \\
\text { CFU/gram) of } \\
\text { C. jejuni Coloniza- } \\
\text { tion Reported }{ }^{2}\end{array}$ & Reference \\
\hline 35 & $\begin{array}{l}10^{8} \text { cells of } E \text {. coli wzy::kan } \\
\text { strain vectored vaccine } \\
\text { expressing } C \text {. jejuni protein } \\
\text { glycosylation (N-glycan), } \\
\text { orally with booster }\end{array}$ & $\begin{array}{l}\text { C. jejuni } 81-176(6.0) \\
\text { and Day } 28\end{array}$ & 35 & $\begin{array}{l}5.7^{3} \text { (median) in } \\
\text { Trial\#1 } \\
7.6^{3} \text { (median) in } \\
\text { Trial\#2 }\end{array}$ & $\begin{array}{l}9.0^{3} \text { (median) in } \\
\text { Trial\#1 } \\
9.6^{3} \text { (median) in } \\
\text { Trial\#2 }\end{array}$ & $\begin{array}{c}\text { Significant } 3.30 \\
\text { median log10 } \\
\text { reductions in Trial\#1 } \\
\text { upon heterologous } \\
\text { challenge } \\
\text { Significant } 2.00 \\
\text { median log10 } \\
\text { reductions in Trial\#2 } \\
\text { upon heterologous } \\
\text { challenge }\end{array}$ & Nothaft et al. [46] \\
\hline 36 & $\begin{array}{l}\text { A formalin-killed whole-cell } \\
\text { vaccine with } 6.75 \times 10^{7} \mathrm{CFU} \\
\text { of bacterins mixed with oil } \\
\text { adjuvants, subcutaneously }\end{array}$ & $\begin{array}{l}\text { C. jejuni PD-316 (5.0) } \\
\text { and Day } 72\end{array}$ & 128 & $6.8^{3}$ & $7.5^{3}$ & $\begin{array}{l}\text { Non-significant } 0.7 \\
\log 10 \text { reduction }\end{array}$ & Okamura et al. [52] \\
\hline 37 & $\begin{array}{l}\text { A formalin-killed whole-cell } \\
\text { vaccine with } 6.75 \times 10^{7} \mathrm{CFU} \\
\text { of bacterins mixed with } \\
\text { aluminum hydroxide gel } \\
\text { adjuvant, subcutaneously } \\
\text { with booster }\end{array}$ & $\begin{array}{l}\text { C. jejuni PD-316 (5.0) } \\
\text { and Day } 72\end{array}$ & 128 & $6.7^{3}$ & $7.5^{3}$ & $\begin{array}{l}\text { Non-significant } 0.8 \\
\log 10 \text { reduction }{ }^{5}\end{array}$ & Okamura et al. [52] \\
\hline 38 & $\begin{array}{l}\text { Subunit vaccine with } 40 \mu \mathrm{g} \\
\text { of recombinant NHC } \\
\text { flagellin mixed with } 0.4 \mathrm{M} \\
\text { urea, } 10 \mathrm{mM} \text { Tris pH } 9.0,20 \% \\
\text { glycerol, } 5 \text { mM sucrose, in } \\
\text { ovo }\end{array}$ & $\begin{array}{l}\text { C. jejuni 81-116 (5.0) } \\
\text { and Day } 18\end{array}$ & 25 & $6.8^{3}$ & $7.3^{3}$ & $\begin{array}{l}\text { Non-significant } 0.5 \\
\log 10 \text { reduction }\end{array}$ & Radomska et al. [53] \\
\hline
\end{tabular}


Table 3. Cont.

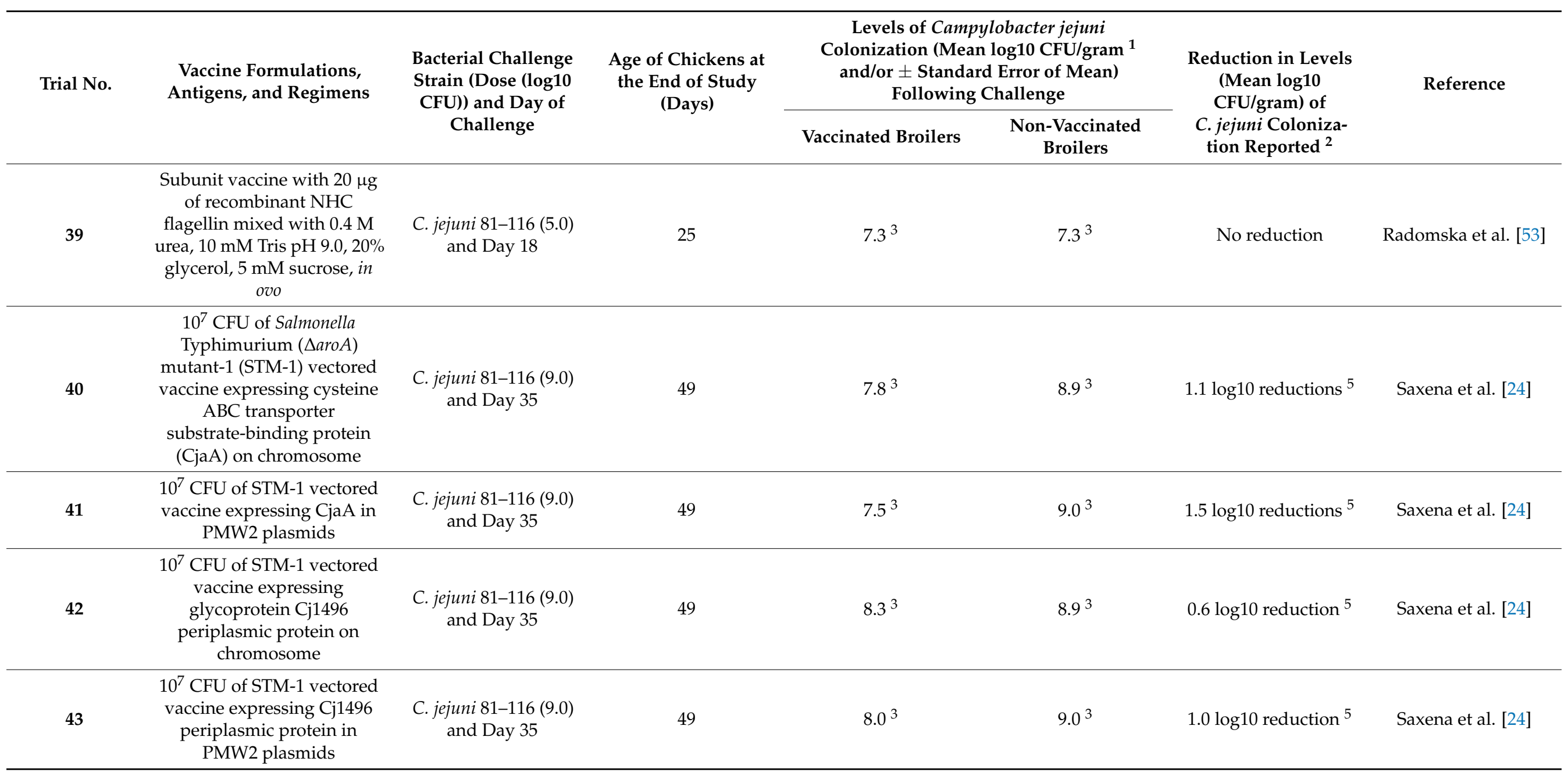


Table 3. Cont.

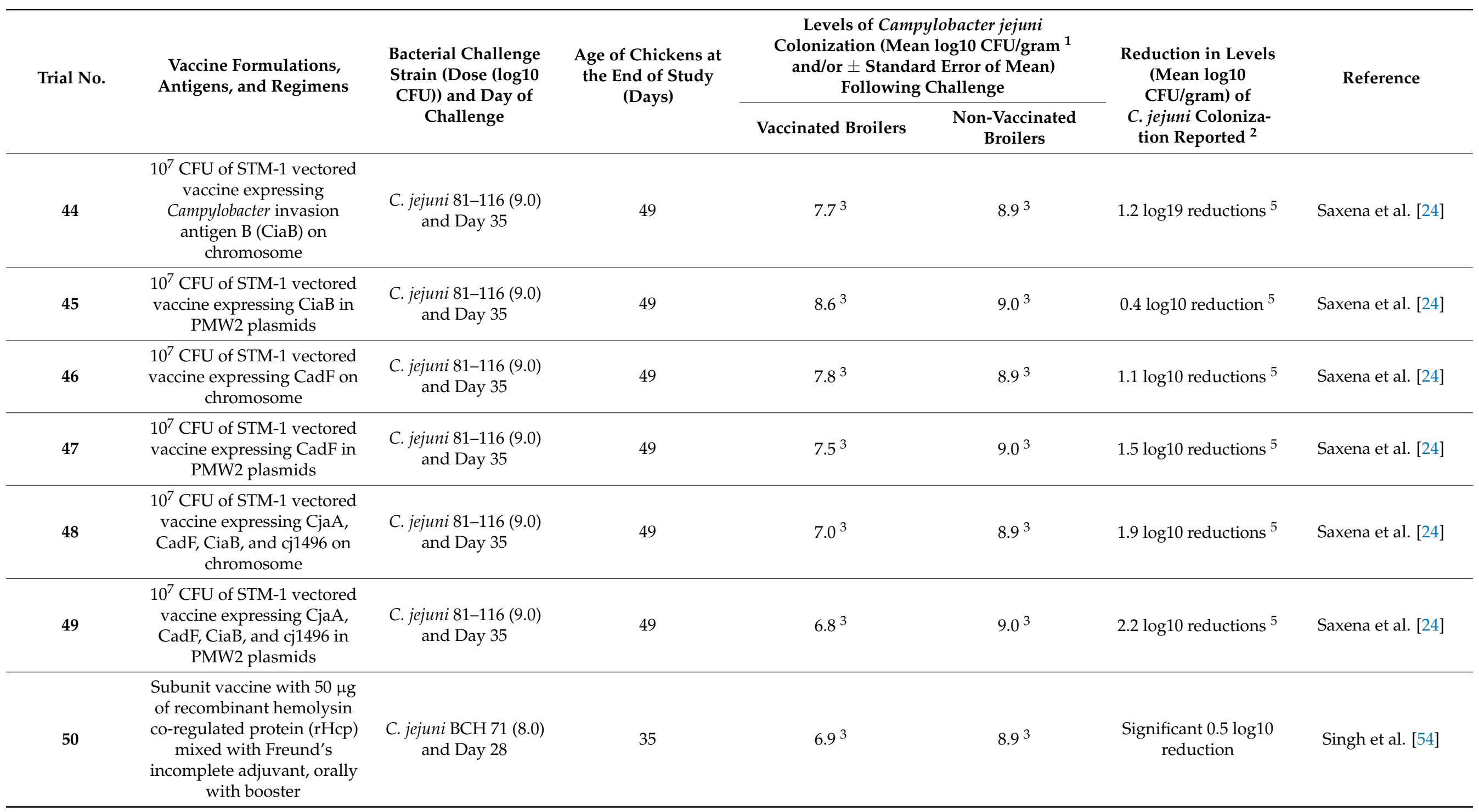


Table 3. Cont.

\begin{tabular}{|c|c|c|c|c|c|c|c|}
\hline Trial No. & $\begin{array}{l}\text { Vaccine Formulations, } \\
\text { Antigens, and Regimens }\end{array}$ & $\begin{array}{l}\text { Bacterial Challenge } \\
\text { Strain (Dose (log10 } \\
\text { CFU)) and Day of } \\
\text { Challenge }\end{array}$ & $\begin{array}{l}\text { Age of Chickens at } \\
\text { the End of Study } \\
\text { (Days) }\end{array}$ & \multicolumn{2}{|c|}{$\begin{array}{c}\text { Levels of Campylobacter jejuni } \\
\text { Colonization (Mean log10 CFU/gram } 1 \\
\text { and/or } \pm \text { Standard Error of Mean) } \\
\text { Following Challenge }\end{array}$} & $\begin{array}{c}\text { Reduction in Levels } \\
\text { (Mean log10 } \\
\text { CFU/gram) of } \\
\text { C. jejuni Coloniza- } \\
\text { tion Reported }^{2}\end{array}$ & Reference \\
\hline 51 & $\begin{array}{l}\text { Subunit vaccine with } 50 \mu \mathrm{g} \\
\text { of rHcp entrapped in } \\
\text { chitosan-Sodium } \\
\text { tripolyphosphate } \\
\text { nanoparticles (CS-TPP NPs) } \\
\text { (CS-TPP-rhcp), orally } \\
\text { with booster }\end{array}$ & $\begin{array}{l}\text { C. jejuni BCH } 71(8.0) \\
\text { and Day } 28\end{array}$ & 35 & $6.5^{3}$ & 7.53 & $\begin{array}{l}\text { Significant } 1.0 \log 10 \\
\text { reduction (as } \\
\text { reported in the } \\
\text { original paper) }\end{array}$ & Singh et al. [54] \\
\hline 52 & $\begin{array}{l}\text { Cell lysate vaccine with } 4.3 \\
\mu g \text { of } C \text {. jejuni cell } \\
\text { lysates, orally }\end{array}$ & $\begin{array}{l}\text { C. jejuni 81-176 (7.0) } \\
\text { and Day } 15\end{array}$ & 37 & $\begin{array}{l}5.7^{3} \text { in Trial\#1 } \\
6.3^{3} \text { in Trial\#2 }\end{array}$ & $\begin{array}{l}7.8^{3} \text { in Trial\#1 } \\
7.9^{3} \text { in Trial\#2 }\end{array}$ & $\begin{array}{l}\text { Significant } 2.14 \log 10 \\
\text { reductions in Trial\#1 } \\
\text { (reported in the } \\
\text { original paper) } \\
\text { Significant } 1.92 \text { log10 } \\
\text { reductions in Trial\#2 } \\
\text { (reported in the } \\
\text { original paper) }\end{array}$ & $\begin{array}{l}\text { Taha-Abdelaziz et al. } \\
\text { [55] }\end{array}$ \\
\hline 53 & $\begin{array}{c}\text { Cell lysate vaccine with } 21 \\
\mu \mathrm{g} \text { of } C \text {. jejuni cell } \\
\text { lysates, orally }\end{array}$ & $\begin{array}{l}\text { C. jejuni 81-176 (7.0) } \\
\text { and Day } 15\end{array}$ & 37 & $6.9^{3}$ & $7.6^{3}$ & $\begin{array}{l}\text { Non-significant } 0.7 \\
\quad \log \text { reduction }\end{array}$ & $\begin{array}{l}\text { Taha-Abdelaziz et al. } \\
\text { [55] }\end{array}$ \\
\hline 54 & $\begin{array}{l}\text { Cell lysate vaccine with } 4.3 \\
\mu \mathrm{g} \text { of } C \text {. jejuni cell lysates } \\
\text { combined with } 5 \mu \mathrm{g} \text { of } \\
\text { E-CpG, orally }\end{array}$ & $\begin{array}{l}\text { C. jejuni 81-176 (7.0) } \\
\text { and Day } 15\end{array}$ & 37 & $5.5^{3}$ & $\begin{array}{l}7.9^{3} \\
6.9^{3}\end{array}$ & $\begin{array}{l}\text { Significant } 2.42 \log 10 \\
\text { reductions } \\
\text { (compared with PBS } \\
\text { as reported in the } \\
\text { original paper) } \\
\text { Significant } 1.42 \log 10 \\
\text { reductions } \\
\text { (compared with } \\
\text { E-CpG alone) in this } \\
\text { review as it was } \\
\text { presented in the } \\
\text { figure of the } \\
\text { original paper }\end{array}$ & $\begin{array}{l}\text { Taha-Abdelaziz et al. } \\
\text { [55] }\end{array}$ \\
\hline
\end{tabular}


Table 3. Cont.

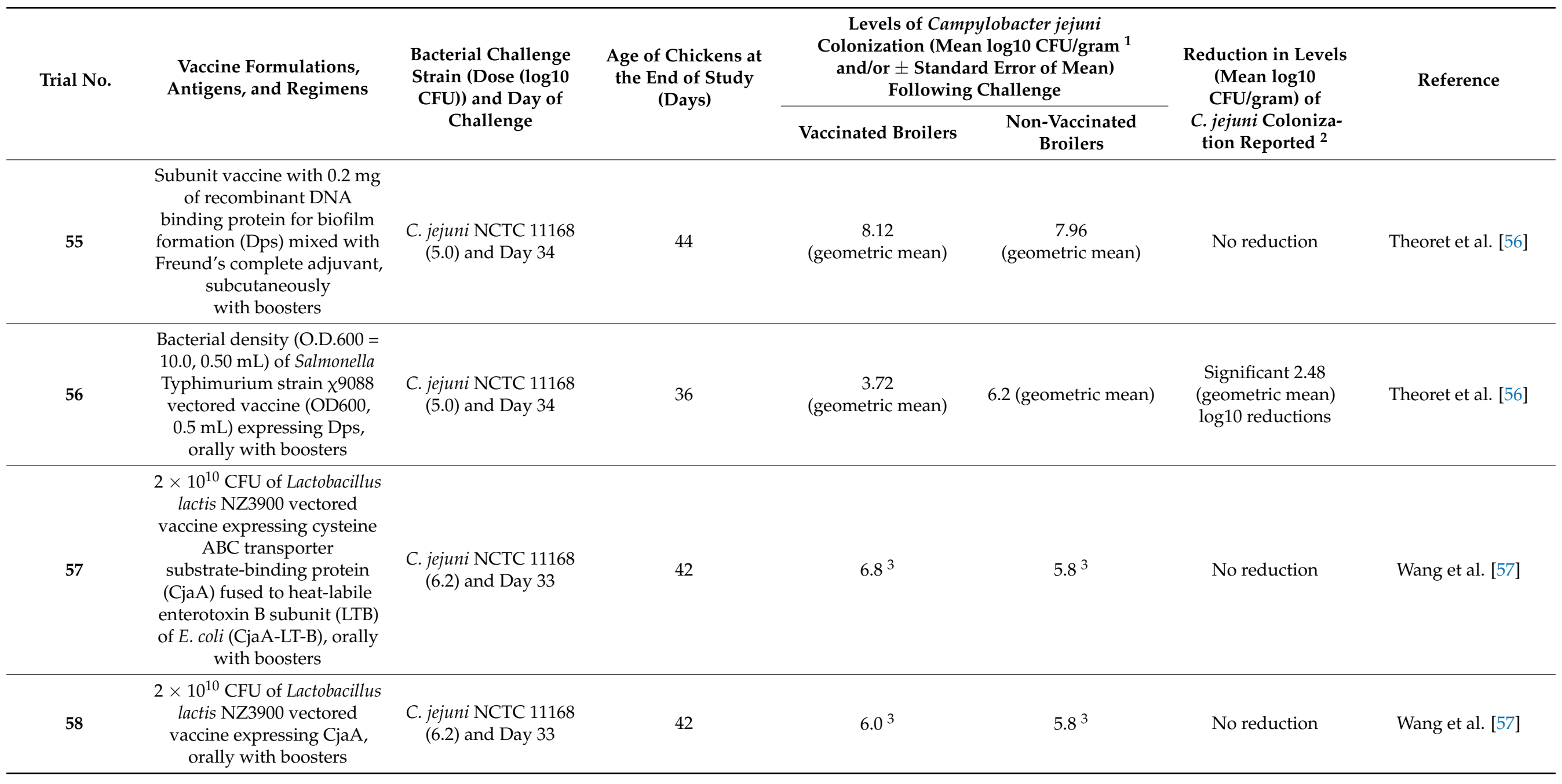


Table 3. Cont.

\begin{tabular}{|c|c|c|c|c|c|c|c|}
\hline \multirow[t]{2}{*}{ Trial No. } & \multirow[t]{2}{*}{$\begin{array}{l}\text { Vaccine Formulations, } \\
\text { Antigens, and Regimens }\end{array}$} & \multirow{2}{*}{$\begin{array}{l}\text { Bacterial Challenge } \\
\text { Strain (Dose (log10 } \\
\text { CFU)) and Day of } \\
\text { Challenge }\end{array}$} & \multirow[t]{2}{*}{$\begin{array}{l}\text { Age of Chickens at } \\
\text { the End of Study } \\
\text { (Days) }\end{array}$} & \multicolumn{2}{|c|}{$\begin{array}{c}\text { Levels of Campylobacter jejuni } \\
\text { Colonization (Mean log10 CFU/gram } 1 \\
\text { and/or } \pm \text { Standard Error of Mean) } \\
\text { Following Challenge }\end{array}$} & \multirow{2}{*}{$\begin{array}{l}\text { Reduction in Levels } \\
\text { (Mean log10 } \\
\text { CFU/gram) of } \\
\text { C. jejuni Coloniza- } \\
\text { tion Reported }^{2}\end{array}$} & \multirow[t]{2}{*}{ Reference } \\
\hline & & & & Vaccinated Broilers & $\begin{array}{l}\text { Non-Vaccinated } \\
\text { Broilers }\end{array}$ & & \\
\hline 59 & $\begin{array}{c}\text { Avirulent Salmonella } \\
\text { Typhimurium } \text { ×3987 strain } \\
\text { vectored vaccine (108 cells) } \\
\text { expressing CjaA, orally } \\
\text { with boosters }\end{array}$ & $\begin{array}{l}\text { C. jejuni labeled with } \\
\text { pUOA18 (8.3) and } \\
\text { Day } 28\end{array}$ & 40 & $\begin{array}{c}<3.00 \text { (below } \\
\text { detection limit) }\end{array}$ & $9.1^{3}$ & $\begin{array}{l}\text { Significant } 6.0 \log 10 \\
\text { reductions (reported } \\
\text { in the original paper) } \\
\text { upon heterologous } \\
\text { challenge }\end{array}$ & Wyszynska et al. [26] \\
\hline 60 & $\begin{array}{c}10^{8} \text { CFU of Salmonella } \\
\text { Enteritidis (SE) vectored } \\
\text { vaccine expressing Omp18 } \\
\text { protein (Cj0013), } \\
\text { peptidoglycan associated } \\
\text { lipoprotein of Salmonella } \\
\text { (PAL of Salmonella), and high } \\
\text { mobility group box 1 protein } \\
\text { (HMGB1), orally }\end{array}$ & $\begin{array}{l}\text { C. jejuni field strain } \\
\text { (6.8) and Day } 7\end{array}$ & 43 & $7.14 \pm 0.29$ & $7.70 \pm 0.29$ & $\begin{array}{l}\text { Non-significant } 0.56 \\
\log 10 \text { reduction }\end{array}$ & Yang et al. [58] \\
\hline 61 & $\begin{array}{l}10^{8} \text { CFU of SE vectored } \\
\text { vaccine expressing HMGB1, } \\
\text { PAL of Salmonella, and } \\
\text { Cj0013, orally }\end{array}$ & $\begin{array}{l}\text { C. jejuni field strain } \\
\text { (6.8) and Day } 7\end{array}$ & 43 & $7.5^{3}$ & $7.70 \pm 0.29$ & $\begin{array}{l}\text { Non-significant } 0.2 \\
\text { log10 reduction } \\
\text { (non-significant) }\end{array}$ & Yang et al. [58] \\
\hline 62 & $\begin{array}{c}10^{8} \text { CFU of SE vectored } \\
\text { vaccine expressing Cj0013, } \\
\text { HMGB1, and PAL of } \\
\text { Salmonella, orally }\end{array}$ & $\begin{array}{l}\text { C. jejuni field strain } \\
\text { (6.8) and Day } 7\end{array}$ & 43 & $7.6^{3}$ & $7.70 \pm 0.29$ & $\begin{array}{c}\text { Non-significant } 0.1 \\
\log 10 \text { reduction }\end{array}$ & Yang et al. [58] \\
\hline \multicolumn{8}{|c|}{ 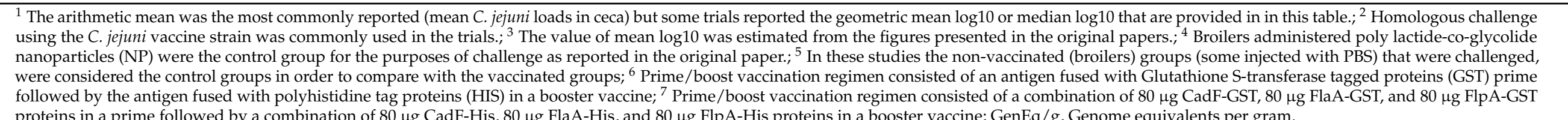 } \\
\hline
\end{tabular}




\subsection{Vaccine Types}

Overall, eight vaccine types (bacterial vector-based, subunit, DNA, a combination of vaccine, killed-whole cells, cell lysate, crude cell lysate, and conjugated vaccines) were identified in this review using the two definitions of vaccine efficacy. Based on the 62 trials with the C. jejuni loads in ceca of the vaccinated and non-vaccinated broilers investigated, the bacterial vector-based vaccines were the most frequently used in 19 trials from seven papers. Of these, Salmonella Typhimurium (ST) and Salmonella Enteritis (SE) vectors were used in 16 trials, followed by Lactobacillus lactis (L. lactis) $(n=2)$ and Escherichia coli (E. coli) $(n=1)$. Subunit vaccine $(n=12)$ and DNA (prime) with subunit (boost) vaccine $(n=12)$ were identified in six and two papers. Crude lysate vaccine was used in eight trials from one paper. DNA, Whole-cell lysate, and conjugated vaccines were used in nine trials from four papers. The remaining vaccine type used in two trials from one paper was a killed-whole cell vaccine.

Based on the 45 trials with the prevalence of colonized broilers reported, subunit vaccine was the most frequently used in 13 trials from seven papers, followed by a combination of DNA (prime) and subunit (boost) vaccines from 12 trials of two papers. The crude cell lysate vaccine was found in eight trials of one paper [47]. The bacterial vector-based vaccines used in six trials from three papers were E. coli wzy::kan strain [46], ST 99088 strain [56], and Avirulent ST $\chi 3987$ strain [26]. While the use of whole-cell lysate $(n=3)$ and DNA $(n=3)$ vaccines were found in three papers.

\subsection{Vaccine Antigens and Vaccine Regimens}

The C. jejuni antigens evaluated in the vaccine efficacy studies included in this review are summarized in Table 4.

A total of 23 C. jejuni antigens used as single and/or multiple antigens in vaccine trials were identified using both terms of vaccine efficacy in this review. Based on the 62 trials with evaluations of $C$. jejuni loads reported, variations of antigens used in the trials, vaccine regimens, and the broiler age at the end of study (ranging from 25 to 128 days) were identified (Table 3). Of these, total outer membrane proteins (OMP) used in the crude lysate vaccine were the most frequent antigen evaluated after homologous challenge in 8 trials from one paper. This antigen was used either encapsulated with biodegradable and biocompatible poly (lactide-co-glycolide) nanoparticles (OMP-NP) or non-encapsulated via oral or subcutaneous vaccinations with a booster. Following this, cysteine $\mathrm{ABC}$ transporter substrate-binding protein $(\mathrm{CjaA})$ used in five trials from three papers were evaluated in the oral vaccination with booster(s) using three different bacterial vectored vaccines: ST $(\triangle \operatorname{aro} A)$ mutant-1 (STM-1) $(n=3)$, L. lactis NZ3900 strain $(n=2)$ and, avirulent ST $\chi 398$ strain $(n=1)$. Of these five trials, the only vaccine trial using the avirulent ST $\chi 398$ strain expressing CjaA was challenged with heterologous C. jejuni strains. Flagellin A protein used in 4 trials (two papers) were evaluated three different vaccine types (DNA, subunit, and DNA (prime)/subunit (boost) vaccines) and routes of administrations (intramuscularly or subcutaneously with booster). Hypothetical protein YP99817.1 protein used in four trials was evaluated using three different vaccine types booster as well, but only one vaccinated route (intramuscularly with/without booster) was used and these trials were from only one paper. Three antigens (i.e., Campylobacter adhesion protein to fibronectin (CadF), whole-cell lysate, and capsular polysaccharide (CPS)) were used and evaluated upon homologous challenge in nine trials from four different papers. CadF identified in two papers was evaluated in subunit (intramuscularly with booster) and STM-1 vectored vaccines (orally with booster) after homologous challenge. Whole lysate and CPS were used in six trials from two papers. The whole-cell lysate was orally administrated with/without E-CpG, whereas CPS was conjugated with diphtheria toxoid of Corynebacterium diphtheriae vaccine (CPSconj) and mixed with $10 \mu \mathrm{g}$ of CPG ODN 2007 for subcutaneous vaccination with a booster. The remaining trials using other antigens were less frequent studies (less than 2 trials) (Table 3$)$. 
Table 4. Summary of Campylobacter jejuni vaccine antigens identified in this review.

\begin{tabular}{|c|c|c|}
\hline Vaccine Antigen & $\begin{array}{c}\text { Role of Antigen in Promoting C. jejuni } \\
\text { Colonization of Host }\end{array}$ & Reference \\
\hline Bacterin & $\begin{array}{l}\text { Killed-whole bacterial cells (multiple } \\
\text { antigens) used for immunization }\end{array}$ & Okamura et al. [52] \\
\hline C. jejuni glycoprotein Cj1496 & Invasion & Kakuda and DiRita [59] \\
\hline $\begin{array}{l}\text { Campylobacter adhesion protein to } \\
\text { fibronectin (CadF) }\end{array}$ & Adhesion & Konkel et al. [60] \\
\hline $\begin{array}{l}\text { Campylobacter invasion antigen B } \\
\text { (CiaB) }\end{array}$ & Invasion & Konkel [61] \\
\hline $\begin{array}{l}\text { Campylobacter surface-exposed } \\
\text { lipoprotein A (JlpA) }\end{array}$ & Adhesion & Jin et al. [62] \\
\hline Capsular polysaccharide (CPS) & Serum resistance & Keo et al. [63] \\
\hline $\begin{array}{l}\text { Component of multidrug efflux pump } \\
\text { (CmeC) }\end{array}$ & Multidrug efflux system & Lin et al. [64] \\
\hline $\begin{array}{l}\text { Cysteine ABC transporter } \\
\text { substrate-binding protein }(\mathrm{CjaA})\end{array}$ & $\begin{array}{l}\text { Campylobacter solute-binding protein and } \\
\text { a component of the ABC transport system }\end{array}$ & Muller et al. [65] \\
\hline $\begin{array}{l}\text { DNA binding protein for biofilm } \\
\text { formation (Dps) }\end{array}$ & Biofilm formation & Theoret et al. [56] \\
\hline Fibronectin-like protein A (FlpA) & Adhesion & Konkel et al. [66] \\
\hline $\begin{array}{l}\text { Flagellar hook-associated protein } \\
\text { (FlgK) }\end{array}$ & Motility & $\begin{array}{l}\text { Fernando et al., [67] and Neal-McKinney } \\
\text { and Konkel [68] }\end{array}$ \\
\hline $\begin{array}{l}\text { Flagellar hook-basal body complex } \\
\text { protein (FlgE-1) }\end{array}$ & $\begin{array}{c}\text { Motility and deliver Campylobacter } \\
\text { invasion antigens (Cia proteins) to host } \\
\text { cells }\end{array}$ & Neal-McKinney and Konkel [68] \\
\hline Flagellin & Motility & Nachamkin et al. [69] \\
\hline Flagellin A protein (FlaA) & Motility, adherence, and invasion & Wassenaar et al. [70] \\
\hline Flagellin protein family (FlgL) & $\begin{array}{l}\text { Deliver Campylobacter invasion antigens } \\
\text { (Cia proteins) to host cells }\end{array}$ & Neal-McKinney and Konkel [68] \\
\hline Hemolysin co-regulated protein (Hcp) & $\begin{array}{l}\text { Secretion tube and effector protein in } \\
\text { Campylobacter jejuni Type VI secretion } \\
\text { system (T6SS) for adhesion and invasion }\end{array}$ & $\begin{array}{l}\text { Liaw et al. [71] and } \\
\text { Lertpiriyapong et al. [72] }\end{array}$ \\
\hline Hypothetical protein (YP_999817.1) & Not fully described & Meunier et al. [50] \\
\hline Hypothetical protein (YP_999838.1) & Protein-protein interactions & Meunier et al. [50] \\
\hline $\begin{array}{l}\text { N-linked protein glycosylation } \\
\text { (N-glycan) }\end{array}$ & $\begin{array}{l}\text { Protect } C \text {. jejuni surface proteins from gut } \\
\text { protease and attachment to host cells }\end{array}$ & $\begin{array}{l}\text { Alemka et al. [73] and } \\
\text { Karlyshev et al. [74] }\end{array}$ \\
\hline Outer membrane proteins & Adhesion and invasion & Chart et al. [75] \\
\hline $\begin{array}{l}\text { Peptidoglycan-associated essential } \\
\text { protein (PAL; Omp18; CjaD) }\end{array}$ & Maintenance cell wall & Godlewska et al. [76] \\
\hline Whole-cell lysate & Adhesion and invasion & Konkel and Joens [77] \\
\hline YP_001000437.1 & Activation/secretion of hemolysin & Meunier et al. [50] \\
\hline
\end{tabular}

Based on the prevalence of colonized broilers reported, several antigens were also identified in the 45 eligible trials conducted in various ages of broiler at the end of study ranging between 25 and 44 days old (Table 5). The antigens used in the 45 trials were a subset of the antigens used, based on the investigation of $C$. jejuni loads criteria except for an extra trial which was a subunit vaccine using recombinant flagellin A protein (FlaA) fused to heat-labile enterotoxin (LT-B) of E.coli (FlaA-LT-B) mixed with sodium carbonate, delivered orally with a booster (designated as Trial no. 63) in this review (Table 5). Of the 45 trials, the OMP (with/without NP) used in the crude lysate vaccine were the most 
common antigens used in eight trials, following this, FlaA ( $n=5$, three papers), hypothetical protein YP_999817.1 ( $n=4$, one paper), whole-cell lysate $(n=3$, one paper), and CjaA $(n=3$, two papers). Seven antigens were used in 14 trials from five papers using different vaccine formulations and regimens (Table 5). These seven antigens were DNA binding protein for biofilm formation (Dps), flagellin, hemolysin co-regulated protein (Hcp), flagellin protein family (FlgL), Campylobacter hemolysin activation/secretion protein (YP_001000437.1), C. jejuni surface-exposed lipoprotein A (JlpA), and hypothetical protein YP99838.1. While the remaining eight trials were utilized eight different antigens (six individual and two multiple antigens).

\subsection{Levels of C. jejuni Loads (log10 CFU/g) in Cecal Contents as Vaccine Efficacy}

The four different outcomes of vaccine efficacy reported from the 62 trials were identified in this review: no reduction $(n=9), \log 10$ reductions $(n=15)$, non-significant $\log 10$ reductions $(n=20)$, and significant $\log 10$ reductions $(n=18)$. The four different reporting outcomes of $\log 10 \mathrm{CFU} /$ gram were also identified in this review (i.e., genome equivalents per reaction per gram, median $\log 10$ reductions, geometric log10 reduction, and arithmetic mean $\log 10$ reduction).

The 18 trials reported significant $\log 10$ reductions ranging between $0.5 \log 10$ and $6.0 \log 10$ of C. jejuni cecal loads upon homologous/heterologous challenge. Of these, an avirulent ST $\chi 3987$ strain vectored vaccine expressing CjaA $\left(10^{8} \mathrm{CFU}\right)$ administrated orally and a booster was the most significant levels of reductions $(\sim 6.0 \log 10)$ after heterologous challenge reported [26]. Following this, the crude cell lysate vaccine contained $125 \mu \mathrm{g}$ of OMP or OMP-NP subcutaneously with booster (two trials) provided approximately $5.7 \log 10$ reductions after homologous challenges, compared to the broiler vaccinated with NP alone estimated from the figure provided in the original paper [47]. Eight trials reported significant reduction levels of $C$. jejuni loads varied between $2.0 \log 10$ and 4.27 (mean or median) $\log 10 \mathrm{CFU} / \mathrm{g}$ after homologous/heterologous challenge. Of the eight trials, four trials were a combination of DNA (prime) with subunit (boost) vaccines using four antigens: Campylobacter hemolysin activation/secretion protein, FlaA, fibronectin-like protein A (FlpA), flagellin protein family (FlgL), hypothetical protein YP99838.1, or hypothetical protein YP99817.1, and a CadF-FlaA-FlpA) were from one paper [50]. Another four trials (from three papers). Another four trials were cell lysate vaccines using $4.3 \mu \mathrm{g}$ of $\mathrm{C}$. jejuni cell lysates with/without $5 \mu \mathrm{g}$ of E-CpG (orally), E. coli wzy::kan strain vectored vaccine expressing C. jejuni protein glycosylation (N-glycan) (orally with a booster, Salmonella Typhimurium strain $\chi 9088$ vectored vaccine expressing DNA binding protein for biofilm formation (Dps) orally with a booster. The significant log10 reductions reported in seven trials were less than $1.0 \log 10 \mathrm{CFU} / \mathrm{g}$.

Moreover, 15 trials from two papers reported levels of $\log 10 \mathrm{CFU} / \mathrm{g}$ reductions without significant or non-significant reported. Of these, five trials with subunit vaccines contained recombinant CadF, FlaA, FlpA, a component of multidrug efflux pump (CmeC), a fusion protein of CadF-FlaA,-FlpA emulsified with MONTANIDE ${ }^{\text {TM }}$ ISA70 VG intramuscularly with booster provide various reduction levels (between 1.37 and 3.16 median $\log 10$ reductions) and the original paper reported the subunit with $\mathrm{CmeC}$ did not prevent C. jeuni colonization after homologous challenge due to a wide range of $C$. jejuni loads in the individual vaccinated broilers [25]. Ten trials (from one paper) used STM-1 vectored vaccine expressing various antigens from the inserted plasmids or ST chromosome orally with booster reported the reduction levels between $0.4 \log 10 \mathrm{CFU} / \mathrm{g}$ and $2.2 \log 10 \mathrm{CFU} / \mathrm{g}$ after homologous challenge, estimated from the figures provided in the original paper [24]. 
Table 5. Summary of the vaccine efficacy from the eligible trials based on the prevalence of colonized broilers at the end of study.

\begin{tabular}{|c|c|c|c|c|c|c|c|c|c|}
\hline \multirow{2}{*}{ Trial No } & \multirow{2}{*}{$\begin{array}{l}\text { Vaccine Formulations, } \\
\text { Antigens, and } \\
\text { Regimens }\end{array}$} & \multirow{2}{*}{$\begin{array}{l}\text { Age of } \\
\text { Chickens at the } \\
\text { End of Study } \\
\text { (Days) }\end{array}$} & \multicolumn{2}{|c|}{$\begin{array}{c}\text { Reductions of } C \text {. jejuni }(\log 10) \\
\text { Colonization in Cecal Contents after } \\
\text { Challenge }^{1}\end{array}$} & \multirow{2}{*}{$\begin{array}{l}\text { \% Colonized } \\
\text { Broilers in the } \\
\text { Vaccinated } \\
\text { Group } \\
\text { (Proportion) }\end{array}$} & \multirow{2}{*}{$\begin{array}{l}\% \text { Colonized } \\
\text { Broilers in the } \\
\text { Control Group } \\
\text { (Proportion) }\end{array}$} & \multirow{2}{*}{$\begin{array}{l}\text { Relative Risk }{ }^{6} \\
\quad(95 \% \text { CI) }\end{array}$} & \multirow{2}{*}{$\begin{array}{l}\text { Efficacy (\%) } \\
\quad \text { against } \\
\text { Colonization }\end{array}$} & \multirow{2}{*}{ Reference } \\
\hline & & & $\begin{array}{l}\text { Significant } \\
\text { (Yes/No) }\end{array}$ & $\begin{array}{l}\text { Reduction Levels } \\
\text { (Mean log10 } \\
\text { CFU/gram }{ }^{2} \text { ) } \\
\text { Reported }\end{array}$ & & & & & \\
\hline 1 & $\begin{array}{c}\text { Crude cell lysate } \\
\text { vaccine with } 125 \mu \mathrm{g} \text { of } \\
\text { total outer membrane } \\
\text { proteins (OMP) } \\
\text { encapsulated with ploy } \\
\text { lactide-co-glycolide } \\
\text { nanoparticles } \\
\text { (OMP-NP), orally } \\
\text { with booster }\end{array}$ & 42 & No & $\begin{array}{l}0.4 \log 10 \\
\text { reduction }\end{array}$ & $87.5(7 / 8)$ & $57.1(4 / 7)$ & $\begin{array}{l}1.53(0.76 \\
\text { and } 3.06)\end{array}$ & No effect & [47] \\
\hline 2 & $\begin{array}{l}125 \mu \mathrm{g} \text { of crude cell } \\
\text { lysate vaccine with } \\
\text { OMP, orally } \\
\text { with booster }\end{array}$ & 42 & No & $\begin{array}{l}0.8 \log 10 \\
\text { reduction } 3,4\end{array}$ & $62.5(5 / 8)$ & $57.1(4 / 7)^{4}$ & $\begin{array}{l}1.09(0.47 \\
\text { and } 2.52)\end{array}$ & No effect & [47] \\
\hline 3 & $\begin{array}{l}125 \mu \mathrm{g} \text { of crude cell } \\
\text { lysate vaccine with } \\
\text { OMPs-NP, } \\
\text { subcutaneously } \\
\text { with booster }\end{array}$ & 42 & Yes & $\begin{array}{l}5.7 \log 10 \\
\text { reductions }\end{array}$ & $0.0(0 / 8)$ & $57.1(4 / 7)$ & $\begin{array}{l}0.10(0.01 \\
\text { and } 1.56)\end{array}$ & 90 & [47] \\
\hline 4 & $\begin{array}{l}125 \mu \mathrm{g} \text { of crude cell } \\
\text { lysate vaccine with } \\
\text { OMP, orally } \\
\text { with booster }\end{array}$ & 42 & Yes & $\begin{array}{l}5.7 \log 10 \\
\text { reductions }\end{array}$ & $0.0(0 / 8)$ & $57.1(4 / 7)^{4}$ & $\begin{array}{l}0.10(0.01 \\
\text { and } 1.56)\end{array}$ & 90 & [47] \\
\hline
\end{tabular}


Table 5. Cont.

\begin{tabular}{|c|c|c|c|c|c|c|c|c|c|}
\hline \multirow{2}{*}{ Trial No } & \multirow{2}{*}{$\begin{array}{l}\text { Vaccine Formulations, } \\
\text { Antigens, and } \\
\text { Regimens }\end{array}$} & \multirow{2}{*}{$\begin{array}{l}\text { Age of } \\
\text { Chickens at the } \\
\text { End of Study } \\
\text { (Days) }\end{array}$} & \multicolumn{2}{|c|}{$\begin{array}{c}\text { Reductions of } C . j e j u n i(\log 10) \\
\text { Colonization in Cecal Contents after } \\
\text { Challenge }{ }^{1}\end{array}$} & \multirow{2}{*}{$\begin{array}{l}\% \text { Colonized } \\
\text { Broilers in the } \\
\text { Vaccinated } \\
\text { Group } \\
\text { (Proportion) }\end{array}$} & \multirow{2}{*}{$\begin{array}{l}\text { \% Colonized } \\
\text { Broilers in the } \\
\text { Control Group } \\
\text { (Proportion) }\end{array}$} & \multirow{2}{*}{$\begin{array}{l}\text { Relative Risk } \\
\quad(95 \% \text { CI })\end{array}$} & \multirow{2}{*}{$\begin{array}{c}\text { Efficacy }(\%)^{7} \\
\text { against } \\
\text { Colonization }\end{array}$} & \multirow{2}{*}{ Reference } \\
\hline & & & $\begin{array}{c}\text { Significant } \\
\text { (Yes/No) }\end{array}$ & $\begin{array}{l}\text { Reduction Levels } \\
\text { (Mean log10 } \\
\text { CFU/gram }{ }^{2} \text { ) } \\
\text { Reported }\end{array}$ & & & & & \\
\hline 5 & $\begin{array}{l}25 \mu \mathrm{g} \text { of crude cell } \\
\text { lysate vaccine with } \\
\text { OMP-NP, } \\
\text { subcutaneously } \\
\text { with booster }\end{array}$ & 42 & No & $\begin{array}{l}1.2 \log 10 \\
\text { reductions }\end{array}$ & $62.5(5 / 8)$ & $57.1(4 / 7)$ & $\begin{array}{l}1.09(0.47 \\
\text { and } 2.52)\end{array}$ & No effect & [47] \\
\hline 6 & $\begin{array}{l}250 \mu \mathrm{g} \text { of crude cell } \\
\text { lysate vaccine with } \\
\text { OMP-NP, orally } \\
\text { with booster }\end{array}$ & 42 & No & $\begin{array}{l}0.9 \log 10 \\
\text { reductions }\end{array}$ & $37.5(3 / 8)$ & $57.1(4 / 7)$ & $\begin{array}{l}0.66(0.22 \\
\text { and } 1.97)\end{array}$ & 34 & [47] \\
\hline 7 & $\begin{array}{l}25 \mu \mathrm{g} \text { of crude cell } \\
\text { lysate vaccine with } \\
\text { OMP, orally } \\
\text { with booster }\end{array}$ & 42 & No & $\begin{array}{l}1.6 \log 10 \\
\text { reductions }\end{array}$ & $66.7(\mathrm{NI})$ & $57.1(4 / 7)^{4}$ & $\begin{array}{l}\text { Unable to } \\
\text { calculate }\end{array}$ & $\begin{array}{l}\text { Unable to } \\
\text { calculate }\end{array}$ & [47] \\
\hline 8 & $\begin{array}{l}250 \mu \mathrm{g} \text { of crude cell } \\
\text { lysate vaccine with } \\
\text { OMP, orally } \\
\text { with booster }\end{array}$ & 42 & No & $\begin{array}{l}1.0 \log 10 \\
\text { reduction } 3,4\end{array}$ & $50.0(4 / 8)$ & $57.1(4 / 7)^{4}$ & $\begin{array}{l}0.88(0.34 \\
\text { and } 2.25)\end{array}$ & 13 & [47] \\
\hline 9 & $\begin{array}{c}10^{9} \text { CFU of L. lactis } \\
\text { NZ9000 strain vectored } \\
\text { vaccine expressing C. } \\
\text { jejuni surface-exposed } \\
\text { lipoprotein A (JlpA), } \\
\text { intragastrically } \\
\text { with booster }\end{array}$ & 35 & $\begin{array}{l}\text { Yes } \\
\text { Yes } \\
\text { Yes }\end{array}$ & $\begin{array}{l}0.79 \log 10 \\
\text { reduction in } \\
\text { Trial\#1 } \\
0.47 \log 10 \\
\text { reduction in } \\
\text { Trial\#2 } \\
0.482 \log 10 \\
\text { reduction in } \\
\text { Trial\#3 }\end{array}$ & $100.0(15 / 15)$ & $100.0(15 / 15)$ & $\begin{array}{l}1.00(1.00 \\
\text { and } 1.00)\end{array}$ & No effect & [48] \\
\hline
\end{tabular}


Table 5. Cont.

\begin{tabular}{|c|c|c|c|c|c|c|c|c|c|}
\hline \multirow{2}{*}{ Trial No } & \multirow{2}{*}{$\begin{array}{l}\text { Vaccine Formulations, } \\
\text { Antigens, and } \\
\text { Regimens }\end{array}$} & \multirow{2}{*}{$\begin{array}{l}\text { Age of } \\
\text { Chickens at the } \\
\text { End of Study } \\
\text { (Days) }\end{array}$} & \multicolumn{2}{|c|}{$\begin{array}{c}\text { Reductions of } C \cdot \text { jejuni }(\log 10) \\
\text { Colonization in Cecal Contents after } \\
\text { Challenge }{ }^{1}\end{array}$} & \multirow{2}{*}{$\begin{array}{l}\% \text { Colonized } \\
\text { Broilers in the } \\
\text { Vaccinated } \\
\text { Group } \\
\text { (Proportion) }\end{array}$} & \multirow{2}{*}{$\begin{array}{l}\text { \% Colonized } \\
\text { Broilers in the } \\
\text { Control Group } \\
\text { (Proportion) }\end{array}$} & \multirow{2}{*}{$\begin{array}{l}\text { Relative Risk } \\
\quad(95 \% \text { CI })\end{array}$} & \multirow{2}{*}{$\begin{array}{c}\text { Efficacy }(\%)^{7} \\
\text { against } \\
\text { Colonization }\end{array}$} & \multirow{2}{*}{ Reference } \\
\hline & & & $\begin{array}{c}\text { Significant } \\
\text { (Yes/No) }\end{array}$ & $\begin{array}{l}\text { Reduction Levels } \\
\text { (Mean log10 } \\
\text { CFU/gram }{ }^{2} \text { ) } \\
\text { Reported }\end{array}$ & & & & & \\
\hline 10 & $\begin{array}{l}\text { Subunit vaccine with } \\
50 \mu g \text { of recombinant } \\
\text { JlpA emulsified in } \\
\text { Freund's incomplete } \\
\text { adjuvant, } \\
\text { subcutaneously } \\
\text { with booster }\end{array}$ & 35 & NoYesYes & $\begin{array}{c}0.11 \log 10 \text { in } \\
\text { Trial\#1 } \\
0.69 \log 10 \text { in } \\
\text { Trial\#2 } \\
0.49 \log 10 \text { in } \\
\text { Trial\#3 }\end{array}$ & $100.0(15 / 15)$ & $100.0(15 / 15)$ & $\begin{array}{l}1.00(1.00 \\
\text { and } 1.00)\end{array}$ & No effect & [48] \\
\hline 14 & $\begin{array}{c}\text { DNA vaccine (prime) } \\
\text { with } 300 \mu \text { g of purified } \\
\text { DNA of Campylobacter } \\
\text { hemolysin } \\
\text { activation/secretion } \\
\text { protein } \\
\text { (YP_001000437.1) } \\
\text { cloned into pcDNA3 } \\
\text { plasmids mixed with } \\
50 \mu \text { g of CpG ODN2007 } \\
\text { and subunit vaccine } \\
\text { (boost) with } 100 \mu g \text { of } \\
\text { recombinant } \\
\text { YP_001000437.1 protein } \\
\text { emulsified with } \\
\text { MONTANIDETM ISA70 } \\
\text { VG, intramuscularly } \\
\text { with booster }\end{array}$ & 42 & Yes & $\begin{array}{l}3.61 \log 10 \\
\text { reduction upon } \\
\text { heterologous } \\
\text { challenge }\end{array}$ & $87.5(14 / 16)$ & $100.0(15 / 15)$ & $\begin{array}{l}0.88(0.73 \\
\text { and } 1.05)\end{array}$ & 13 & [50] \\
\hline
\end{tabular}


Table 5. Cont.

\begin{tabular}{|c|c|c|c|c|c|c|c|c|c|}
\hline \multirow{2}{*}{ Trial No } & \multirow{2}{*}{$\begin{array}{l}\text { Vaccine } \\
\text { Formulations, } \\
\text { Antigens, and } \\
\text { Regimens }\end{array}$} & \multirow{2}{*}{$\begin{array}{l}\text { Age of } \\
\text { Chickens at the } \\
\text { End of Study } \\
\text { (Days) }\end{array}$} & \multicolumn{2}{|c|}{$\begin{array}{c}\text { Reductions of } C . j e j u n i(\log 10) \\
\text { Colonization in Cecal Contents after } \\
\text { Challenge }{ }^{1}\end{array}$} & \multirow{2}{*}{$\begin{array}{l}\% \text { Colonized } \\
\text { Broilers in the } \\
\text { Vaccinated } \\
\text { Group } \\
\text { (Proportion) }\end{array}$} & \multirow{2}{*}{$\begin{array}{l}\text { \% Colonized } \\
\text { Broilers in the } \\
\text { Control Group } \\
\text { (Proportion) }\end{array}$} & \multirow{2}{*}{$\begin{array}{l}\text { Relative Risk }{ }^{6} \\
\quad(95 \% \text { CI) }\end{array}$} & \multirow{2}{*}{$\begin{array}{c}\text { Efficacy }(\%)^{7} \\
\text { against } \\
\text { Colonization }\end{array}$} & \multirow{2}{*}{ Reference } \\
\hline & & & $\begin{array}{l}\text { Significant } \\
\text { (Yes/No) }\end{array}$ & $\begin{array}{l}\text { Reduction Levels } \\
\text { (Mean } \log 10 \\
\text { CFU/gram }{ }^{2} \text { ) } \\
\text { Reported }\end{array}$ & & & & & \\
\hline 15 & $\begin{array}{c}\text { DNA vaccine } \\
\text { (prime) with } 300 \mu \mathrm{g} \\
\text { of purified DNA of } \\
\text { YP_001000437.1 } \\
\text { cloned into } \\
\text { pcDNA3 plasmids } \\
\text { mixed with } 50 \mu \mathrm{g} \text { of } \\
\text { CpG ODN2007 and } \\
\text { subunit vaccine } \\
\text { (boost) with } 100 \mu \mathrm{g} \\
\text { of recombinant } \\
\text { YP_001000437.1 } \\
\text { protein emulsified } \\
\text { with } \\
\text { MONTANIDETM } \\
\text { ISA70 VG, } \\
\text { intramuscularly } \\
\text { with booster }\end{array}$ & 42 & No & $\begin{array}{l}1.92 \log 10 \\
\text { GenEq/g } \\
\text { reductions upon } \\
\text { heterologous } \\
\text { challenge }\end{array}$ & $80.0(12 / 15)$ & $93.8(15 / 16)$ & $\begin{array}{l}0.85(0.64 \\
\text { and } 1.13)\end{array}$ & 15 & {$[50]$} \\
\hline
\end{tabular}


Table 5. Cont.

\begin{tabular}{|c|c|c|c|c|c|c|c|c|c|}
\hline \multirow{2}{*}{ Trial No } & \multirow{2}{*}{$\begin{array}{l}\text { Vaccine Formulations, } \\
\text { Antigens, and } \\
\text { Regimens }\end{array}$} & \multirow{2}{*}{$\begin{array}{l}\text { Age of } \\
\text { Chickens at the } \\
\text { End of Study } \\
\text { (Days) }\end{array}$} & \multicolumn{2}{|c|}{$\begin{array}{c}\text { Reductions of } C . \text { jejuni }(\log 10) \\
\text { Colonization in Cecal Contents after } \\
\text { Challenge }{ }^{1}\end{array}$} & \multirow{2}{*}{$\begin{array}{l}\% \text { Colonized } \\
\text { Broilers in the } \\
\text { Vaccinated } \\
\text { Group } \\
\text { (Proportion) }\end{array}$} & \multirow{2}{*}{$\begin{array}{l}\% \text { Colonized } \\
\text { Broilers in the } \\
\text { Control Group } \\
\text { (Proportion) }\end{array}$} & \multirow{2}{*}{$\begin{array}{l}\text { Relative Risk } \\
\quad \text { (95\% CI) }\end{array}$} & \multirow{2}{*}{$\begin{array}{c}\text { Efficacy }(\%)^{7} \\
\text { against } \\
\text { Colonization }\end{array}$} & \multirow{2}{*}{ Reference } \\
\hline & & & $\begin{array}{c}\text { Significant } \\
\text { (Yes/No) }\end{array}$ & $\begin{array}{l}\text { Reduction Levels } \\
\text { (Mean log10 } \\
\text { CFU/gram }{ }^{2} \text { ) } \\
\text { Reported }\end{array}$ & & & & & \\
\hline 16 & $\begin{array}{l}\text { DNA vaccine (prime) } \\
\text { with } 300 \mu \text { g of purified } \\
\text { DNA of flagellin } \\
\text { protein family (FlgL) } \\
\text { cloned into pcDNA3 } \\
\text { plasmids mixed with } \\
50 \mu \mathrm{g} \text { of CpG ODN2007 } \\
\text { and subunit vaccine } \\
\text { (boost) with } 100 \mu \mathrm{g} \text { of } \\
\text { recombinant FlgL } \\
\text { emulsified with } \\
\text { MONTANIDE }{ }^{\mathrm{TM}} \text { ISA70 } \\
\text { VG, intramuscularly } \\
\text { with booster }\end{array}$ & 42 & Yes & $\begin{array}{l}2.03 \log 10 \\
\text { reductions upon } \\
\text { heterologous } \\
\text { challenge }\end{array}$ & $100.0(15 / 15)$ & $100.0(15 / 15)$ & $\begin{array}{l}1.00(1.00 \\
\text { and } 1.00)\end{array}$ & No effect & {$[50]$} \\
\hline 17 & $\begin{array}{l}\text { DNA vaccine (prime) } \\
\text { with } 300 \mu \mathrm{g} \text { of purified } \\
\text { DNA of FlgL cloned } \\
\text { into pcDNA3 plasmids } \\
\text { mixed with } 50 \mu \mathrm{g} \text { of } \\
\text { CpG ODN2007 and } \\
\text { subunit vaccine (boost) } \\
\text { with } 100 \mu \mathrm{g} \text { of } \\
\text { recombinant FlgL } \\
\text { emulsified with } \\
\text { MONTANIDE }{ }^{\mathrm{TM}} \text { ISA70 } \\
\text { VG, intramuscularly } \\
\text { with booster }\end{array}$ & 42 & No & $\begin{array}{c}1.06 \log 10 \\
\text { GenEq/g } \\
\text { reductions upon } \\
\text { heterologous } \\
\text { challenge }\end{array}$ & $75.0(12 / 16)$ & $93.8(15 / 16)$ & $\begin{array}{l}0.80(0.59 \\
\text { and } 1.09)\end{array}$ & 20 & {$[50]$} \\
\hline
\end{tabular}


Table 5. Cont.

\begin{tabular}{|c|c|c|c|c|c|c|c|c|c|}
\hline \multirow{2}{*}{ Trial No } & \multirow{2}{*}{$\begin{array}{l}\text { Vaccine Formulations, } \\
\text { Antigens, and } \\
\text { Regimens }\end{array}$} & \multirow{2}{*}{$\begin{array}{l}\text { Age of } \\
\text { Chickens at the } \\
\text { End of Study } \\
\text { (Days) }\end{array}$} & \multicolumn{2}{|c|}{$\begin{array}{l}\text { Reductions of } C \text {. jejuni }(\log 10) \\
\text { Colonization in Cecal Contents after } \\
\text { Challenge }{ }^{1}\end{array}$} & \multirow{2}{*}{$\begin{array}{l}\% \text { Colonized } \\
\text { Broilers in the } \\
\text { Vaccinated } \\
\text { Group } \\
\text { (Proportion) }\end{array}$} & \multirow{2}{*}{$\begin{array}{l}\text { \% Colonized } \\
\text { Broilers in the } \\
\text { Control Group } \\
\text { (Proportion) }\end{array}$} & \multirow{2}{*}{$\begin{array}{l}\text { Relative Risk } \\
\quad(95 \% \text { CI })\end{array}$} & \multirow{2}{*}{$\begin{array}{c}\text { Efficacy }(\%)^{7} \\
\text { against } \\
\text { Colonization }\end{array}$} & \multirow{2}{*}{ Reference } \\
\hline & & & $\begin{array}{c}\text { Significant } \\
\text { (Yes/No) }\end{array}$ & $\begin{array}{l}\text { Reduction Levels } \\
\text { (Mean log10 } \\
\text { CFU/gram }{ }^{2} \text { ) } \\
\text { Reported }\end{array}$ & & & & & \\
\hline 18 & $\begin{array}{c}\text { DNA vaccine (prime) } \\
\text { with } 300 \mu \text { g of purified } \\
\text { DNA of hypothetical } \\
\text { protein (YP99838.1) } \\
\text { cloned into pcDNA3 } \\
\text { plasmids mixed with } \\
50 \mu \mathrm{g} \text { of CpG ODN2007 } \\
\text { and subunit vaccine } \\
\text { (boost) with } 100 \mu \mathrm{g} \text { of } \\
\text { recombinant YP99838.1 } \\
\text { emulsified with } \\
\text { MONTANIDE } \\
\text { VG, intramuscularly } \\
\text { with booster }\end{array}$ & 42 & Yes & $\begin{array}{l}2.08 \log 10 \\
\text { reductions upon } \\
\text { heterologous } \\
\text { challenge }\end{array}$ & $100.0(14 / 14)$ & $100.0(15 / 15)$ & $\begin{array}{l}1.00(1.00 \\
\text { and } 1.00)\end{array}$ & No effect & {$[50]$} \\
\hline 19 & $\begin{array}{l}\text { DNA vaccine (prime) } \\
\text { with } 300 \mu \mathrm{g} \text { of purified } \\
\text { DNA of YP99838.1 } \\
\text { cloned into pcDNA3 } \\
\text { plasmids mixed with } \\
50 \mu \mathrm{g} \text { of CpG ODN2007 } \\
\text { and subunit vaccine } \\
\text { (boost) with } 100 \mu \mathrm{g} \text { of } \\
\text { YP99838.1 emulsified } \\
\text { with MONTANIDETM } \\
\text { ISA70 VG, } \\
\text { intramuscularly } \\
\text { with booster }\end{array}$ & 42 & No & $\begin{array}{l}\text { No reduction } \\
\text { upon } \\
\text { heterologous } \\
\text { challenge }\end{array}$ & $100.0(14 / 14)$ & $93.8(15 / 16)$ & $\begin{array}{l}1.07(0.94 \\
\text { and } 1.21)\end{array}$ & No effect & [50] \\
\hline
\end{tabular}


Table 5. Cont.

\begin{tabular}{|c|c|c|c|c|c|c|c|c|c|}
\hline \multirow{2}{*}{ Trial No } & \multirow{2}{*}{$\begin{array}{l}\text { Vaccine Formulations, } \\
\text { Antigens, and } \\
\text { Regimens }\end{array}$} & \multirow{2}{*}{$\begin{array}{l}\text { Age of } \\
\text { Chickens at the } \\
\text { End of Study } \\
\text { (Days) }\end{array}$} & \multicolumn{2}{|c|}{$\begin{array}{l}\text { Reductions of } C \text {. jejuni }(\log 10) \\
\text { Colonization in Cecal Contents after } \\
\text { Challenge }{ }^{1}\end{array}$} & \multirow{2}{*}{$\begin{array}{l}\% \text { Colonized } \\
\text { Broilers in the } \\
\text { Vaccinated } \\
\text { Group } \\
\text { (Proportion) }\end{array}$} & \multirow{2}{*}{$\begin{array}{l}\text { \% Colonized } \\
\text { Broilers in the } \\
\text { Control Group } \\
\text { (Proportion) }\end{array}$} & \multirow{2}{*}{$\begin{array}{c}\text { Relative Risk }{ }^{6} \\
\quad(95 \% \text { CI })\end{array}$} & \multirow{2}{*}{$\begin{array}{c}\text { Efficacy }(\%)^{7} \\
\text { against } \\
\text { Colonization }\end{array}$} & \multirow{2}{*}{ Reference } \\
\hline & & & $\begin{array}{c}\text { Significant } \\
\text { (Yes/No) }\end{array}$ & $\begin{array}{l}\text { Reduction Levels } \\
\text { (Mean log10 } \\
\text { CFU/gram }{ }^{2} \text { ) } \\
\text { Reported }\end{array}$ & & & & & \\
\hline 20 & $\begin{array}{c}\text { DNA vaccine (prime) } \\
\text { with } 300 \mu \text { g of purified } \\
\text { DNA of hypothetical } \\
\text { protein (YP99817.1) } \\
\text { cloned into pcDNA3 } \\
\text { plasmids mixed with } \\
50 \mu \mathrm{g} \text { of CpG ODN2007 } \\
\text { and subunit vaccine } \\
\text { (boost) with } 100 \mu \mathrm{g} \text { of } \\
\text { recombinant YP99817.1 } \\
\text { emulsified with } \\
\text { MONTANIDE } \\
\text { VG, intramuscularly } \\
\text { with booster }\end{array}$ & 42 & Yes & $\begin{array}{l}4.27 \log 10 \\
\text { reductions upon } \\
\text { heterologous } \\
\text { challenge }\end{array}$ & $92.3(12 / 13)$ & $100.0(15 / 15)$ & $\begin{array}{l}0.92(0.79 \\
\text { and } 1.08)\end{array}$ & 8 & {$[50]$} \\
\hline 21 & $\begin{array}{l}\text { DNA vaccine (prime) } \\
\text { with } 300 \mu \mathrm{g} \text { of purified } \\
\text { DNA of YP99817.1 } \\
\text { cloned into pcDNA3 } \\
\text { plasmids mixed with } \\
50 \mu \mathrm{g} \text { of CpG ODN2007 } \\
\text { and subunit vaccine } \\
\text { (boost) with } 100 \mu \mathrm{g} \text { of } \\
\text { recombinant YP99817.1 } \\
\text { emulsified with } \\
\text { MONTANIDE ISA70 } \\
\text { VG, intramuscularly } \\
\text { with booster }\end{array}$ & 42 & No & $\begin{array}{l}\text { No reduction } \\
\text { upon } \\
\text { heterologous } \\
\text { challenge }\end{array}$ & $93.8(15 / 16)$ & $93.8(15 / 16)$ & $\begin{array}{l}1.00(0.84 \\
\text { and } 1.20)\end{array}$ & No effect & [50] \\
\hline
\end{tabular}


Table 5. Cont.

\begin{tabular}{|c|c|c|c|c|c|c|c|c|c|}
\hline \multirow{2}{*}{ Trial No } & \multirow{2}{*}{$\begin{array}{l}\text { Vaccine Formulations, } \\
\text { Antigens, and Regimens }\end{array}$} & \multirow{2}{*}{$\begin{array}{l}\text { Age of } \\
\text { Chickens at the } \\
\text { End of Study } \\
\text { (Days) }\end{array}$} & \multicolumn{2}{|c|}{$\begin{array}{c}\text { Reductions of } C \cdot \text { jejuni }(\log 10) \\
\text { Colonization in Cecal Contents after } \\
\text { Challenge }{ }^{1}\end{array}$} & \multirow{2}{*}{$\begin{array}{l}\% \text { Colonized } \\
\text { Broilers in the } \\
\text { Vaccinated } \\
\text { Group } \\
\text { (Proportion) }\end{array}$} & \multirow{2}{*}{$\begin{array}{l}\% \text { Colonized } \\
\text { Broilers in the } \\
\text { Control Group } \\
\text { (Proportion) }\end{array}$} & \multirow{2}{*}{$\begin{array}{l}\text { Relative Risk }{ }^{6} \\
\quad(95 \% \text { CI) }\end{array}$} & \multirow{2}{*}{$\begin{array}{l}\text { Efficacy }(\%)^{7} \\
\text { against } \\
\text { Colonization }\end{array}$} & \multirow{2}{*}{ Reference } \\
\hline & & & $\begin{array}{l}\text { Significant } \\
\text { (Yes/No) }\end{array}$ & $\begin{array}{l}\text { Reduction Levels } \\
\text { (Mean log10 } \\
\text { CFU/gram }{ }^{2} \text { ) } \\
\text { Reported }\end{array}$ & & & & & \\
\hline 22 & $\begin{array}{l}\text { DNA vaccine with } 300 \mu \mathrm{g} \\
\text { of purified DNA of } \\
\text { YP99817.1 cloned into } \\
\text { pcDNA3 plasmids mixed } \\
\text { with } 50 \mu \mathrm{g} \text { of CpG } \\
\text { ODN2007, } \\
\text { intramuscularly } \\
\text { with booster }\end{array}$ & 42 & No & $\begin{array}{l}\text { No reduction } \\
\text { upon } \\
\text { heterologous } \\
\text { challenge }\end{array}$ & $100.0(15 / 15)$ & $100.0(15 / 15)$ & $\begin{array}{l}1.00(1.00 \\
\text { and } 1.00)\end{array}$ & No effect & [50] \\
\hline 23 & $\begin{array}{l}\text { Subunit vaccine with } 100 \\
\mu g \text { of recombinant } \\
\text { YP99817.1 emulsified } \\
\text { with MONTANIDETM } \\
\text { ISA70 VG, } \\
\text { intramuscularly } \\
\text { with booster }\end{array}$ & 42 & No & $\begin{array}{l}\text { No reduction } \\
\text { upon } \\
\text { heterologous } \\
\text { challenge }\end{array}$ & $100.0(15 / 15)$ & $100.0(15 / 15)$ & $\begin{array}{l}1.00(1.00 \\
\text { and } 1.00)\end{array}$ & No effect & {$[50]$} \\
\hline 24 & $\begin{array}{l}\text { DNA vaccine (prime) } \\
\text { with } 300 \mu \text { g of purified } \\
\text { DNA of flagellar } \\
\text { hook-basal body complex } \\
\text { protein (FlgE-1) cloned } \\
\text { into pcDNA3 plasmids } \\
\text { mixed with } 50 \mu \mathrm{g} \text { of CpG } \\
\text { ODN2007 and subunit } \\
\text { vaccine (boost) with } 100 \\
\mu \mathrm{g} \text { of recombinant FlgE-1 } \\
\text { emulsified with } \\
\text { MONTANIDETM ISA70 } \\
\text { VG, intramuscularly } \\
\text { with booster }\end{array}$ & 42 & No & $\begin{array}{c}2.20 \log 10 \\
\text { reductions a wide } \\
\text { range of } \\
\text { individual } \\
\text { colonized broilers } \\
\text { was presented in } \\
\text { Figure 2A of the } \\
\text { original paper } \\
\text { upon } \\
\text { heterologous } \\
\text { challenge }\end{array}$ & $91.7(11 / 12)$ & $100.0(15 / 15)$ & $\begin{array}{l}0.92(0.77 \\
\text { and } 1.09)\end{array}$ & 8 & {$[50]$} \\
\hline
\end{tabular}


Table 5. Cont.

\begin{tabular}{|c|c|c|c|c|c|c|c|c|c|}
\hline \multirow{2}{*}{ Trial No } & \multirow{2}{*}{$\begin{array}{l}\text { Vaccine Formulations, } \\
\text { Antigens, and } \\
\text { Regimens }\end{array}$} & \multirow{2}{*}{$\begin{array}{l}\text { Age of } \\
\text { Chickens at the } \\
\text { End of Study } \\
\text { (Days) }\end{array}$} & \multicolumn{2}{|c|}{$\begin{array}{c}\text { Reductions of } C \cdot \text { jejuni }(\log 10) \\
\text { Colonization in Cecal Contents after } \\
\text { Challenge }{ }^{1}\end{array}$} & \multirow{2}{*}{$\begin{array}{l}\% \text { Colonized } \\
\text { Broilers in the } \\
\text { Vaccinated } \\
\text { Group } \\
\text { (Proportion) }\end{array}$} & \multirow{2}{*}{$\begin{array}{l}\% \text { Colonized } \\
\text { Broilers in the } \\
\text { Control Group } \\
\text { (Proportion) }\end{array}$} & \multirow{2}{*}{$\begin{array}{c}\text { Relative Risk } \\
\text { (95\% CI) }\end{array}$} & \multirow{2}{*}{$\begin{array}{l}\text { Efficacy }(\%)^{7} \\
\text { against } \\
\text { Colonization }\end{array}$} & \multirow{2}{*}{ Reference } \\
\hline & & & $\begin{array}{l}\text { Significant } \\
\text { (Yes/No) }\end{array}$ & $\begin{array}{l}\text { Reduction Levels } \\
\text { (Mean log10 } \\
\text { CFU/gram }{ }^{2} \text { ) } \\
\text { Reported }\end{array}$ & & & & & \\
\hline 25 & $\begin{array}{l}\text { DNA vaccine (prime) } \\
\text { with } 300 \mu \text { g of purified } \\
\text { DNA of flagellar } \\
\text { hook-associated protein } \\
\text { (FlgK) cloned into } \\
\text { pcDNA3 plasmids } \\
\text { mixed with } 50 \mu \mathrm{g} \text { of } \\
\text { CpG ODN2007 and } \\
\text { subunit vaccine (boost) } \\
\text { with } 100 \mu \mathrm{g} \text { of } \\
\text { recombinant FlgK } \\
\text { emulsified with } \\
\text { MONTANIDETM ISA70 } \\
\text { VG, intramuscularly } \\
\text { with booster }\end{array}$ & 42 & No & $\begin{array}{c}1.72 \log 10 \\
\text { reductions but a } \\
\text { wide range of } \\
\text { individual } \\
\text { colonized broilers } \\
\text { was presented in } \\
\text { Figure 2A of the } \\
\text { original paper } \\
\text { upon } \\
\text { heterologous } \\
\text { challenge }\end{array}$ & $100.0(14 / 14)$ & $100.0(15 / 15)$ & $\begin{array}{l}1.00(1.00 \\
\text { and } 1.00)\end{array}$ & No effect & [50] \\
\hline
\end{tabular}


Table 5. Cont.

\begin{tabular}{|c|c|c|c|c|c|c|c|c|c|}
\hline \multirow{2}{*}{ Trial No } & \multirow{2}{*}{$\begin{array}{l}\text { Vaccine Formulations, } \\
\text { Antigens, and } \\
\text { Regimens }\end{array}$} & \multirow{2}{*}{$\begin{array}{l}\text { Age of } \\
\text { Chickens at the } \\
\text { End of Study } \\
\text { (Days) }\end{array}$} & \multicolumn{2}{|c|}{$\begin{array}{c}\text { Reductions of } C . \text { jejuni }(\log 10) \\
\text { Colonization in Cecal Contents after } \\
\text { Challenge }{ }^{1}\end{array}$} & \multirow{2}{*}{$\begin{array}{l}\% \text { Colonized } \\
\text { Broilers in the } \\
\text { Vaccinated } \\
\text { Group } \\
\text { (Proportion) }\end{array}$} & \multirow{2}{*}{$\begin{array}{l}\text { \% Colonized } \\
\text { Broilers in the } \\
\text { Control Group } \\
\text { (Proportion) }\end{array}$} & \multirow{2}{*}{$\begin{array}{l}\text { Relative Risk } \\
\quad(95 \% \text { CI })\end{array}$} & \multirow{2}{*}{$\begin{array}{l}\text { Efficacy }(\%)^{7} \\
\text { against } \\
\text { Colonization }\end{array}$} & \multirow{2}{*}{ Reference } \\
\hline & & & $\begin{array}{c}\text { Significant } \\
\text { (Yes/No) }\end{array}$ & $\begin{array}{l}\text { Reduction Levels } \\
\text { (Mean log10 } \\
\text { CFU/gram }{ }^{2} \text { ) } \\
\text { Reported }\end{array}$ & & & & & \\
\hline 26 & $\begin{array}{c}\text { DNA vaccine (prime) } \\
\text { with } 300 \mu \text { g of multiple } \\
\text { DNA proteins (a } \\
\text { combination of purified } \\
\text { YP_001000437.1, FlgL, } \\
\text { FlgK, FliE-1, YP99817.1, } \\
\text { and YP99838.1) cloned } \\
\text { into pcDNA3 plasmids } \\
\text { mixed with } 50 \mu \text { g of } \\
\text { CpG ODN2007 and } \\
\text { subunit vaccine (boost) } \\
\text { with } 100 \mu \text { g of } \\
\text { recombinant multiple } \\
\text { proteins } \\
\text { (YP_001000437.1, FlgL, } \\
\text { FlgK, FliE-1, YP99817.1, } \\
\text { and YP99838.1) } \\
\text { emulsified with } \\
\text { MONTANIDETM ISA70 } \\
\text { VG, intramuscularly } \\
\text { with booster }\end{array}$ & 42 & No & $\begin{array}{l}0.12 \log 10 \\
\text { reduction (No } \\
\text { decrease of } C \text {. } \\
\text { jejuni colonization } \\
\text { reported in the } \\
\text { original paper) } \\
\text { upon } \\
\text { heterologous } \\
\text { challenge }\end{array}$ & $100.0(9 / 9)$ & $100.0(15 / 15)$ & $\begin{array}{l}1.00(1.00 \\
\text { and } 1.00)\end{array}$ & No effect & [50] \\
\hline 27 & $\begin{array}{l}\text { DNA vaccine with } 100 \\
\mu g \text { of purified DNA of } \\
\text { flagellin A protein } \\
\text { (FlaA) cloned into } \\
\text { pcDNA3 plasmid } \\
\text { mixed with } 25 \mu \mathrm{g} \text { of } \\
\text { CpG ODN2007, } \\
\text { subcutaneously } \\
\text { with booster }\end{array}$ & 42 & No & $\begin{array}{l}0.1 \text { geometric } \\
\text { mean } \log 10 \\
\text { reduction }\end{array}$ & $100.0(15 / 15)$ & $100.0(15 / 15)$ & $\begin{array}{l}1.15(0.95 \\
\text { and } 1.41)\end{array}$ & No effect & [51] \\
\hline
\end{tabular}


Table 5. Cont.

\begin{tabular}{|c|c|c|c|c|c|c|c|c|c|}
\hline \multirow{2}{*}{ Trial No } & \multirow{2}{*}{$\begin{array}{l}\text { Vaccine Formulations, } \\
\text { Antigens, and } \\
\text { Regimens }\end{array}$} & \multirow{2}{*}{$\begin{array}{l}\text { Age of } \\
\text { Chickens at the } \\
\text { End of Study } \\
\text { (Days) }\end{array}$} & \multicolumn{2}{|c|}{$\begin{array}{c}\text { Reductions of } C \cdot \text { jejuni }(\log 10) \\
\text { Colonization in Cecal Contents after } \\
\text { Challenge }{ }^{1}\end{array}$} & \multirow{2}{*}{$\begin{array}{l}\% \text { Colonized } \\
\text { Broilers in the } \\
\text { Vaccinated } \\
\text { Group } \\
\text { (Proportion) }\end{array}$} & \multirow{2}{*}{$\begin{array}{l}\text { \% Colonized } \\
\text { Broilers in the } \\
\text { Control Group } \\
\text { (Proportion) }\end{array}$} & \multirow{2}{*}{$\begin{array}{l}\text { Relative Risk } \\
\quad(95 \% \text { CI })\end{array}$} & \multirow{2}{*}{$\begin{array}{c}\text { Efficacy }(\%)^{7} \\
\text { against } \\
\text { Colonization }\end{array}$} & \multirow{2}{*}{ Reference } \\
\hline & & & $\begin{array}{l}\text { Significant } \\
\text { (Yes/No) }\end{array}$ & $\begin{array}{l}\text { Reduction Levels } \\
\text { (Mean log10 } \\
\text { CFU/gram }{ }^{2} \text { ) } \\
\text { Reported }\end{array}$ & & & & & \\
\hline 28 & $\begin{array}{l}\text { DNA vaccine with } 100 \\
\mu \mathrm{g} \text { of purified DNA of } \\
\text { FlaA cloned into } \\
\text { pcDNA3 plasmid } \\
\text { mixed with } 25 \mu \mathrm{g} \text { of } \\
\text { CpG ODN2007, } \\
\text { intramuscularly } \\
\text { with booster }\end{array}$ & 42 & No & $\begin{array}{l}0.2 \text { median } \log 10 \\
\text { reductions }^{3}\end{array}$ & $75.0(12 / 16)$ & $87.5(14 / 16)$ & $\begin{array}{l}0.86(0.61 \\
\text { and } 1.20)\end{array}$ & 14 & [51] \\
\hline 29 & $\begin{array}{l}\text { DNA vaccine (prime) } \\
\text { with } 150 \mu \mathrm{g} \text { of purified } \\
\text { DNA of FlaA into } \\
\text { pcDNA3 plasmid } \\
\text { mixed with } 25 \mu \mathrm{g} \text { of } \\
\text { CpG ODN2007 and } \\
\text { subunit vaccine (boost) } \\
\text { with } 100 \mu \mathrm{g} \text { of } \\
\text { recombinant FlaA } \\
\text { emulsified with } \\
\text { MONTANIDET ISA70 } \\
\text { VG, intramuscularly } \\
\text { with booster }\end{array}$ & 42 & No & No reduction & $100.0(16 / 16)$ & $87.5(14 / 16)$ & $\begin{array}{l}1.14(0.95 \\
\text { and } 1.38)\end{array}$ & No effect & [51] \\
\hline 30 & $\begin{array}{l}\text { Subunit vaccine with } \\
240 \mu \mathrm{g} \text { of recombinant } \\
\text { Campylobacter adhesion } \\
\text { protein to fibronectin } \\
\text { (CadF) }{ }^{8} \text { mixed with } \\
\text { MONTANIDETM ISA } 70 \\
\text { VG, intramuscularly } \\
\text { with booster }\end{array}$ & 27 & Not reported & $\begin{array}{l}1.71 \text { median } \log 10 \\
\text { reductions } 5\end{array}$ & $100.0(11 / 11)$ & $100.0(12 / 12)$ & $\begin{array}{l}1.00(1.00 \\
\text { and } 1.00)\end{array}$ & No effect & [25] \\
\hline
\end{tabular}


Table 5. Cont.

\begin{tabular}{|c|c|c|c|c|c|c|c|c|c|}
\hline \multirow{2}{*}{ Trial No } & \multirow{2}{*}{$\begin{array}{l}\text { Vaccine Formulations, } \\
\text { Antigens, and } \\
\text { Regimens }\end{array}$} & \multirow{2}{*}{$\begin{array}{l}\text { Age of } \\
\text { Chickens at the } \\
\text { End of Study } \\
\text { (Days) }\end{array}$} & \multicolumn{2}{|c|}{$\begin{array}{c}\text { Reductions of } C \cdot \text { jejuni }(\log 10) \\
\text { Colonization in Cecal Contents after } \\
\text { Challenge }{ }^{1}\end{array}$} & \multirow{2}{*}{$\begin{array}{l}\% \text { Colonized } \\
\text { Broilers in the } \\
\text { Vaccinated } \\
\text { Group } \\
\text { (Proportion) }\end{array}$} & \multirow{2}{*}{$\begin{array}{l}\text { \% Colonized } \\
\text { Broilers in the } \\
\text { Control Group } \\
\text { (Proportion) }\end{array}$} & \multirow{2}{*}{$\begin{array}{l}\text { Relative Risk }{ }^{6} \\
\text { (95\% CI) }\end{array}$} & \multirow{2}{*}{$\begin{array}{l}\text { Efficacy }(\%)^{7} \\
\text { against } \\
\text { Colonization }\end{array}$} & \multirow{2}{*}{ Reference } \\
\hline & & & $\begin{array}{l}\text { Significant } \\
\text { (Yes/No) }\end{array}$ & $\begin{array}{l}\text { Reduction Levels } \\
\text { (Mean log10 } \\
\text { CFU/gram }{ }^{2} \text { ) } \\
\text { Reported }\end{array}$ & & & & & \\
\hline 31 & $\begin{array}{l}\text { Subunit vaccine with } \\
240 \mu \mathrm{g} \text { recombinant } \\
\text { FlaA }{ }^{8} \text { mixed with } \\
\text { MONTANIDETM ISA } 70 \\
\text { VG, intramuscularly } \\
\text { with booster }\end{array}$ & 27 & Not reported & $\begin{array}{l}3.35 \text { median log10 } \\
\text { reductions } 5\end{array}$ & $91.7(11 / 12)$ & $100.0(12 / 12)$ & $\begin{array}{l}0.92(0.77 \\
\text { and } 1.09)\end{array}$ & 8 & [25] \\
\hline 32 & $\begin{array}{l}\text { Subunit vaccine with } \\
240 \mu g \text { recombinant } \\
\text { fibronectin-like protein } \\
\text { A (FlpA1) mixed with } \\
\text { MONTANIDETM ISA } 70 \\
\text { VG, intramuscularly } \\
\text { with booster }\end{array}$ & 27 & Not reported & $\begin{array}{l}3.11 \text { median } \log 10 \\
\text { reductions } 5\end{array}$ & $90.0(9 / 10)$ & $100.0(12 / 12)$ & $\begin{array}{l}0.90(0.73 \\
\text { and } 1.11)\end{array}$ & 10 & [25] \\
\hline 33 & $\begin{array}{l}\text { Subunit vaccine with } \\
240 \mu \mathrm{g} \text { recombinant a } \\
\text { component of } \\
\text { multidrug efflux pump } \\
(\mathrm{CmeC})^{8} \text { mixed with } \\
\text { MONTANIDETM ISA } 70 \\
\text { VG, intramuscularly } \\
\text { with booster }\end{array}$ & 27 & Not reported & $\begin{array}{l}\text { No effect of } \\
\text { reduction due to } \\
\text { the widest range } \\
\text { in the level of } \\
\text { colonization } \\
\text { observed by the } \\
\text { authors from the } \\
\text { original paper } \\
\text { (even } 1.37 \text { median } \\
\text { log10 reduction } \\
\text { calculated from } \\
\text { the supplement } \\
\text { table provided }{ }^{5} \text { ) }\end{array}$ & $100.0(12 / 12)$ & $100.0(12 / 12)$ & $\begin{array}{l}1.00(1.00 \\
\text { and } 1.00)\end{array}$ & No effect & [25] \\
\hline
\end{tabular}


Table 5. Cont.

\begin{tabular}{|c|c|c|c|c|c|c|c|c|c|}
\hline \multirow{2}{*}{ Trial No } & \multirow{2}{*}{$\begin{array}{l}\text { Vaccine Formulations, } \\
\text { Antigens, and } \\
\text { Regimens }\end{array}$} & \multirow{2}{*}{$\begin{array}{l}\text { Age of } \\
\text { Chickens at the } \\
\text { End of Study } \\
\text { (Days) }\end{array}$} & \multicolumn{2}{|c|}{$\begin{array}{c}\text { Reductions of } C . j e j u n i(\log 10) \\
\text { Colonization in Cecal Contents after } \\
\text { Challenge }{ }^{1}\end{array}$} & \multirow{2}{*}{$\begin{array}{l}\% \text { Colonized } \\
\text { Broilers in the } \\
\text { Vaccinated } \\
\text { Group } \\
\text { (Proportion) }\end{array}$} & \multirow{2}{*}{$\begin{array}{l}\% \text { Colonized } \\
\text { Broilers in the } \\
\text { Control Group } \\
\text { (Proportion) }\end{array}$} & \multirow{2}{*}{$\begin{array}{l}\text { Relative Risk }{ }^{6} \\
\quad(95 \% \text { CI) }\end{array}$} & \multirow{2}{*}{$\begin{array}{c}\text { Efficacy }(\%)^{7} \\
\text { against } \\
\text { Colonization }\end{array}$} & \multirow{2}{*}{ Reference } \\
\hline & & & $\begin{array}{l}\text { Significant } \\
\text { (Yes/No) }\end{array}$ & $\begin{array}{l}\text { Reduction Levels } \\
\text { (Mean log10 } \\
\text { CFU/gram }{ }^{2} \text { ) } \\
\text { Reported }\end{array}$ & & & & & \\
\hline 34 & $\begin{array}{c}\text { Subunit vaccine of } \\
240 \mu \mathrm{g} \text { a fusion protein } \\
\text { of recombinant } \\
\text { CadF-FlaA-FlpA } 9 \\
\text { mixed with } \\
\text { MONTANIDETM ISA } \\
70 \text { VG, intramuscularly } \\
\text { with booster }\end{array}$ & 27 & Not reported & $\begin{array}{l}3.16 \text { median log10 } \\
\text { reductions } 5\end{array}$ & $77.8(7 / 9)$ & $100.0(12 / 12)$ & $\begin{array}{l}0.78(0.55 \\
\text { and } 1.10)\end{array}$ & 22 & [25] \\
\hline 35 & $\begin{array}{l}10^{8} \text { cells of } E \text {. coli } \\
\text { wzy::kan strain } \\
\text { vectored vaccine } \\
\text { expressing } C \text {. jejuni } \\
\text { protein glycosylation } \\
\text { (N-glycan), orally } \\
\text { with booster }\end{array}$ & 35 & $\begin{array}{l}\text { Yes } \\
\text { Yes }\end{array}$ & 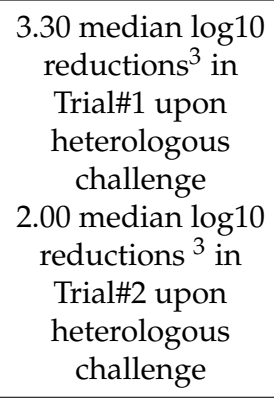 & $60.0(9 / 15)$ & $100.0(15 / 15)$ & $\begin{array}{l}0.60(0.40 \\
\text { and } 0.91)\end{array}$ & 40 & [46] \\
\hline 38 & $\begin{array}{l}\text { Subunit vaccine with } \\
40 \mu \mathrm{g} \text { of recombinant } \\
\text { NHC flagellin mixed } \\
\text { with } 0.4 \mathrm{M} \text { urea, } 10 \mathrm{mM} \\
\text { Tris pH 9.0, } 20 \% \\
\text { glycerol, } 5 \mathrm{mM} \text { sucrose, } \\
\text { in ovo }\end{array}$ & 25 & No & $\begin{array}{l}0.5 \log 10 \\
\text { reduction }\end{array}$ & $88.9(8 / 9)$ & $90.0(9 / 10)$ & $\begin{array}{l}0.99(0.72 \\
\text { and } 1.35)\end{array}$ & 1 & [53] \\
\hline
\end{tabular}


Table 5. Cont.

\begin{tabular}{|c|c|c|c|c|c|c|c|c|c|}
\hline \multirow{2}{*}{ Trial No } & \multirow{2}{*}{$\begin{array}{l}\text { Vaccine Formulations, } \\
\text { Antigens, and } \\
\text { Regimens }\end{array}$} & \multirow{2}{*}{$\begin{array}{l}\text { Age of } \\
\text { Chickens at the } \\
\text { End of Study } \\
\text { (Days) }\end{array}$} & \multicolumn{2}{|c|}{$\begin{array}{c}\text { Reductions of } C . \text { jejuni }(\log 10) \\
\text { Colonization in Cecal Contents after } \\
\text { Challenge }{ }^{1}\end{array}$} & \multirow{2}{*}{$\begin{array}{l}\% \text { Colonized } \\
\text { Broilers in the } \\
\text { Vaccinated } \\
\text { Group } \\
\text { (Proportion) }\end{array}$} & \multirow{2}{*}{$\begin{array}{l}\text { \% Colonized } \\
\text { Broilers in the } \\
\text { Control Group } \\
\text { (Proportion) }\end{array}$} & \multirow{2}{*}{$\begin{array}{l}\text { Relative Risk } \\
\quad(95 \% \text { CI })\end{array}$} & \multirow{2}{*}{$\begin{array}{c}\text { Efficacy }(\%)^{7} \\
\text { against } \\
\text { Colonization }\end{array}$} & \multirow{2}{*}{ Reference } \\
\hline & & & $\begin{array}{c}\text { Significant } \\
\text { (Yes/No) }\end{array}$ & $\begin{array}{l}\text { Reduction Levels } \\
\text { (Mean log10 } \\
\text { CFU/gram }{ }^{2} \text { ) } \\
\text { Reported }\end{array}$ & & & & & \\
\hline 39 & $\begin{array}{l}\text { Subunit vaccine with } \\
20 \mu \mathrm{g} \text { of recombinant } \\
\text { NHC flagellin mixed } \\
\text { with } 0.4 \mathrm{M} \text { urea, } 10 \mathrm{mM} \\
\text { Tris } \mathrm{pH} 9.0,20 \% \\
\text { glycerol, } 5 \mathrm{mM} \text { sucrose, } \\
\text { in ovo }\end{array}$ & 25 & No & No reduction & $90.0(9 / 10)$ & $90.0(9 / 10)$ & $\begin{array}{l}1.00(0.75 \\
\text { and } 1.34)\end{array}$ & No effect & [53] \\
\hline 50 & $\begin{array}{l}\text { Subunit vaccine with } \\
50 \mu \mathrm{g} \text { of recombinant } \\
\text { hemolysin co-regulated } \\
\text { protein (rHcp) mixed } \\
\text { with Freund's } \\
\text { incomplete adjuvant, } \\
\text { orally with booster }\end{array}$ & 35 & Yes & $\begin{array}{c}0.5 \log 10 \\
\text { reduction }\end{array}$ & $100.0(12 / 12)$ & $100.0(12 / 12)$ & $\begin{array}{l}1.00(1.00 \\
\text { and } 1.00)\end{array}$ & No effect & [54] \\
\hline 51 & $\begin{array}{l}\text { Subunit vaccine with } \\
50 \mu \mathrm{g} \text { of rHcp } \\
\text { entrapped in } \\
\text { chitosan-Sodium } \\
\text { tripolyphosphate } \\
\text { nanoparticles (CS-TPP } \\
\text { NPs) (CS-TPP-rhcp), } \\
\text { orally with booster }\end{array}$ & 35 & Yes & $\begin{array}{l}1.0 \log 10 \\
\text { reduction }\end{array}$ & $100.0(12 / 12)$ & $100.0(12 / 12)$ & $\begin{array}{c}1.00(1.00 \text { and } \\
1.00)\end{array}$ & No effect & [54] \\
\hline 52 & $\begin{array}{l}\text { Cell lysate vaccine with } \\
4.3 \mu \mathrm{g} \text { of } C \text {. jejuni cell } \\
\text { lysates, orally }\end{array}$ & 37 & $\begin{array}{l}\text { Yes } \\
\text { Yes }\end{array}$ & $\begin{array}{l}2.14 \log 10 \\
\text { reductions in } \\
\text { Trial\#1 } \\
1.92 \log 10 \\
\text { reductions in } \\
\text { Trial\#2 }\end{array}$ & $100.0(20 / 20)$ & $100.0(19 / 19)$ & $\begin{array}{l}1.00(1.00 \\
\text { and } 1.00)\end{array}$ & No effect & [55] \\
\hline
\end{tabular}


Table 5. Cont.

\begin{tabular}{|c|c|c|c|c|c|c|c|c|c|}
\hline \multirow{2}{*}{ Trial No } & \multirow{2}{*}{$\begin{array}{l}\text { Vaccine Formulations, } \\
\text { Antigens, and } \\
\text { Regimens }\end{array}$} & \multirow{2}{*}{$\begin{array}{l}\text { Age of } \\
\text { Chickens at the } \\
\text { End of Study } \\
\text { (Days) }\end{array}$} & \multicolumn{2}{|c|}{$\begin{array}{c}\text { Reductions of } C \text {. jejuni }(\log 10) \\
\text { Colonization in Cecal Contents after } \\
\text { Challenge }{ }^{1}\end{array}$} & \multirow{2}{*}{$\begin{array}{l}\% \text { Colonized } \\
\text { Broilers in the } \\
\text { Vaccinated } \\
\text { Group } \\
\text { (Proportion) }\end{array}$} & \multirow{2}{*}{$\begin{array}{l}\% \text { Colonized } \\
\text { Broilers in the } \\
\text { Control Group } \\
\text { (Proportion) }\end{array}$} & \multirow{2}{*}{$\begin{array}{c}\text { Relative Risk }{ }^{6} \\
\quad(95 \% \text { CI })\end{array}$} & \multirow{2}{*}{$\begin{array}{c}\text { Efficacy }(\%)^{7} \\
\text { against } \\
\text { Colonization }\end{array}$} & \multirow{2}{*}{ Reference } \\
\hline & & & $\begin{array}{l}\text { Significant } \\
\text { (Yes/No) }\end{array}$ & $\begin{array}{l}\text { Reduction Levels } \\
\text { (Mean log10 } \\
\text { CFU/gram }{ }^{2} \text { ) } \\
\text { Reported }\end{array}$ & & & & & \\
\hline 53 & $\begin{array}{l}\text { Cell lysate vaccine with } \\
21 \mu \mathrm{g} \text { of } C \text {. jejuni cell } \\
\text { lysates, orally }\end{array}$ & 37 & No & $0.7 \log$ reduction ${ }^{3}$ & $100.0(10 / 10)$ & $100.0(9 / 9)$ & $\begin{array}{l}1.00(1.00 \\
\text { and } 1.00)\end{array}$ & No effect & [55] \\
\hline 54 & $\begin{array}{l}\text { Cell lysate vaccine with } \\
4.3 \mu \mathrm{g} \text { of } C \text {. jejuni cell } \\
\text { lysates combined with } 5 \\
\mu \mathrm{g} \text { of } \mathrm{E}-\mathrm{CpG} \text {, orally }\end{array}$ & 37 & $\begin{array}{l}\text { Yes } \\
\text { No }\end{array}$ & $\begin{array}{c}2.42 \log 10 \\
\text { reductions } \\
\text { (compared with } \\
\text { PBS as reported in } \\
\text { the original paper) } \\
1.42 \text { log10 } \\
\text { reductions }{ }^{3} \\
\text { (compared with } \\
\text { E-CpG alone) in } \\
\text { this review as it } \\
\text { was presented in } \\
\text { the figure of the } \\
\text { original paper }\end{array}$ & $100.0(9 / 9)$ & $100.0(10 / 10)$ & $\begin{array}{l}1.00(1.00 \\
\text { and } 1.00)\end{array}$ & No effect & [55] \\
\hline 55 & $\begin{array}{l}\text { Subunit vaccine with } \\
0.2 \text { mg of recombinant } \\
\text { DNA binding protein } \\
\text { for biofilm formation } \\
\text { (Dps) mixed with } \\
\text { Freund's complete } \\
\text { adjuvant, } \\
\text { subcutaneously } \\
\text { with boosters }\end{array}$ & 44 & No & No reduction & $100.0(13 / 13)$ & $100.0(12 / 12)$ & $\begin{array}{l}1.00(1.00 \\
\text { and } 1.00)\end{array}$ & No effect & [56] \\
\hline
\end{tabular}


Table 5. Cont.

\begin{tabular}{|c|c|c|c|c|c|c|c|c|c|}
\hline \multirow{2}{*}{ Trial No } & \multirow{2}{*}{$\begin{array}{l}\text { Vaccine Formulations, } \\
\text { Antigens, and } \\
\text { Regimens }\end{array}$} & \multirow{2}{*}{$\begin{array}{l}\text { Age of } \\
\text { Chickens at the } \\
\text { End of Study } \\
\text { (Days) }\end{array}$} & \multicolumn{2}{|c|}{$\begin{array}{c}\text { Reductions of } C \cdot \text { jejuni }(\log 10) \\
\text { Colonization in Cecal Contents after } \\
\text { Challenge }{ }^{1}\end{array}$} & \multirow{2}{*}{$\begin{array}{l}\% \text { Colonized } \\
\text { Broilers in the } \\
\text { Vaccinated } \\
\text { Group } \\
\text { (Proportion) }\end{array}$} & \multirow{2}{*}{$\begin{array}{l}\text { \% Colonized } \\
\text { Broilers in the } \\
\text { Control Group } \\
\text { (Proportion) }\end{array}$} & \multirow{2}{*}{$\begin{array}{c}\text { Relative Risk } \\
\text { (95\% CI) }\end{array}$} & \multirow{2}{*}{$\begin{array}{l}\text { Efficacy }(\%)^{7} \\
\text { against } \\
\text { Colonization }\end{array}$} & \multirow{2}{*}{ Reference } \\
\hline & & & $\begin{array}{c}\text { Significant } \\
\text { (Yes/No) }\end{array}$ & $\begin{array}{l}\text { Reduction Levels } \\
\text { (Mean log10 } \\
\text { CFU/gram }{ }^{2} \text { ) } \\
\text { Reported }\end{array}$ & & & & & \\
\hline 56 & $\begin{array}{c}\text { Salmonella } \\
\text { Typhimurium strain } \\
\text { x9088 vectored vaccine } \\
\text { (OD600, 0.5 mL) } \\
\text { expressing Dps, orally } \\
\text { with boosters }\end{array}$ & 36 & Yes & $\begin{array}{l}2.48 \text { (geometric } \\
\text { mean) } \log 10 \\
\text { reductions }\end{array}$ & $100.0(14 / 14)$ & $100.0(10 / 10)$ & $\begin{array}{l}1.00(1.00 \\
\text { and } 1.00)\end{array}$ & No effect & [56] \\
\hline 57 & $\begin{array}{c}2 \times 10^{10} \mathrm{CFU} \text { of } \\
\text { Lactobacillus lactis } \\
\text { NZ3900 vectored } \\
\text { vaccine expressing } \\
\text { cysteine ABC } \\
\text { transporter } \\
\text { substrate-binding } \\
\text { protein (CjaA) fused to } \\
\text { heat-labile enterotoxin } \\
\text { B subunit (LTB) of } E \text {. } \\
\text { coli (CjaA-LT-B), orally } \\
\text { with boosters }\end{array}$ & 42 & No & No reduction & $100.0(6 / 6)$ & $100.0(6 / 6)$ & $\begin{array}{l}1.00(1.00 \\
\text { and } 1.00)\end{array}$ & No effect & [57] \\
\hline 58 & $\begin{array}{c}2 \times 10^{10} \text { CFU of } \\
\text { Lactobacillus lactis } \\
\text { NZ3900 vectored } \\
\text { vaccine expressing } \\
\text { CjaA, orally } \\
\text { with boosters }\end{array}$ & 42 & No & No reduction & $100.0(6 / 6)$ & $100.0(6 / 6)$ & $\begin{array}{l}1.00(1.00 \\
\text { and } 1.00)\end{array}$ & No effect & [57] \\
\hline
\end{tabular}


Table 5. Cont.

\begin{tabular}{|c|c|c|c|c|c|c|c|c|c|}
\hline \multirow{2}{*}{ Trial No } & \multirow{2}{*}{$\begin{array}{l}\text { Vaccine Formulations, } \\
\text { Antigens, and } \\
\text { Regimens }\end{array}$} & \multirow{2}{*}{$\begin{array}{l}\text { Age of } \\
\text { Chickens at the } \\
\text { End of Study } \\
\text { (Days) }\end{array}$} & \multicolumn{2}{|c|}{$\begin{array}{c}\text { Reductions of } C . \text { jejuni }(\log 10) \\
\text { Colonization in Cecal Contents after } \\
\text { Challenge }{ }^{1}\end{array}$} & \multirow{2}{*}{$\begin{array}{l}\text { \% Colonized } \\
\text { Broilers in the } \\
\text { Vaccinated } \\
\text { Group } \\
\text { (Proportion) }\end{array}$} & \multirow{2}{*}{$\begin{array}{l}\text { \% Colonized } \\
\text { Broilers in the } \\
\text { Control Group } \\
\text { (Proportion) }\end{array}$} & \multirow{2}{*}{$\begin{array}{l}\text { Relative Risk }{ }^{6} \\
\quad(95 \% \text { CI) }\end{array}$} & \multirow{2}{*}{$\begin{array}{l}\text { Efficacy }(\%)^{7} \\
\text { against } \\
\text { Colonization }\end{array}$} & \multirow{2}{*}{ Reference } \\
\hline & & & $\begin{array}{l}\text { Significant } \\
\text { (Yes/No) }\end{array}$ & $\begin{array}{l}\text { Reduction Levels } \\
\text { (Mean log10 } \\
\text { CFU/gram }{ }^{2} \text { ) } \\
\text { Reported }\end{array}$ & & & & & \\
\hline 59 & $\begin{array}{c}10^{8} \text { cells of avirulent } \\
\text { Salmonella } \\
\text { Typhimurium } \times 3987 \\
\text { strain vectored vaccine } \\
\left(10^{8} \text { cells) expressing }\right. \\
\text { CjaA, orally } \\
\text { with boosters }\end{array}$ & 40 & Yes & $\begin{array}{l}6.0 \log 10 \\
\text { reductions } \\
\text { (reported in the } \\
\text { original paper) } \\
\text { upon } \\
\text { heterologous } \\
\text { challenge }\end{array}$ & $0.0(0 / 4)$ & $100.0(3 / 3)$ & $\begin{array}{l}0.11(0.01 \\
\text { and } 1.63)\end{array}$ & 89 & [26] \\
\hline 63 & $\begin{array}{l}\text { Subunit vaccine with } 1 \\
\text { mg of CjaA-LT-B mixed } \\
\text { with sodium carbonate, } \\
\text { orally with booster }\end{array}$ & 35 & No reported & Not reported & $27.6(40 / 145)$ & $49.3(70 / 142)$ & $\begin{array}{l}0.56(0.41 \\
\text { and } 0.76)\end{array}$ & 44 & [78] \\
\hline
\end{tabular}


Twenty trials from seven papers reported non-significant (geometric, arithmetic, or median) $\log 10$ reduction (CFU/g or GenEq/g) upon homologous/heterologous challenge. The levels of $\log 10$ reduction from 15 of 20 trials were reported between 0.1 and 1.6 (mean or median) $\log 10$ reduction after homologous challenge. These trials were the crude lysate vaccines with OMP, OMP-NP orally with booster [47], DNA vaccine with purified FlaA cloned into pcDNA3 plasmids mixed with adjuvant subcutaneously or intramuscularly with booster [51], formalin-killed whole-cell vaccine mixed with oil adjuvants [52], subunit vaccine with $40 \mu \mathrm{g}$ of recombinant NHC flagellin mixed adjuvant in ovo [53], and SE vectored vaccine expressing Omp18 protein (Cj0013), peptidoglycan associated lipoprotein of Salmonella (PAL of Salmonella), and high mobility group box 1 protein (HMGB1) orally [58]. Five trial used a combination of DNA (prime) and subunit (boost) vaccine with four individual antigens and combinations of these antigens, delivered intramuscularly with booster upon heterologous challenge reported reduction levels ranging between 0.12 and $2.2 \log 10 \mathrm{CFU} / \mathrm{g}$ (using qPCR or bacterial culture methods) and between 1.06 and $1.92 \log 10$ reductions in genome equivalents per gram (qPCR) [50].

Of further note, nine trials using hypothetical protein YP99817.1 in DNA (prime) and subunit (boost), $20 \mu \mathrm{g}$ of recombinant flagellin-NHC mixed adjuvant in subunit vaccine in ovo, and L. lactis NZ3900 vectored vaccine expressing CjaA and heat-labile enterotoxin B subunit (LTB) of E. coli (CjaA-LTB) failed to reduce C. jejuni colonization [50,53,56,57].

\subsection{Prevalence of Colonized Broilers in Vaccine Efficacy}

To further evaluate vaccine performance in this review, the trial outputs from eligible studies were used to estimate vaccine efficacy using relative risks to enable comparisons to be made between studies. A wide range of vaccine efficacies in vaccinated broilers was identified, ranging from no effect of $C$. jejuni colonization to $100.0 \%$ prevention (Table 5). Of 45 eligible vaccine trials, three trials reported C. jejuni detection was unculturable (below detection limit) in all vaccinated broilers after homologous challenge $(R R<0.11)$ and vaccine efficacy was approximately $90 \%$.The three trials were $125 \mu \mathrm{g}$ of crude cell lysate vaccine with total OMP (subcutaneously with booster), $125 \mu \mathrm{g}$ of crude cell lysate vaccine with total OMP encapsulated with lactide-co-glycolide nanoparticles (subcutaneously with booster), and $10^{8}$ cells of an avirulent Salmonella enterica $\chi 3987$ strain vectored vaccine expressing CjaA (orally with booster). Following these, one trial using a subunit vaccine with recombinant FlaA-LT-B mixed with sodium carbonate reported a significant reduction of the number of colonized vaccinated broilers after heterologous challenge with the prevalence of $27.6 \%$ [78] but the efficacy was $44 \%$ (Table 5).

In contrast, 28 trials failed to prevent $C$. jejuni colonization as all vaccinated broilers were positive of $C$. jejuni with a relative risk of $\geq 1.00$ (Table 5). Based on a comparison of $\log 10 \mathrm{CFU} / \mathrm{g}$ reductions, 10 trials report significant $\log 10$ reductions between 0.5 and $4.2 \log 10 \mathrm{CFU} / \mathrm{g}$ and 10 trials were non-significant $\log 10$ reductions ranging between 0.1 and $2.2 \log 10$. While six and two trials were non-reduction and not reported, respectively (Table 5).

\section{Discussion}

The development of efficacious C. jejuni vaccines for poultry is potentially an effective intervention strategy to reduce the risk of campylobacter infections in humans. In this review, our goal was to evaluate the results of published C. jejuni vaccine studies with the view to identifying the most efficacious antigens for further development. The effective outcomes of controlling C. jejuni at farms are commonly evaluated using the reduction of prevalence (proportion) of colonized broilers or the reduction of C. jejuni loads in the intestine. When undertaking this review, it became apparent that the variability of how C. jejuni vaccine studies have been reported prevent direct comparisons of vaccine efficacy from being made. Most studies report the outcome of vaccination as either antigen-specific immune responses and/or reductions of the C. jejuni loads in the intestines $[22,25,45,47-51,54,55,79-82]$. While many studies report significant reductions 
in C. jejuni loads, the actual reductions are highly variable. Consequently, it is difficult to estimate the potential impacts of these studies on the risk of $C$. jejuni transmission to humans.

Based on this review, 62 trials from 16 papers fulfilled the selection criteria and were included using C. jejuni loads in vaccinated broilers [24-26,46-58]. The variations of $C$. jejuni $\log 10$ reduction within these studies were estimated from different C. jejuni loads $(\log 10)$ in ceca between vaccinated and non-vaccinated chickens [49,50,80,82]. High variations of significant $\log 10$ reductions of $C$. jejuni loads in the intestines of vaccinated broilers were reported between 0.5 and $6.0 \log 10$ reductions among the studies using different variables for statistical comparisons (i.e., geometric mean, arithmetic mean, or median) [25,26,49,50,54-56]. Highly variable data of C. jejuni loads in the individual vaccinated broilers were reported in some trials of the original papers was identified in this review $[25,50]$. In some cases, where levels of $\log 10$ reductions were identified, the outcomes of vaccine efficacy were reported as non-significant reduction or no decrease in C. jejuni colonization $[25,50]$. While other studies reported levels of CFU/g reduction of $C$. jejuni colonization between $\sim 0.5$ and $\sim 1.9$ were significant $[49,54,55]$, other studies reported similar reductions $(<1.9 \log 10 \mathrm{CFU} / \mathrm{g})$ as non-significant $[25,50,58]$. These suggest that the statistical power of some studies was insufficient to discriminate between treatment groups where the log10 reductions of colonization were modest. Nauta et al. [10] estimated that a one or two log10 reduction of Campylobacter loads in cecal contents of broilers at slaughterhouses could potentially reduce the risk of transmission to humans by at least $44 \%$. Therefore, more studies are needed to define the vaccine trial parameters required to enable the robust measurement of $\log 10$ reductions and how these reductions impact on the risk of human transmission. Defining these parameters is important as assessing the efficacy of C. jejuni vaccines as it is likely to remain reliant on challenge studies. Several studies have reported poor correlations between immune responses and reductions in the $C$. jejuni loads in the intestines of chickens in vaccination/challenge studies $[22,25,45,47,50,51,54,79,81,82]$.

As a result of these factors, the quantitative risk assessment model reported by Rosenquist et al. [34] was adopted for this review. The model predicts that a 30-fold reduction in the broiler flock prevalence of $C$. jejuni would result in a 2-log10 reduction of carcass contamination. The outcome of reducing carcass contamination by this amount could result in a 30-fold decrease in the incidence of human campylobacteriosis. Similarly, EFSA [9] using a model for C. jejuni prevalence targets to analyse the quantitative microbiological risk assessment estimated that setting targets of $25 \%$ and $5 \%$ between broiler flock prevalence would reduce to $50 \%$ and $90 \%$ of the public health risk, respectively. Thus, these models enable the critical evaluation of published vaccine efficacy studies in the context of public health outcomes. Consequently, in this review, we used the proportionate number (prevalence) of C. jejuni positive/negative broiler chickens between vaccinated and unvaccinated after challenge to evaluate the included studies as another definition of vaccine efficacy. The prevalence of colonized broilers was taken from the text/tabulations reported and/or estimated from figures provided in the original papers. Consequently, a total of 45 trials from 13 papers fulfilled the inclusion criteria [25,26,46-48,50,51,53-57,78]. This highlights the need for future studies to consider the models of Rosenquist et al. [34] and EFSA [9] to determine the impact of reducing C. jejuni loads in ceca of chickens on the risk of carcass contamination. When considering the vaccine efficacy based upon prevalence, OMP, OMP-NP, and CjaA antigens from three different vaccine trials (crude cell lysate and avirulent ST $\chi 3987$ strain vectored vaccines) were demonstrated to clear C. jejuni colonization in the vaccinated broilers with $R R<0.11$ and vaccine efficacy greater than $90 \%$, compared with the control groups. These outcomes were comparable to significant levels between 5.7 and $6.0 \log 10$ reductions reported. Following this, a subunit vaccine with $1 \mathrm{mg}$ of recombinant FlaA-LT-B mixed with sodium carbonate reported significant reductions in the number of colonized broiler with prevalence of $27.59 \%$ [78], but the RR was 0.56 with the vaccine efficacy of $44 \%$. Thus, based on the data reviewed using both 
definitions of vaccine efficacy, significant reduction levels more than $5.7 \log 10$ reductions could provide the vaccine efficacy more than $90 \%$.

One of the potential challenges for using vaccination to control $C$. jejuni colonization is the lifespan of commercial broilers. The current review identified that the many eligible vaccine efficacy studies used broilers with a wide age range, ranging from 24 to 46 days by the end of the study (Tables 3 and 5). Commercial broiler chickens are commonly slaughtered between 35 and 86 days of age, depending on the target market weight and the type of farming system $[83,84]$. It has been reported that chicken B cell populations do not fully mature until 42 days of age, which may also affect vaccine efficacy [85]. Chicken age is of further importance to vaccine efficacy with respect to timing of $C$. jejuni colonization. Recent studies have reported that commercial broilers were colonized by $C$. jejuni and/or C. coli by 10 days of age [86,87], suggesting that vaccination of chicks would be of benefit to the poultry industry. However, maternal antibodies can interfere with vaccine efficacy when live vectored vaccines are applied in young chicks [88]. To overcome this issue, a subunit vaccine or a vectored vaccine with various routes of immunization (i.e., intranasal or in ovo) that are not neutralized by maternal antibodies would be worthwhile exploring [89-91]. Thus, the ideal C. jejuni vaccine will need to confer rapid immune responses to antigens associated with preventing colonization and provide protection to chickens from early in the production cycle through to slaughter.

Based upon the inclusion/exclusion criteria of this review using the prevalence of colonized broilers, a meta-analysis could not be performed due to highly variable data. Thus, it is recommended that future studies reporting $C$. jejuni efficacy studies are supported by datasets that include, the numbers of colonized/non-colonized broiler chickens in treatment groups. Where the outcomes of trials are reported as a degree of colonization (e.g., CFU/g of fecal matter) individual chicken data should be reported to enable future meta-analyses of vaccine studies.

The compiled dataset of published C. jejuni poultry vaccine studies reviewed here has highlighted the highly variable nature of how these prototype vaccines have been evaluated and reported. However, it is clear from the results of these vaccine studies, some of these could potentially lead to a commercial vaccine in the future. Thus, it is recommended that a standardized evaluation model and reporting system be developed for C. jejuni vaccination studies. The standardized evaluation model would need to include, bird type (e.g., broiler and layer), age of bird, type of vaccine, antigen (source and dose), type of adjuvant where applicable, route of vaccination, method of challenge, time to challenge, and challenge dose(s) being the minimal reporting requirements. In terms of evaluating efficacy, while various outcomes would be acceptable, such as protected/not protected or reductions in colonization loads, based on bacterial culture and/or molecular (i.e., quantitative PCR or mass spectrometry) detection, it is crucial that individual bird data should be made readily available. Standardization, particularly of efficacy trial outcome reporting, would enable a more robust evaluation of putative antigens and their formulations between studies.

\section{Conclusions}

Of the C. jejuni antigens evaluated in this study, it was concluded that the OMP $(125 \mu \mathrm{g})$ formulated with and without PLGA-NP delivered subcutaneously and the oral vaccination with subunit vaccine with recombinant FlaA-LT-B mixed with sodium carbonate were the most efficacious candidate vaccines to reduce $C$. jejuni colonization of broilers identified to date. Further evaluation of this "antigen complex" is clearly warranted, perhaps using OMP preparations from gene deletion mutants to identify which components are contributing to the protection, using the proposed evaluation model described above. Overall, the data assessed in this review supports the conclusion that the development of a C. jejuni vaccine to prevent the colonization of poultry is feasible. Such a vaccine would be crucial in helping the global poultry industry minimize risks to the consumers of their products. 
Author Contributions: Conceptualization, T.V.; methodology, P.P.-o.; formal analysis, P.P.-o.; data curation, P.P.-o.; validation, P.P.-o., T.V., T.J.M. and R.A.H.; writing-original draft preparation, P.P.-o.; writing-review and editing, P.P.-o., T.V., T.J.M. and R.A.H.; visualization, P.P.-o. All authors have read and agreed to the published version of the manuscript.

Funding: This research received no external funding.

Institutional Review Board Statement: Not applicable.

Informed Consent Statement: Not applicable.

Data Availability Statement: The primary datasets extracted from the manuscripts included in this review were tabulated and summarized in Microsoft Excel. These files are available upon request to the corresponding author.

Acknowledgments: We thank Gang Xie for assistance and advice on R analyses.

Conflicts of Interest: The authors declare no conflict of interest.

\section{References}

1. Kaakoush, N.O.; Castaño-Rodríguez, N.; Mitchell, H.M.; Man, S.M. Global Epidemiology of Campylobacter Infection. Clin. Microbiol. Rev. 2015, 28, 687-720. [CrossRef] [PubMed]

2. Igwaran, A.; Okoh, A.I. Human campylobacteriosis: A public health concern of global importance. Heliyon 2019,5 , e02814. [CrossRef] [PubMed]

3. EFSA, The European Union summary report on trends and sources of zoonoses, zoonotic agents and food-borne outbreaks in 2015. EFSA J. 2016, 14, 4634.

4. Moffatt, C.R.; Fearnley, E.; Bell, R.; Wright, R.; Gregory, J.; Sloan-Gardner, T.; Kirk, M.; Stafford, R. Characteristics of Campylobacter Gastroenteritis Outbreaks in Australia, 2001 to 2016. Foodborne Pathog. Dis. 2020, 17, 308-315. [CrossRef] [PubMed]

5. EFSA, Scientific Opinion on Quantification of the risk posed by broiler meat to human campylobacteriosis in the EU. EFSA J. 2010, 8, 1437. [CrossRef]

6. O'Leary, M.C.; Harding, O.; Fisher, L.; Cowden, J. A continuous common-source outbreak of campylobacteriosis associated with changes to the preparation of chicken liver pâté. Epidemiol. Infect. 2008, 137, 383-388. [CrossRef]

7. Meade, K.G.; Narciandi, F.; Cahalane, S.; Reiman, C.; Allan, B.; O’Farrelly, C. Comparative in vivo infection models yield insights on early host immune response to Campylobacter in chickens. Immunogenetics 2008, 61, 101-110. [CrossRef]

8. Romero-Barrios, P.; Hempen, M.; Messens, W.; Stella, P.; Hugas, M. Quantitative microbiological risk assessment (QMRA) of food-borne zoonoses at the European level. Food Control. 2013, 29, 343-349. [CrossRef]

9. EFSA, Scientific Opinion on Campylobacterin broiler meat production: Control options and performance objectives and/or targets at different stages of the food chain. EFSA J. 2011, 9, 2105. [CrossRef]

10. Nauta, M.J.; Johannessen, G.; Adame, L.L.; Williams, N.; Rosenquist, H. The effect of reducing numbers of Campylobacter in broiler intestines on human health risk. Microb. Risk Anal. 2016, 68-77. [CrossRef]

11. Smith, S.; Messam, L.L.; Meade, J.; Gibbons, J.; McGill, K.; Bolton, D.; Whyte, P. The impact of biosecurity and partial depopulation on Campylobacter prevalence in Irish broiler flocks with differing levels of hygiene and economic performance. Infect. Ecol. Epidemiol. 2016, 6, 31454. [CrossRef] [PubMed]

12. Solis de los Santos, F.; Donoghue, A.M.; Venkitanarayanan, K.; Metcalf, J.H.; Reyes-Herrera, I.; Dirain, M.L.; Aguiar, V.F.; Blore, P.J.; Donoghue, D.J. The natural feed additive caprylic acid decreases Campylobacter jejuni colonization in market-aged broiler chickens. Poult. Sci. 2009, 88, 61-64. [CrossRef] [PubMed]

13. Skånseng, B.; Kaldhusdal, M.; Moen, B.; Gjevre, A.-G.; Johannessen, G.; Sekelja, M.; Trosvik, P.; Rudi, K. Prevention of intestinal Campylobacter jejuni colonization in broilers by combinations of in-feed organic acids. J. Appl. Microbiol. 2010, 109, 1265-1273. [CrossRef]

14. Hermans, D.; Martel, A.; Van Deun, K.; Verlinden, M.; Van Immerseel, F.; Garmyn, A.; Messens, W.; Heyndrickx, M.; Haesebrouck, F.; Pasmans, F. Intestinal mucus protects Campylobacter jejuni in the ceca of colonized broiler chickens against the bactericidal effects of medium-chain fatty acids. Poult. Sci. 2010, 89, 1144-1155. [CrossRef] [PubMed]

15. Metcalf, J.H.; Donoghue, A.M.; Venkitanarayanan, K.; Reyes-Herrera, I.; Aguiar, V.F.; Blore, P.J.; Donoghue, D.J. Water administration of the medium-chain fatty acid caprylic acid produced variable efficacy against enteric Campylobacter colonization in broilers1,2. Poult. Sci. 2011, 90, 494-497. [CrossRef] [PubMed]

16. Kittler, S.; Fischer, S.; Abdulmawjood, A.; Glünder, G.; Klein, G. Effect of Bacteriophage Application on Campylobacter jejuni Loads in Commercial Broiler Flocks. Appl. Environ. Microbiol. 2013, 79, 7525-7533. [CrossRef]

17. Ghareeb, K.; Awad, W.A.; Mohnl, M.; Porta, R.; Biarnés, M.; Böhm, J.; Schatzmayr, G. Evaluating the efficacy of an avian-specific probiotic to reduce the colonization ofCampylobacter jejuni in broiler chickens. Poult. Sci. 2012, 91, 1825-1832. [CrossRef]

18. Saint-Cyr, M.J.; Haddad, N.; Taminiau, B.; Poezevara, T.; Quesne, S.; Amelot, M.; Daube, G.; Chemaly, M.; Dousset, X.; GuyardNicodème, M. Use of the potential probiotic strain Lactobacillus salivarius SMXD51 to control Campylobacter jejuni in broilers. Int. J. Food Microbiol. 2017, 247, 9-17. [CrossRef] 
19. Stern, N.J.; Eruslanov, B.V.; Pokhilenko, V.D.; Kovalev, Y.N.; Volodina, L.L.; Perelygin, V.V.; Mitsevich, E.V.; Mitsevich, I.P.; Borzenkov, V.N.; Levchuk, V.P.; et al. Bacteriocins reduce Campylobacter jejuni colonization while bacteria producing bacteriocins are ineffective. Microb. Ecol. Heal. Dis. 2008, 20, 74-79. [CrossRef]

20. Buckley, A.M.; Wang, J.; Hudson, D.L.; Grant, A.J.; Jones, M.A.; Maskell, D.J.; Stevens, M.P. Evaluation of live-attenuated Salmonella vaccines expressing Campylobacter antigens for control of C. jejuni in poultry. Vaccine 2010, 28, 1094-1105. [CrossRef]

21. Łaniewski, P.; Lis, M.; Wyszyńska, A.; Majewski, P.; Godlewska, R.; Jagusztyn-Krynicka, E.K. Assessment of chicken protection against Campylobacter jejuni infection by immunization with avirulent Salmonella enterica sv. Typhimurium strain producing Campylobacter CjaD/Pal protein. Vaccine Dev. Ther. 2012, 43. [CrossRef]

22. Layton, S.L.; Morgan, M.J.; Cole, K.; Kwon, Y.M.; Donoghue, D.J.; Hargis, B.M.; Pumford, N.R. Evaluation of Salmonella-vectored Campylobacter peptide epitopes for reduction of Campylobacter jejuni in broiler chickens. Clin. Vaccine Immunol. 2011, 18, 449-454. [CrossRef] [PubMed]

23. Rickaby, B.; Eng, N.F.; Flint, A.; Stintzi, A.; Diaz-Mitoma, F. The Application of a Proteoliposome Adjuvant System in the Development of a Campylobacter jejuni Vaccine. Procedia Vaccinol. 2015, 9, 38-43. [CrossRef]

24. Saxena, M.; John, B.; Mu, M.; Van, T.T.H.; Taki, A.; Coloe, P.J.; Smooker, P.M. Strategies to Reduce Campylobacter Colonisation in Chickens. Procedia Vaccinol. 2013, 7, 40-43. [CrossRef]

25. Neal-McKinney, J.M.; Samuelson, D.R.; Eucker, T.P.; Nissen, M.S.; Crespo, R.; Konkel, M.E. Reducing Campylobacter jejuni Colonization of Poultry via Vaccination. PLoS ONE 2014, 9, e114254. [CrossRef] [PubMed]

26. Wyszyńska, A.; Raczko, A.; Lis, M.; Jagusztyn-Krynicka, E.K. Oral immunization of chickens with avirulent Salmonella vaccine strain carrying C. jejuni $72 \mathrm{Dz} / 92 \mathrm{cjaA}$ gene elicits specific humoral immune response associated with protection against challenge with wild-type Campylobacter. Vaccine 2004, 22, 1379-1389. [CrossRef] [PubMed]

27. Clark, J.D.; Oakes, R.D.; Redhead, K.; Crouch, C.F.; Francis, M.J.; Tomley, F.M.; Blake, D.P. Eimeria species parasites as novel vaccine delivery vectors: Anti-Campylobacter jejuni protective immunity induced by Eimeria tenella-delivered CjaA. Vaccine 2012, 30, 2683-2688. [CrossRef] [PubMed]

28. Zeng, X.; Xu, F.; Lin, J. Development and Evaluation of CmeC Subunit Vaccine against Campylobacter jejuni. J. Vaccines Vaccin. 2010, 1,1 .

29. Rice, B.E.; Rollins, D.M.; Mallinson, E.T.; Carr, L.; Joseph, S.W. Campylobacter jejuni in broiler chickens: Colonization and humoral immunity following oral vaccination and experimental infection. Vaccine 1997, 15, 1922-1932. [CrossRef]

30. Łaniewski, P.; Kuczkowski, M.; Chrząstek, K.; Woźniak, A.; Wyszyńska, A.; Wieliczko, A.; Jagusztyn-Krynicka, E.K. Evaluation of the immunogenicity of Campylobacter jejuni CjaA protein delivered by Salmonella enterica sv. Typhimurium strain with regulated delayed attenuation in chickens. World J. Microbiol. Biotechnol. 2013, 30, 281-292. [CrossRef]

31. Moher, D.; Shamseer, L.; Clarke, M.G.D.; Liberati, A.; Petticrew, M.; Shekelle, P.; Stewart, L.A.; Group, P.-P. Preferred reporting items for systematic review and meta-analysis protocols (PRISMA-P) 2015 statement. Syst. Rev. 2015, 4, 1. [CrossRef]

32. Han, Z.; Willer, T.; Pielsticker, C.; Gerzova, L.; Rychlik, I.; Rautenschlein, S. Differences in host breed and diet influence colonization by Campylobacter jejuni and induction of local immune responses in chicken. Gut Pathog. 2016, 8, 1-14. [CrossRef]

33. Humphrey, S.; Chaloner, G.; Kemmett, K.; Davidson, N.; Williams, N.; Kipar, A.; Humphrey, T.; Wigley, P. Campylobacter jejuni Is Not Merely a Commensal in Commercial Broiler Chickens and Affects Bird Welfare. mBio 2014, 5, e01364-14. [CrossRef]

34. Rosenquist, H.; Nielsen, N.L.; Sommer, H.M.; Nørrung, B.; Christensen, B.B. Quantitative risk assessment of human campylobacteriosis associated with thermophilic Campylobacter species in chickens. Int. J. Food Microbiol. 2003, 83, 87-103. [CrossRef]

35. De la Cruz, M.; Conrado, I.; Nault, A.; Perez, A.; Dominguez, L.; Alvarez, J. Vaccination as a control strategy against Salmonella infection in pigs: A systematic review and meta-analysis of the literature. Res. Veter. Sci. 2017, 114, 86-94. [CrossRef]

36. Osterholm, M.T.; Kelley, N.S.; Sommer, A.; Belongia, A.E. Efficacy and effectiveness of influenza vaccines: A systematic review and meta-analysis. Lancet Infect. Dis. 2012, 12, 36-44. [CrossRef]

37. Lund, M.; Nordentoft, S.; Pedersen, K.; Madsen, M. Detection of Campylobacter spp. in Chicken Fecal Samples by Real-Time PCR. J. Clin. Microbiol. 2004, 42, 5125-5132. [CrossRef] [PubMed]

38. Weinberg, G.A.; Szilagyi, P.G. Vaccine Epidemiology: Efficacy, Effectiveness, and the Translational Research Roadmap. J. Infect. Dis. 2010, 201, 1607-1610. [CrossRef] [PubMed]

39. Hsu, S.-M.; Chen, T.H.-H.; Wang, C.-H. Efficacy of Avian Influenza Vaccine in Poultry: A Meta-analysis. Avian Dis. 2010, 54, 1197-1209. [CrossRef]

40. Bewick, V.; Cheek, L.; Ball, J. Statistics review 11: Assessing risk. Crit. Care 2004, 8, 287-291. [CrossRef]

41. Engels, E.A.; E Falagas, M.; Lau, J.; Bennish, M.L. Typhoid fever vaccines: A meta-analysis of studies on efficacy and toxicity. BMJ 1998, 316, 110-116. [CrossRef]

42. Basta, N.E.; Halloran, M.E.; Matrajt, L.; Longini, I.M. Estimating Influenza Vaccine Efficacy From Challenge and Community-based Study Data. Am. J. Epidemiol. 2008, 168, 1343-1352. [CrossRef]

43. R Core Team. R: A Language and Environment for Statistical Computing; R Foundation for Statistical Computing: Vienna, Austria, 2018; Available online: https: / / www.R-project.org (accessed on 1 February 2021).

44. Adams, L.J.; Zeng, X.; Lin, J. Development and Evaluation of Two Live Salmonella-Vectored Vaccines for Campylobacter Control in Broiler Chickens. Foodborne Pathog. Dis. 2019, 16, 399-410. [CrossRef]

45. Liu, X.; Adams, L.J.; Zeng, X.; Lin, J. Evaluation of in ovo vaccination of DNA vaccines for Campylobacter control in broiler chickens. Vaccine 2019, 37, 3785-3792. [CrossRef] 
46. Nothaft, H.; Perez-Munoz, M.E.; Gouveia, G.J.; Duar, R.M.; Wanford, J.J.; Lango-Scholey, L.; Panagos, C.G.; Srithayakumar, V.; Plastow, G.S.; Coros, C.; et al. Co-administration of the Campylobacter jejuni N-glycan based vaccine with probiotics improves vaccine performance in broiler chickens. Appl. Environ. Microbiol. 2017, 83, e01523-17. [CrossRef]

47. Annamalai, T.; Pina-Mimbela, R.; Kumar, A.; Binjawadagi, B.; Liu, Z.; Renukaradhya, G.J.; Rajashekara, G. Evaluation of nanoparticle-encapsulated outer membrane proteins for the control of Campylobacter jejuni colonization in chickens. Poult. Sci. 2013, 92, 2201-2211. [CrossRef]

48. Gorain, C.; Singh, A.; Bhattacharyya, S.; Kundu, A.; Lahiri, A.; Gupta, S.; Mallick, A.I. Mucosal delivery of live Lactococcus lactis expressing functionally active JlpA antigen induces potent local immune response and prevent enteric colonization of Campylobacter jejuni in chickens. Vaccine 2020, 38, 1630-1642. [CrossRef]

49. Hodgins, D.C.; Barjesteh, N.; Paul, M.S.; Ma, Z.; A Monteiro, M.; Sharif, S. Evaluation of a polysaccharide conjugate vaccine to reduce colonization by Campylobacter jejuni in broiler chickens. BMC Res. Notes 2015, 8, 1-8. [CrossRef] [PubMed]

50. Meunier, M.; Guyard-Nicodème, M.; Vigouroux, E.; Poezevara, T.; Beven, V.; Quesne, S.; Bigault, L.; Amelot, M.; Dory, D.; Chemaly, M. Promising new vaccine candidates against Campylobacter in broilers. PLoS ONE 2017, 12, e0188472. [CrossRef] [PubMed]

51. Meunier, M.; Guyard-Nicodème, M.; Vigouroux, E.; Poezevara, T.; Béven, V.; Quesne, S.; Amelot, M.; Parra, A.; Chemaly, M.; Dory, D. A DNA prime/protein boost vaccine protocol developed against Campylobacter jejuni for poultry. Vaccine 2018, 36, 2119-2125. [CrossRef] [PubMed]

52. Okamura, M.; Tominaga, A.; Ueda, M.; Ohshima, R.; Kobayashi, M.; Tsukada, M.; Yokoyama, E.; Takehara, K.; Deguchi, K.; Honda, T.; et al. Irrelevance between the Induction of Anti-Campylobacter Humoral Response by a Bacterin and the Lack of Protection against Homologous Challenge in Japanese Jidori Chickens. J. Veter Med. Sci. 2012, 74, 75-78. [CrossRef]

53. Radomska, K.A.; Vaezirad, M.M.; Verstappen, K.M.; Wösten, M.M.S.M.; Wagenaar, J.A.; Van Putten, J.P.M. Chicken Immune Response after In Ovo Immunization with Chimeric TLR5 Activating Flagellin of Campylobacter jejuni. PLoS ONE 2016, 11, e0164837. [CrossRef]

54. Singh, A.; Nisaa, K.; Bhattacharyya, S.; Mallick, A.I. Immunogenicity and protective efficacy of mucosal delivery of recombinant hcp of Campylobacter jejuni Type VI secretion system (T6SS) in chickens. Mol. Immunol. 2019, 111, 182-197. [CrossRef]

55. Taha-Abdelaziz, K.; Hodgins, D.C.; Alkie, T.N.; Quinteiro-Filho, W.; Yitbarek, A.; Astill, J.; Sharif, S. Oral administration of PLGA-encapsulated CpG ODN and Campylobacter jejuni lysate reduces cecal colonization by Campylobacter jejuni in chickens. Vaccine 2018, 36, 388-394. [CrossRef]

56. Theoret, J.R.; Cooper, K.K.; Zekarias, B.; Roland, K.L.; Law, B.F.; Curtiss, R., 3rd; Joens, L.A. The Campylobacter jejuni Dps homologue is important for in vitro biofilm formation and cecal colonization of poultry and may serve as a protective antigen for vaccination. Clin. Vaccine Immunol. 2012, 19, 1426-1431. [PubMed]

57. Wang, C.; Zhou, H.; Guo, F.; Yang, B.; Su, X.; Lin, J.; Xu, F. Oral Immunization of Chickens with Lactococcus lactis Expressing cjaA Temporarily Reduces Campylobacter jejuni Colonization. Foodborne Pathog. Dis. 2020, 17, 366-372. [CrossRef]

58. Yang, Y.; Wolfenden, A.; Mandal, R.K.; Faulkner, O.; Hargis, B.; Kwon, Y.M.; Bielke, L. Evaluation of recombinant Salmonella vaccines to provide cross-serovar and cross-serogroup protection. Poult. Sci. 2017, 96, 4352-4360. [CrossRef] [PubMed]

59. Kakuda, T.; DiRita, V.J. Cj1496c Encodes a Campylobacter jejuni Glycoprotein That Influences Invasion of Human Epithelial Cells and Colonization of the Chick Gastrointestinal Tract. Infect. Immun. 2006, 74, 4715-4723. [CrossRef]

60. Konkel, M.E.; Gray, S.A.; Kim, B.J.; Garvis, S.G.; Yoon, J. Identification of the EnteropathogensCampylobacter jejuni and Campylobacter coli Based on the cadF Virulence Gene and Its Product. J. Clin. Microbiol. 1999, 37, 510-517. [CrossRef] [PubMed]

61. Konkel, M.E.; Kim, B.J.; Rivera-Amill, V.; Garvis, S.G. Bacterial secreted proteins are required for the internalization of Campylobacter jejuni into cultured mammalian cells. Mol. Microbiol. 1999, 32, 691-701. [CrossRef] [PubMed]

62. Jin, S.; Joe, A.; Lynett, J.; Hani, E.K.; Sherman, P.C.; Chan, V.L. JlpA, a novel surface-exposed lipoprotein specific to Campylobacter jejuni, mediates adherence to host epithelial cells. Mol. Microbiol. 2001, 39, 1225-1236. [CrossRef]

63. Keo, T.; Collins, J.; Kunwar, P.; Blaser, M.J.; Iovine, N.M. Campylobacter capsule and lipooligosaccharide confer resistance to serum and cationic antimicrobials. Virulence 2011, 2, 30-40. [CrossRef]

64. Lin, J.; Michel, L.O.; Zhang, Q. CmeABC Functions as a Multidrug Efflux System in Campylobacter jejuni. Antimicrob. Agents Chemother. 2002, 46, 2124-2131. [CrossRef]

65. Müller, A.; Thomas, G.H.; Horler, R.; Brannigan, J.A.; Blagova, E.; Levdikov, V.M.; Fogg, M.J.; Wilson, K.S.; Wilkinson, A.J. An ATP-binding cassette-type cysteine transporter in Campylobacter jejuni inferred from the structure of an extracytoplasmic solute receptor protein. Mol. Microbiol. 2005, 57, 143-155. [CrossRef] [PubMed]

66. Konkel, M.E.; Larson, C.L.; Flanagan, R.C. Campylobacter jejuni FlpA Binds Fibronectin and Is Required for Maximal Host Cell Adherence. J. Bacteriol. 2009, 192, 68-76. [CrossRef]

67. Fernando, U.; Biswas, D.; Allan, B.; Willson, P.; Potter, A.A. Influence of Campylobacter jejuni fliA, rpoN and flgK genes on colonization of the chicken gut. Int. J. Food Microbiol. 2007, 118, 194-200. [CrossRef] [PubMed]

68. Neal-McKinney, J.M.; Konkel, M.E. The Campylobacter jejuni CiaC virulence protein is secreted from the flagellum and delivered to the cytosol of host cells. Front. Cell. Infect. Microbiol. 2012, 2, 31. [CrossRef] [PubMed]

69. Nachamkin, I.; Yang, X.H.; Stern, N.J. Role of Campylobacter jejuni flagella as colonization factors for three-day-old chicks: Analysis with flagellar mutants. Appl. Environ. Microbiol. 1993, 58, 1269-1273. [CrossRef] [PubMed] 
70. Wassenaar, T.M.; Van Der Zeijst, B.A.M.; Ayling, R.; Newell, D.G. Colonization of chicks by motility mutants of Campylobacter jejuni demonstrates the importance of flagellin A expression. J. Gen. Microbiol. 1993, 139, 1171-1175. [CrossRef] [PubMed]

71. Liaw, J.; Hong, G.; Davies, C.; Elmi, A.; Sima, F.; Stratakos, A.; Stef, L.; Pet, I.; Hachani, A.; Corcionivoschi, N.; et al. The Campylobacter jejuni Type VI Secretion System Enhances the Oxidative Stress Response and Host Colonization. Front. Microbiol. 2019, 10, 2864. [CrossRef] [PubMed]

72. Lertpiriyapong, K.; Gamazon, E.R.; Feng, Y.; Park, D.S.; Pang, J.; Botka, G.; Graffam, M.E.; Ge, Z.; Fox, J.G. Campylobacter jejuni Type VI Secretion System: Roles in Adaptation to Deoxycholic Acid, Host Cell Adherence, Invasion, and In Vivo Colonization. PLoS ONE 2012, 7, e42842. [CrossRef]

73. Alemka, A.; Nothaft, H.; Zheng, J.; Szymanski, C.M. N-Glycosylation of Campylobacter jejuni Surface Proteins Promotes Bacterial Fitness. Infect. Immun. 2013, 81, 1674-1682. [CrossRef]

74. Karlyshev, A.V.; Everest, P.; Linton, D.; A Cawthraw, S.; Newell, D.G.; Wren, B.W. The Campylobacter jejuni general glycosylation system is important for attachment to human epithelial cells and in the colonization of chicks. Microbiology 2004, 150, 1957-1964. [CrossRef]

75. Chart, H.; Frost, J.A.; Conway, D.; Rowe, B. Outer membrane characteristics of Campylobacter jejuni grown in chickens. FEMS Microbiol. Lett. 1996, 145, 469-472. [CrossRef]

76. Godlewska, R.; Wisniewska, K.; Pietras, Z.; Jagusztyn-Krynicka, E.K. Peptidoglycan-associated lipoprotein (Pal) of Gram-negative bacteria: Function, structure, role in pathogenesis and potential application in immunoprophylaxis. FEMS Microbiol. Lett. 2009, 298, 1-11. [CrossRef] [PubMed]

77. Konkel, M.E.; A Joens, L. Adhesion to and invasion of HEp-2 cells by Campylobacter spp. Infect. Immun. 1989, 57, 2984-2990. [CrossRef]

78. Khoury, C.A.; Meinersmann, R.J. A Genetic Hybrid of the Campylobacter jejuni flaA Gene with LT-B of Escherichia coli and Assessment of the Efficacy of the Hybrid Protein as an Oral Chicken Vaccine. Avian Dis. 1995, 39, 812. [CrossRef]

79. Godlewska, R.; Kuczkowski, M.; Wyszyńska, A.; Klim, J.; Derlatka, K.; Woźniak-Biel, A.; Jagusztyn-Krynicka, E.K. Evaluation of a protective effect of in ovo delivered Campylobacter jejuni OMVs. Appl. Microbiol. Biotechnol. 2016, 100, 8855-8864. [CrossRef] [PubMed]

80. Kobierecka, P.A.; Wyszyńska, A.K.; Gubernator, J.; Kuczkowski, M.; Wiśniewski, O.; Maruszewska, M.; Wojtania, A.; Derlatka, K.E.; Adamska, I.; Godlewska, R.; et al. Chicken Anti-Campylobacter Vaccine-Comparison of Various Carriers and Routes of Immunization. Front. Microbiol. 2016, 7, 740. [CrossRef] [PubMed]

81. Chintoan-Uta, C.; Cassady-Cain, R.L.; Al-Haideri, H.; Watson, E.; Kelly, D.J.; Smith, D.G.; Sparks, N.H.; Kaiser, P.; Stevens, M.P. Superoxide dismutase SodB is a protective antigen against Campylobacter jejuni colonisation in chickens. Vaccine 2015, 33, 6206-6211. [CrossRef] [PubMed]

82. Kobierecka, P.A.; Olech, B.; Ksiazek, M.; Derlatka, K.; Adamska, I.; Majewski, P.M.; Jagusztyn-Krynicka, E.K.; Wyszynska, A.K. Cell Wall Anchoring of the Campylobacter Antigens to Lactococcus lactis. Front. Microbiol. 2016, 7, 165. [CrossRef]

83. Bennett, C.E.; Thomas, R.; Williams, M.; Zalasiewicz, J.; Edgeworth, M.; Miller, H.; Coles, B.; Foster, A.; Burton, E.J.; Marume, U. The broiler chicken as a signal of a human reconfigured biosphere. R. Soc. Open Sci. 2018, 5, 180325. [CrossRef]

84. Souillard, R.; Répérant, J.-M.; Experton, C.; Huneau-Salaun, A.; Coton, J.; Balaine, L.; Le Bouquin, S. Husbandry Practices, Health, and Welfare Status of Organic Broilers in France. Animals 2019, 9, 97. [CrossRef] [PubMed]

85. Lacharme-Lora, L.; Chaloner, G.; Gilroy, R.; Humphrey, S.; Gibbs, K.; Jopson, S.; Wright, E.; Reid, W.; Ketley, J.; Humphrey, T.; et al. B lymphocytes play a limited role in clearance of Campylobacter jejuni from the chicken intestinal tract. Sci. Rep. 2017, 7, srep45090. [CrossRef] [PubMed]

86. El-Shibiny, A.; Connerton, P.L.; Connerton, I.F. Enumeration and Diversity of Campylobacters and Bacteriophages Isolated during the Rearing Cycles of Free-Range and Organic Chickens. Appl. Environ. Microbiol. 2005, 71, 1259-1266. [CrossRef] [PubMed]

87. Pumtang-On, P.; Mahony, T.J.; Hill, R.A.; Pavic, A.; Vanniasinkam, T. Investigation of Campylobacter colonization in three Australian commercial free-range broiler farms. Poult. Sci. 2020, 100891. [CrossRef] [PubMed]

88. Sahin, O.; Luo, N.; Huang, S.; Zhang, Q. Effect of Campylobacter-Specific Maternal Antibodies on Campylobacter jejuni Colonization in Young Chickens. Appl. Environ. Microbiol. 2003, 69, 5372-5379. [CrossRef]

89. Wesley, R.D.; Lager, K.M. Overcoming maternal antibody interference by vaccination with human adenovirus 5 recombinant viruses expressing the hemagglutinin and the nucleoprotein of swine influenza virus. Veter Microbiol. 2006, 118, 67-75. [CrossRef]

90. Zhang, F.; Peng, B.; Chang, H.; Zhang, R.; Lu, F.; Wang, F.; Fang, F.; Chen, Z. Intranasal Immunization of Mice to Avoid Interference of Maternal Antibody against H5N1 Infection. PLoS ONE 2016, 11, e0157041. [CrossRef]

91. Bublot, M.; Pritchard, N.; Le Gros, F.-X.; Goutebroze, S. Use of a Vectored Vaccine against Infectious Bursal Disease of Chickens in the Face of High-Titred Maternally Derived Antibody. J. Comp. Pathol. 2007, 137, S81-S84. [CrossRef] 